\title{
WATER RESOURCES AND DATA-NETWORK ASSESSMENT OF THE MANASOTA BASIN, MANATEE AND SARASOTA COUNTIES, FLORIDA
}

U.S. GEOLOGICAL SURVEY

WATER-RESOURCES INVESTIGATIONS 82-37

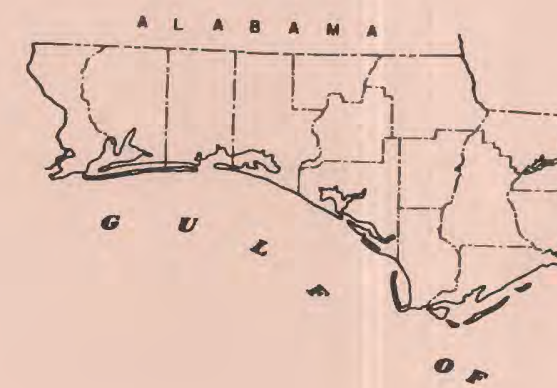

Prepared in cooperation with the

SOUTHWEST FLORIDA WATER MANAGEMENT DISTRICT 


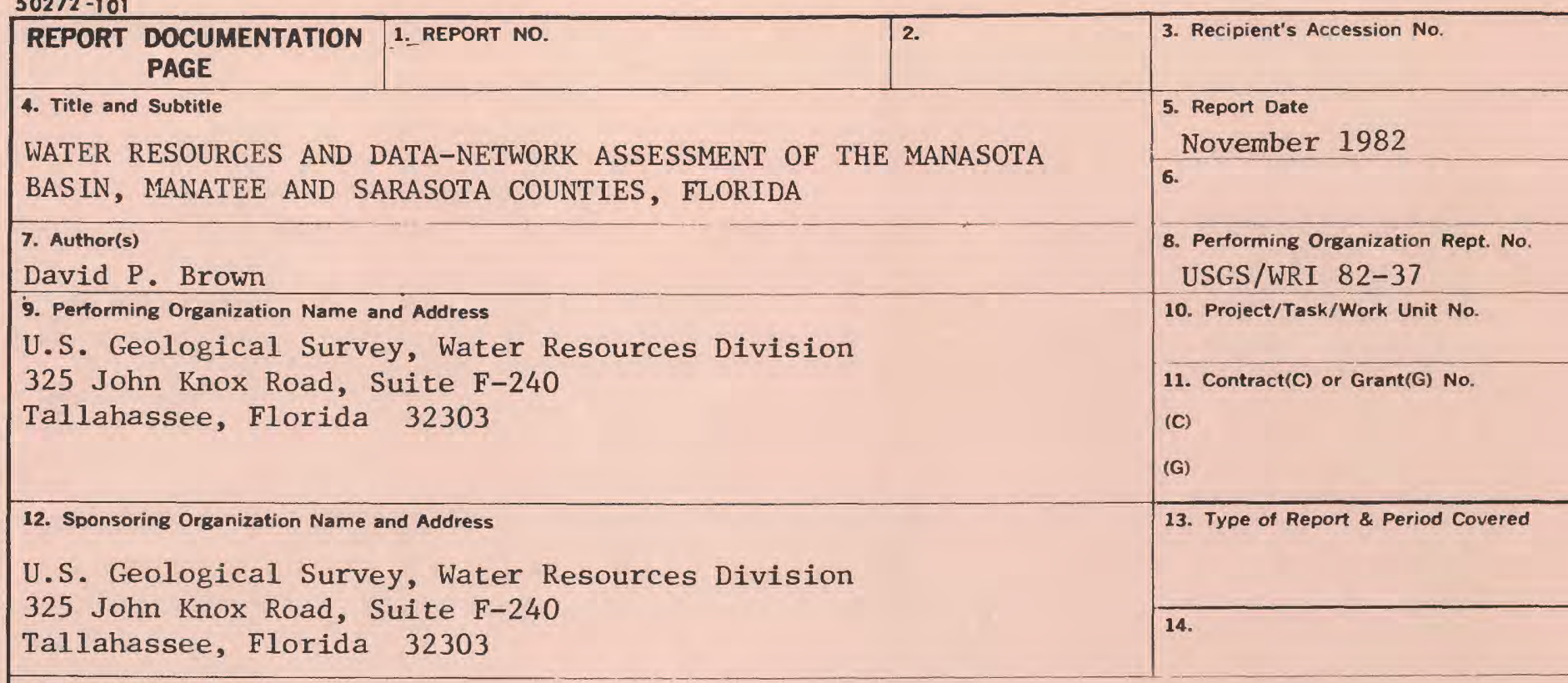

\section{Supplementary Notes}

Prepared in cooperation with the Southwest Florida Water Management District

\section{Abstract (Limit: 200 words)}

The average annual rainfall in the Manasota Basin is 53.7 inches, and annual evapotranspiration is about 39 inches. Annual runoff from gaged parts of the Basin ranges from about 13 to 17 inches per year. Streamflow in the upland areas diminishes rapidly following the end of the rainy season and approaches zero during extended dry periods.

Generally, surface water is of good quality except in tidally affected, coastal areas Its quality varies seasonally, generally becoming more mineralized during the dry season.

The principal hydrogeologic units are the surficial aquifer, the upper confining beds and minor artesian aquifers, the Floridan aquifer, and the lower confining bed. The quality of ground water is generally good except in the western and southern parts where saltwater intrusion or incomplete flushing of residual seawater has occurred.

Land-use changes and stream impoundments and diversions require reassessment of the type and use of data collected by the surface-water network. Such changes may require modification of existing sites and establishment of new ones. Development and completion of the monitoring plan could provide most of the data necessary to define groundwater system.

\section{Document Analysis a. Descriptors}

Water resource, Hydrologic data network, Ground water, Surface water, Rainfall, Water utilization, Water quality, River flow, Aquifers

\section{b. Identifiers/Open-Ended Terms}

Southwest Florida, Manasota Basin, Southwest Florida Water Management District, Manatee County, Sarasota County, Floridan aquifer, Manatee River basin, Myakka River basin, Little Manatee River basin

c. CoSATI Field/Group

18. Availability Statement

No restriction on distribution

19. Security Class (This Report)
UNCLASSIFIED
20. Security Class (This Page)
UNCLASSIFIED

21. No. of Pages

$$
87
$$

22. Price 
WATER RESOURCES AND DATA-NETWORK ASSESSMENT OF THE

MANASOTA BASIN, MANATEE AND SARASOTA COUNTIES, FLORIDA

By David P. Brown

U.S. GEOLOGICAL SURVEY

Water-Resources Investigations 82-37

Prepared in cooperation with the

SOUTHWEST FLORIDA WATER MANAGEMENT DISTRICT

Tallahassee, Florida 


\section{UNITED STATES DEPARTMENT OF THE INTERIOR \\ JAMES G. WATT, Secretary}

GEOLOGICAL SURVEY

Dallas L. Peck, Director

For additional information write to:

U.S. Geological Survey

325 John Knox Road, Suite F-240

Tallahassee, Florida 32303 


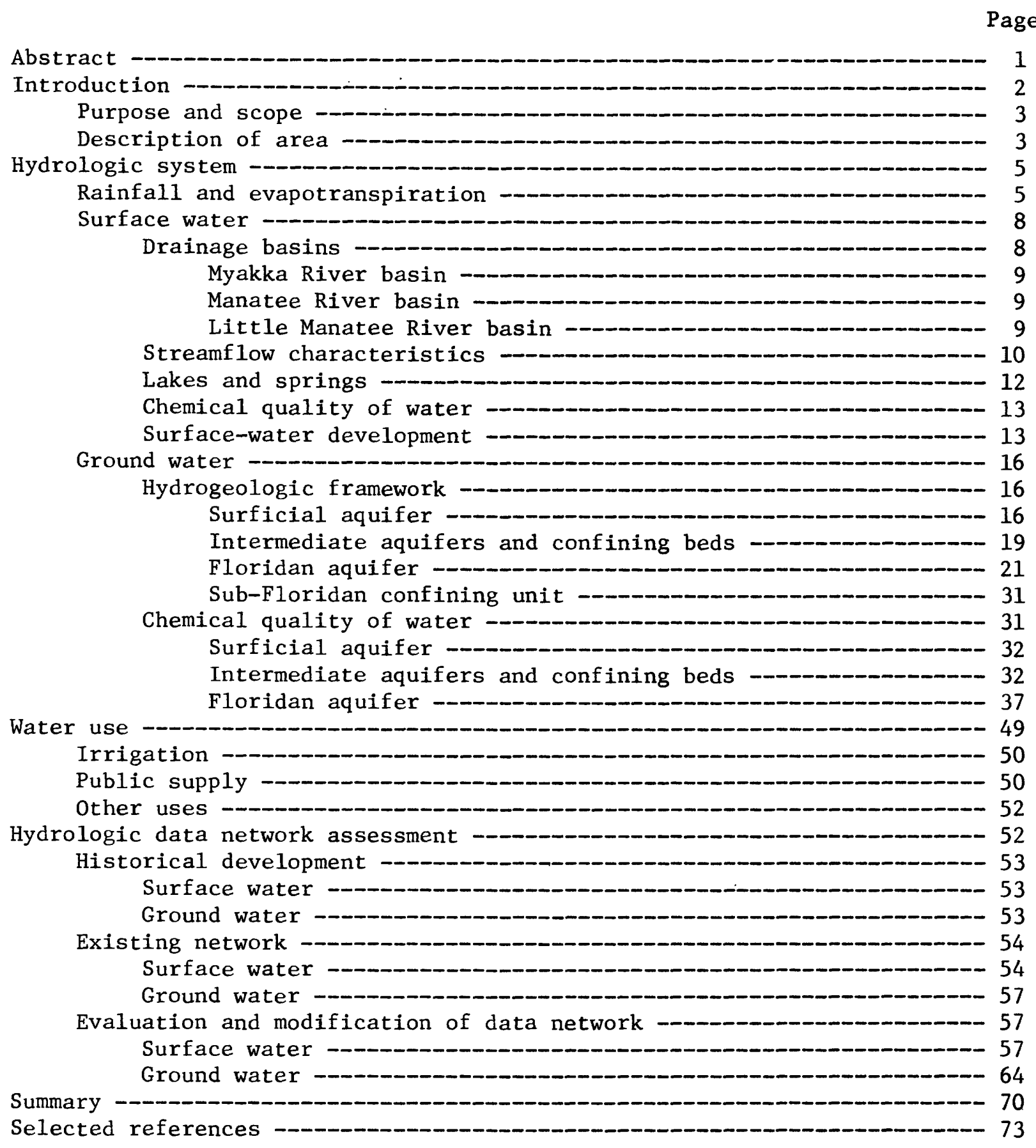

\section{ILLUSTRATIONS}

Figure 1. Map showing location of the Manasota Basin, Southwest Florida Water Management District

2. Map showing drainage basins in the Manasota Basin -_-_-_-_ 6 


\section{ILLUSTRATIONS--Continued}

Page

Figure 3. Map showing areas controlled or owned by active phosphate mining companies in and near the Manasota Basin -_-_-_- 7

4. Graph showing flow-duration curves for selected streams,

5. Graph showing seasonal variations of discharge, color, iron concentration, $\mathrm{pH}$, and specific conductance, Manatee River near Bradenton, 1964-65 - 15

6. Map showing potential impoundment sites, Manasota Basin area - 17

7. Diagram showing generalized hydrogeologic section of the Manasota Basin

8. Map showing thickness of the intermediate aquifers and confining beds overlying the Floridan aquifer

9. Hydrographs of water levels for selected wells penetrating the Tamiami-upper Hawthorn aquifer

10. Map showing altitude of the top of the Floridan aquifer - - 24

11. Hydrographs of water levels for selected wells penetrating the Floridan aquifer - 25

12-35. Maps showing--

12. Potentiometric surface of the Floridan aquifer, May 1975, and change in potentiometric surface, May 1969 to May 1975

13. Potentiometric surface of the Floridan aquifer, May 1977

14. Potentiometric surface of the Floridan aquifer, September 1977

15. Projected potentiometric surface of the Floridan aquifer, May 2000, and decline in potentiometric surface, May 1976 to May 2000

16. Projected potentiometric surface of the Floridan aquifer, October 2000, and decline in the potentiometric surface, November 1976 to October 2000

17. Chemical quality of water from wells penetrating the surficial aquifer

18. Concentrations of dissolved solids in water from wells penetrating the Tamiami-upper Hawthorn aquifer --_- 34

19. Concentrations of chloride in water from wells penetrating the Tamiami-upper Hawthorn aquifer -_-_-_- 35

20. Concentrations of sulfate in water from wells penetrating the Tamiami-upper Hawthorn aquifer - 36

21. Concentrations of dissolved solids in water from wells penetrating the upper zone of the Floridan aquifer -- 38 
Figures 12-35. , Maps showing--continued

22. Concentrations of dissolved solids in water from wells penetrating the middle zone of the Floridan aquifer - 39

23. Concentrations of dissolved solids in water from wells penetrating the lower zone of the Floridan aquifer -- 40

24. Concentrations of sulfate in water from wells penetrating the upper zone of the Floridan aquifer --_-- 41

25. Concentrations of sulfate in water from wells penetrating the middle zone of the Floridan aquifer ----- 42

26. Concentrations of sulfate in water from wells penetrating the lower zone of the Floridan aquifer

27. Concentrations of chloride in water from wells penetrating the upper zone of the Floridan aquifer

28. Concentrations of chloride in water from wells penetrating the middle zone of the Floridan aquifer

29. Concentrations of chloride in water from wells penetrating the lower zone of the Floridan aquifer ------ 46

30. Concentrations of fluoride in water from wells penetrating the middle zone of the Floridan aquifer ----- 47

31. Concentrations of fluoride in water from wells penetrating the lower zone of the Floridan aquifer --.- 48

32. Location of proposed sites and transects and regional observation monitor-well network as of 1978 -.--_-- 55

33. Observation-we11 network - 58

34. Potentiometric surface of the Floridan aquifer and water table of the surficial aquifer, Verna well field, Sarasota County, May 1978 - 59

35. Proposed surface-water data-collection network 63

TABLES

Table 1. Generalized land use, 1975, and projected land use, $2000----5$

2. Drainage areas in the Manasota Basin

3. Summary of data from stream-gaging stations in the Manasota Basin and adjacent areas through September 1977 - 10

4. Water quality of selected streams, Manasota Basin and adjacent areas -_-_-_- 14

5. Characteristics of potential impoundment sites, Manasota Basin 


\section{TABLES--Continued}

Page

Table 6. Historical and projected water use in the Manasota Basin

7. Historical and projected water use by selected utility systems

8. Surface-water data-collection sites, Manasota Basin, 1978 56

9. Framework for design of a surface-water data-collection program

10. Proposed surface-water data-collection network 65

\section{ABBREVIATIONS AND CONVERSION FACTORS}

Factors for converting inch-pound units to International System (SI) of metric units and abbreviation of units

Multiply

inch (in)

foot $(\mathrm{ft})$

mile (mi)

acre

square mile $\left(\mathrm{mi}^{2}\right)$

gallon (gal)

million gallons (Mgal)

acre foot (acre-ft)

cubic foot per second

$$
\left(\mathrm{ft}^{3} / \mathrm{s}\right)
$$

gallon per minute

(gal/min)

million gallons per day

( $\mathrm{Mgal} / \mathrm{d}$ )

foot per mile $(\mathrm{ft} / \mathrm{mi})$
By

$$
\begin{gathered}
25.4 \\
0.3048 \\
1.609 \\
4,047 \\
2.590 \\
3.785 \\
0.003785 \\
3,785 \\
1,234 \\
0.02832 \\
0.06309 \\
0.04381 \\
0.1894
\end{gathered}
$$

\section{$\underline{\text { To obtain }}$}

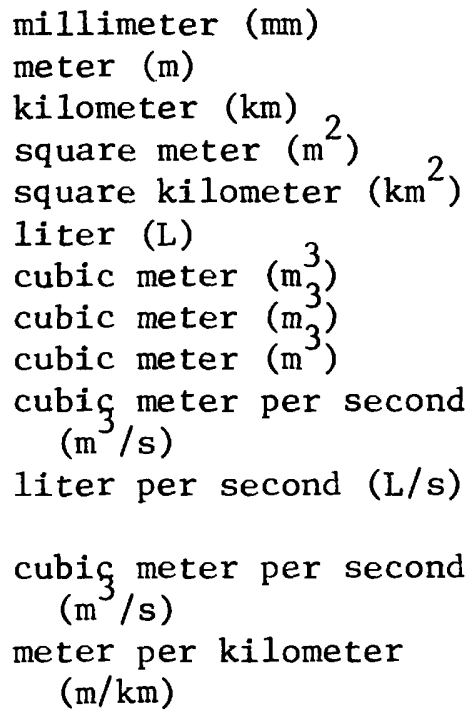

National Geodetic Vertical Datum of 1929 (NGVD of 1929).--A geodetic datum derived from a general adjustment of the first-order level nets of both the United States and Canada, formerly called "mean sea level." In the text of this report, NGVD of 1929 is referred to as sea level. 


\section{WATER RESOURCES AND DATA-NETWORK ASSESSMENT OF THE MANASOTA \\ BASIN, MANATEE AND SARASOTA COUNTIES, FLORIDA}

By David P. Brown

ABSTRACT

The source of freshwater in the Manasota Basin (hydropolitical basin) is rainfall. The average annual rainfall within the Basin is 53.7 inches, and evapotranspiration within the Southwest Florida Water Management District is about 39 inches per year.

The Myakka and Manatee Rivers are the major streams draining the Basin. Numerous small streams originate within several miles of the coast and flow into bays and estuaries. Annual runoff for gaged parts of the Myakka River and Manatee River basins ranges from about 13 to 17 inches per year. Streamflow in the upland areas of the Basin diminishes rapidly following the end of the rainy season and approaches zero during extended dry periods.

Surface water in the Basin is generally of good quality, except in tidally affected coastal areas where streams and canals are commonly saline. The quality varies seasonally, generally becoming more mineralized during the dry seasons when flow of streams is supplemented or maintained by ground-water discharge.

As of 1978, the Big Slough Canal at North Port, the Manatee River at Lake Manatee Reservoir, the Braden River at Ward Lake, and the Little Manatee River in northern Manatee County were used for public water supply, supplying about 40 million gallons per day.

The Manasota Basin is underlain by a thick sequence of sedimentary rocks whose lithology and structure control the occurrence and movement of ground water. The principal hydrologic units are (1) surficial aquifer, (2) intermediate aquifers and confining beds, (3) Floridan aquifer, and (4) sub-Floridan confining unit.

The quality of ground water in the Basin is generally good, except in the western (coastal) and southern parts where saltwater intrusion or incomplete flushing of connate water has occurred. The mineral content of ground water generally increases with depth and also increases areally from the northeast towards the west and south.

Concentrations of dissolved solids in the surficial aquifer and intermediate aquifers are generally less than 500 milligrams per liter, except in coastal areas where concentrations may exceed 5,000 milligrams per liter. In the Floridan aquifer, concentrations of dissolved solids exceed 500 milligrams per liter in the western and southern parts of the Basin. 
In the surficial aquifer and intermediate aquifers, concentrations of sulfate and chloride greater than 250 milligrams per liter occur in the coastal and southern parts of the Basin. In the Floridan aquifer, concentrations of sulfate exceeded 250 milligrams per liter, except in the northeast. Concentrations of chloride greater than 250 milligrams per liter are generally limited to the coastal and extreme southern parts of the Basin.

The intermediate aquifers and Floridan aquifer are highly developed sources of water. The surficial aquifer is undeveloped except near the coast and southern part of the Basin where water from deep aquifers is unpotable. Water from intermediate aquifers is widely used for domestic and public supplies. The Floridan aquifer is a major source of water for agricultural irrigation.

Water use in the Basin is estimated to be 118 million gallons per day. The major use of water is for irrigation, an estimated $44 \mathrm{million}$ gallons per day in 1975. More than 90 percent of the irrigation water was from ground-water sources. Estimated water use for public supply was 30.3 million gallons per day (1978) and is projected to increase to 120 million gallons per day by 2000 . By 1985 , the projected water use for industrial supply (including proposed phosphate mining in Manatee County) will be 34.4 million gallons per day.

The existing surface-water network consists of three continuous-record stage stations and three crest-stage, partial-record stations. Currently, one streamflow station, Myakka River near Sarasota, and one discontinued station, Manatee River near Bradenton, have sufficient discharge record (more than 20 years) to adequately define their streamflow characteristics. The revised network could include: (1) an expansion of the existing streamflow-data network; (2) a low-flow, partial-record network; (3) expansion of the crest-stage, partial-record network; and (4) collection of data required for modeling of stream systems. Major land-use changes, such as strip mining, urbanization, and stream impoundments and diversions, require reassessment of the type and use of data collected at each station. Such changes may require establishment of additional continuous- and partial-record stations to provide an adequate data base for management of the surface-water sources.

The major emphasis of the existing ground-water network is directed toward the Floridan aquifer; few data are being collected on the surficial aquifer or intermediate aquifers. Most wells in the network are privately owned and may penetrate one or more aquifers. or water-bearing zones. Data obtained from these wells may represent a composite of various aquifers, and access to these wells may be only temporary.

Development and completion of the regional ground-water monitoring plan could provide most of the data necessary to adequately define the ground-water system and meet the needs for appraisal, protection, and management of groundwater resources in the Basin. About 50 percent of the monitoring sites should be completed by 1982 .

\section{INTRODUCTION}

The Southwest Florida Water Management District has named the area consisting of Manatee and Sarasota Counties the "Manasota Basin." It is a hydropolitical basin that is one of the most rapidly developing areas in southwest Florida. 
Associated with the development is increased water use. Increased uses for irrigation and industry are of particular importance because the amount of water used is over twice the amount required for domestic and municipal uses. A continued increase in water use could deplete streams and lakes and the aquifers, cause or increase the rate of saltwater intrusion, and degrade the quality of ground water.

More hydrologic data for the Manasota Basin are needed to provide information necessary to wisely manage the water resources. A prerequisite to obtaining needed hydrologic information is a network of stations for collection of surface-water and ground-water data. The Manasota Basin Board of the Southwest Florida Water Management District and the U.S. Geologica1 Survey undertook a cooperative investigation to increase hydrologic information by modifying the hydrologic-data network to accommodate existing conditions and proposed waterresources development. This report evaluates the available information and proposes a program of increased data collection.

\section{Purpose and Scope}

The purpose of this study is to describe the water resources of the Manasota Basin, to evaluate the adequacy of the hydrologic data network for assessing regional effects of water-resources development, and to propose additional data collection. Specific objectives include: (1) description of the surface-water and ground-water resources, existing and potential water-resources development, and water use; (2) development of maps that delineate water quality in the multizoned aquifer system; and (3) analysis of the current hydrologic data network and recommendations for modification of the network. The description of the area's water resources and the data network evaluation are based on existing data and previously published reports.

\section{Description of Area}

The Manasota Basin, one of 10 hydropolitical basins in the Southwest Florida Water Management District, is bordered by the Gulf of Mexico on the west, the Alafia Basin on the north, and the Peace Basin on the east and south (fig. 1). The Basin is about $1,300 \mathrm{mi}^{2}$ in area.

The population of the Manasota Basin in 1977 was about 287,000 (Southwest Florida Water Management District, 1978). Nearly 40 percent of the population is in incorporated areas, generally along the Gulf Coast, one of the more rapidly growing areas in the Basin. By 1980, the population had increased to 347,700 (Southwest Florida Water Management District, written commun., 1980). Bradenton, Englewood, Palmetto, Venice, and Sarasota are the principal cities in the area.

Land surface in the Basin ranges from sea level along the coast to about 135 feet above sea level in the headwaters of the Manatee River in northeast Manatee County. The topography is largely controlled by a series of relic marine terraces (Peek, 1958a). Marshes and swamps occupy about 5 percent of the upland that lies more than 40 feet above sea leve1. 


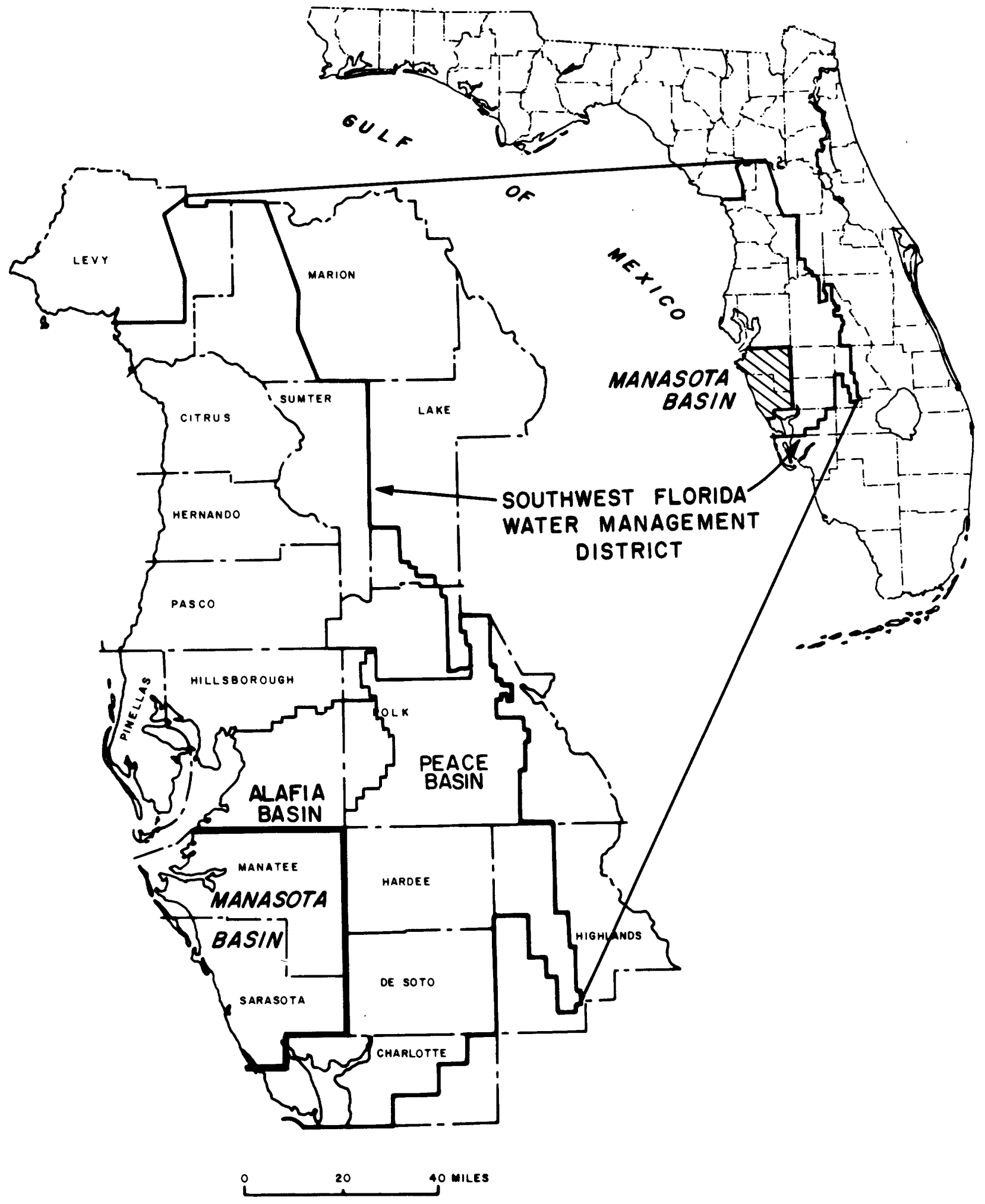

Figure 1.--Location of the Manasota Basin, Southwest Florida Water Management District. 
The Myakka and Manatee Rivers are the two major streams (fig. 2). Big Slough Canal and Braden River are the largest tributaries to the Myakka and Manatee Rivers, respectively. The Little Manatee River and the Peace River drain parts of the Manasota Basin, and numerous, small coastal streams drain low-lying coastal areas. Long, low keys that parallel the coast do not have any defined drainage channels.

The three major types of land use in the Manasota Basin in 1975 were: rangeland, about 49 percent; (2) agricultural land (cropland, pasture, and citrus groves), about 23 percent; and (3) urban, about 12 percent (table 1). Urban land occurs mostly along the coast. Projected land-use changes by the year 2000 indicate a decrease in rangeland and agricultural land and a substantial increase in urban land along the coast and southern boundary.

Transitional land, such as strip mines, quarries, and gravel pits, represented less than 4 percent of the Basin in 1975. Texas Instruments Incorporated (1977b) has projected an increase from 505 to 12,617 acres of strip mines, quarries, and gravel pits by 1985, reflecting the expected development of phosphate mining in eastern Manatee County. By 2000, strip mines, quarries, and gravel pits will have decreased to about 9,000 acres. This projection reflects an anticipated decline in phosphate mining as the areas are mined out. Figure 3 shows areas in and near the Basin controlled or owned by active phosphate mining companies.

\begin{tabular}{l|r|c|r|c}
$\begin{array}{l}\text { Table 1.--Generalized land use, 1975, and projected land use, } 2000 \\
\text { [Modified from Texas Instruments }\end{array}$ \\
\hline \multirow{4}{*}{ Land use } & \multicolumn{2}{|c|}{1975} & \multicolumn{2}{c}{2000} \\
\cline { 2 - 5 } & Acres & $\begin{array}{c}\text { Percent } \\
\text { of basin }\end{array}$ & Acres & $\begin{array}{c}\text { Percent } \\
\text { of basin }\end{array}$ \\
\hline Urban & 105,760 & 11.82 & 144,331 & 16.14 \\
Agricultural & 205,808 & 23.01 & 187,447 & 20.96 \\
Rangeland & 437,887 & 48.98 & 425,481 & 47.58 \\
Forest & 40,375 & 4.51 & 39,768 & 4.45 \\
Wetland & 55,224 & 6.18 & 53,998 & 6.04 \\
Transitional & 32,653 & 3.65 & 26,682 & 2.98 \\
Water & 16,548 & 1.85 & 16,548 & 1.85 \\
Total & 894,255 & 100 & 894,255 & 100 \\
\hline
\end{tabular}

\section{HYDROLOGIC SYSTEM}

\section{$\underline{\text { Rainfall and Evapotranspiration }}$}

Rainfall is the source of freshwater in the Manasota Basin. Part of the rainfall remains on the surface, collecting in topographic depressions, such as lakes, swamps, and marshes, or entering stream channels and flowing out of 


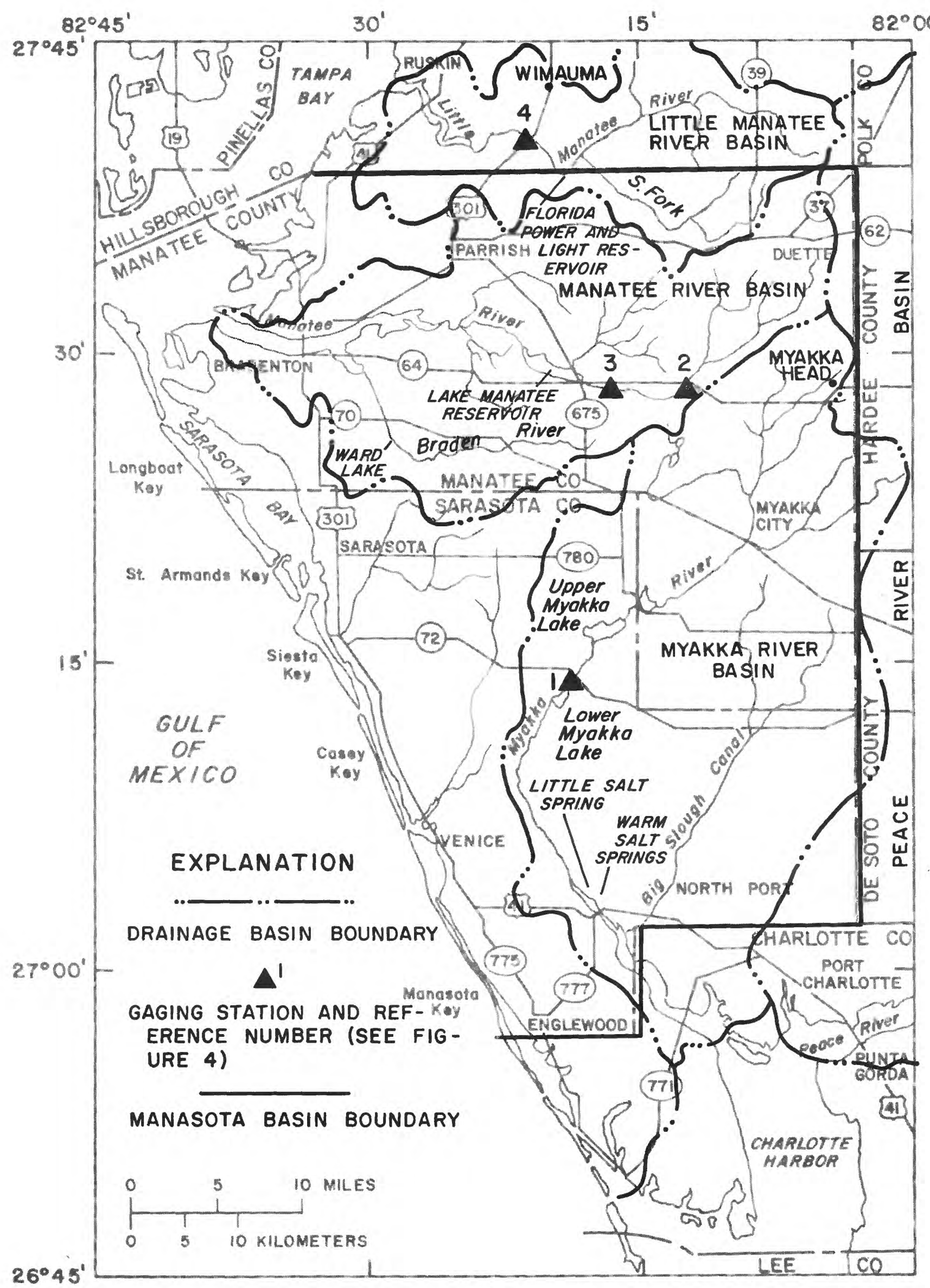

Figure 2.--Drainage basins in the Manasota Basin. 


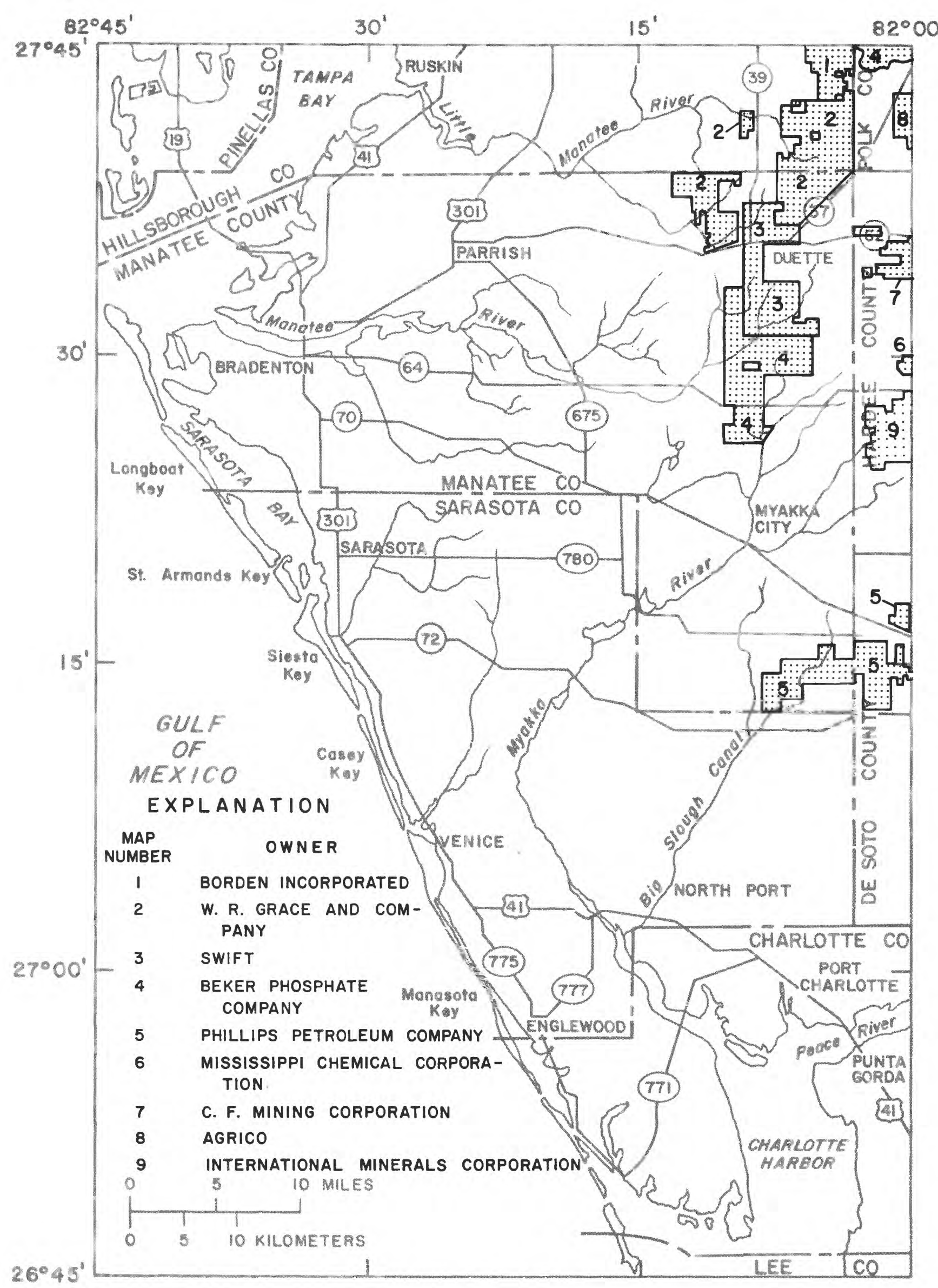

Figure 3.--Areas controlled or owned by active phosphate mining companies in and near the Manasota Basin (from Texas Instruments Incorporated, 1977b). 
the area. The remainder is lost to evapotranspiration or infiltrates downward into the soil and aquifers. Water that infiltrates into the soil and aquifers may return to the surface within a few years as seepage, spring flow, or until pumped, the water may remain in storage for thousands of years.

The long-term average annual rainfall within the Basin is 53.7 inches. The average annual rainfall for 1956 through 1975 ranged from less than 52 inches in the south to more than 56 inches in the central part of the Basin. About 60 percent of the rainfall occurs from June through September as a result of heavy rains generally associated with convective thunderstorms. Rainfall during this period ranges from 5 to 8 inches per month. About 40 percent of the rainfall occurs from October through May, ranging from about 1.5 to 3 inches per month.

The evapotranspiration rate within the Manasota Basin has been determined to be about 39 inches per year (Southwest Florida Water Management District, 1978). About 60 percent of this occurs from May to October. Average annual evapotranspiration of the Myakka River basin was estimated to be 35 to 40 inches (Joyner and Sutcliffe, 1976); average annual lake evaporation was estimated to be 52 inches. Joyner and Sutcliffe (1976) reported that evapotranspiration losses from the numerous, predominantly wet-weather, vegetation-filled ponds in the Myakka River basin probably exceed 60 inches per year.

\section{Surface Water}

Drainage Basins

Boundaries of major drainage basins are delineated in figure 2, and areas are given in table 2. The major basins are the Myakka and Manatee. The Little Manatee River drains the extreme northern part of the Manasota Basin. The Peace River drains small sections along the eastern and southern boundaries of the Basin.

Numerous small streams drain coastal areas between the Myakka and Manatee Rivers and Tampa Bay. These streams are tidally affected throughout much of their length and are of little importance as sources of water.

Table 2.--Drainage areas in the Manasota Basin

\begin{tabular}{l|r|c}
\hline \multirow{2}{*}{ Drainage basin } & \multicolumn{2}{|c}{$\begin{array}{c}\text { Drainage area } \\
\left(\mathrm{mi}^{2}\right)\end{array}$} \\
\cline { 2 - 3 } & Total & $\begin{array}{c}\text { Manasota Basin } \\
\text { (approximate) }\end{array}$ \\
\hline Peace River basin & 2,403 & 76 \\
Myakka River basin & 550 & 475 \\
Coastal area between Myakka & 425 & 374 \\
and Manatee Rivers & 357 & 356 \\
Manatee River basin & 211 & 72 \\
Little Manatee River basin & 877 & 42 \\
Tampa Bay and coastal areas & & \\
\hline
\end{tabular}


The larger streams and canals of the Myakka River basin are shown in figure 2. The natural stream channels form a poorly developed drainage system with large swampy areas bordering many channels. In broad flatlands, most natural drainageways are shallow sloughs that range in width from a few feet to more than a mile. Only the Myakka River channel is well defined and naturally entrenched throughout its course. Many sloughs and swampy areas have been drained by ditches and canals.

The Myakka River rises in the northeastern part of the Manasota Basin and flows southward to the Gulf of Mexico. The river is 69 miles long and drains $550 \mathrm{mi}^{2}$. At its source, the channel is about 115 feet above sea level. In the upper reach, the channel has a fairly steep gradient, about $5 \mathrm{ft} / \mathrm{mi}$, in comparison to the lower reaches where the channel gradient is generally less than 1 $\mathrm{ft} / \mathrm{mi}$.

Big Slough Canal drains the southeastern part of the Myakka River basin. The canal drains flat, swampy lowlands that are generally less than 50 feet above sea level.

\section{Manatee River basin}

The Manatee River and its principal tributary, the Braden River, drain about $356 \mathrm{mi}^{2}$ of the Manasota Basin (table 2 and fig. 2). The eastern part of the basin consists of relatively flat terraces that are poorly drained and contain numerous small shallow lakes and swamps. A network of canals has been dug within the Basin to augment natural drainage.

The Manatee River rises in the northeastern part of the Manasota Basin and flows generally westward to the Gulf of Mexico. The river is about 53 miles long and, at its source, is about 130 feet above sea level. In the upper reaches, the river channel has a relatively steep gradient, about $5 \mathrm{ft} / \mathrm{mi}$, compared to the lower reaches where the gradient is less than $1 \mathrm{ft} / \mathrm{mi}$. The stream is affected by tides more than 20 miles upstream from the Gulf of Mexico.

The Braden River rises in the central part of the Manasota Basin and flows west and north to the Manatee River. The river drains about $86 \mathrm{mi}^{2}$, is about 23 miles long, and, at its source, is about 75 feet above sea level.

\section{Little Manatee River basin}

The Little Manatee River is about 39 miles long, heads in southeastern Hillsborough County, and flows westward into Tampa Bay (fig. 2). The stream drains about $72 \mathrm{mi}^{2}$ of the northern part of the Manasota Basin. At its source, the channel is about 100 feet in altitude and has a fairly steep gradient. In the lower reach of the river, the stage rises and falls with the tides in Tampa Bay. During low flow, tidal effects are discernible as much as 15 miles from the mouth. 
The South Fork Little Manatee River, the largest tributary, is about 14 miles long and heads in northeastern Manatee County (fig. 2). It drains about $40 \mathrm{mi}^{2}$ in Manatee County and about $1 \mathrm{mi}^{2}$ in Hillsborough County.

\section{Streamflow Characteristics}

The average, maximum, and minimum discharges of gaged streams in the Manasota Basin and adjacent areas are presented in table 3. Streamflow characteristics reflect climatic conditions, hydraulic characteristics of the surficial aquifer, and topography; they may be used to evaluate the stream's dependability for water supply.

Table 3.--Summary of data from stream-gaging stations in the Manasota Basin and adjacent areas through September 1977

\begin{tabular}{|c|c|c|c|c|c|c|c|}
\hline & Station name & Years of & Drainage & & $\begin{array}{l}\text { Discharg } \\
\left(\mathrm{ft}^{3} / \mathrm{s}\right)\end{array}$ & & Runoff \\
\hline & & & & Average & Maximum & Minimum & \\
\hline (1) & $\begin{array}{l}\text { Myakka River } \\
\text { near Sarasota }\end{array}$ & 41 & 229 & 253 & 8,670 & No flow & 15.00 \\
\hline (2) & $\begin{array}{l}\text { Manatee River } \\
\text { near Myakka Head }\end{array}$ & 11 & 65.3 & 63.6 & 3,130 & No flow & 13.23 \\
\hline (3) & $\begin{array}{l}\text { Manatee River } \\
\text { near Bradenton }\end{array}$ & $26^{1 /}$ & 87.1 & 109 & 3,440 & 1.7 & 16.99 \\
\hline (4) & $\begin{array}{l}\text { Little Manatee } \\
\text { River near } \\
\text { Wimauma }\end{array}$ & 37 & 149 & 170 & 14,000 & 1.2 & 15.49 \\
\hline
\end{tabular}

1/ Period of record - April 1939 to May 1965.

Flow-duration curves are cumulative frequency curves that show the percent of time specified discharges were equaled or exceeded during a given period. Flow-duration curves at four gaging stations in the area are presented in figure 4. The curve for Myakka River has a steep slope indicating highly variable flow (Flippo and Joyner, 1968). Curves for the Manatee and Little Manatee Rivers generally decrease in slope in the low-flow range, indicating release of ground water from storage. Flow-duration curves for all streams in the Basin generally flatten out at their upper ends. The flattening out of the curves, in part, indicates detention and slow release of water from storage in the numerous lakes and swamps at high flows.

The minimum-annual-flow characteristics of streams determine their dependability for water supply. Periods of minimum flow are primarily determined by climatic conditions. Lowest base flow, streamflow that is maintained primarily from ground-water discharge, usually occurs in April or May and in November or December. 


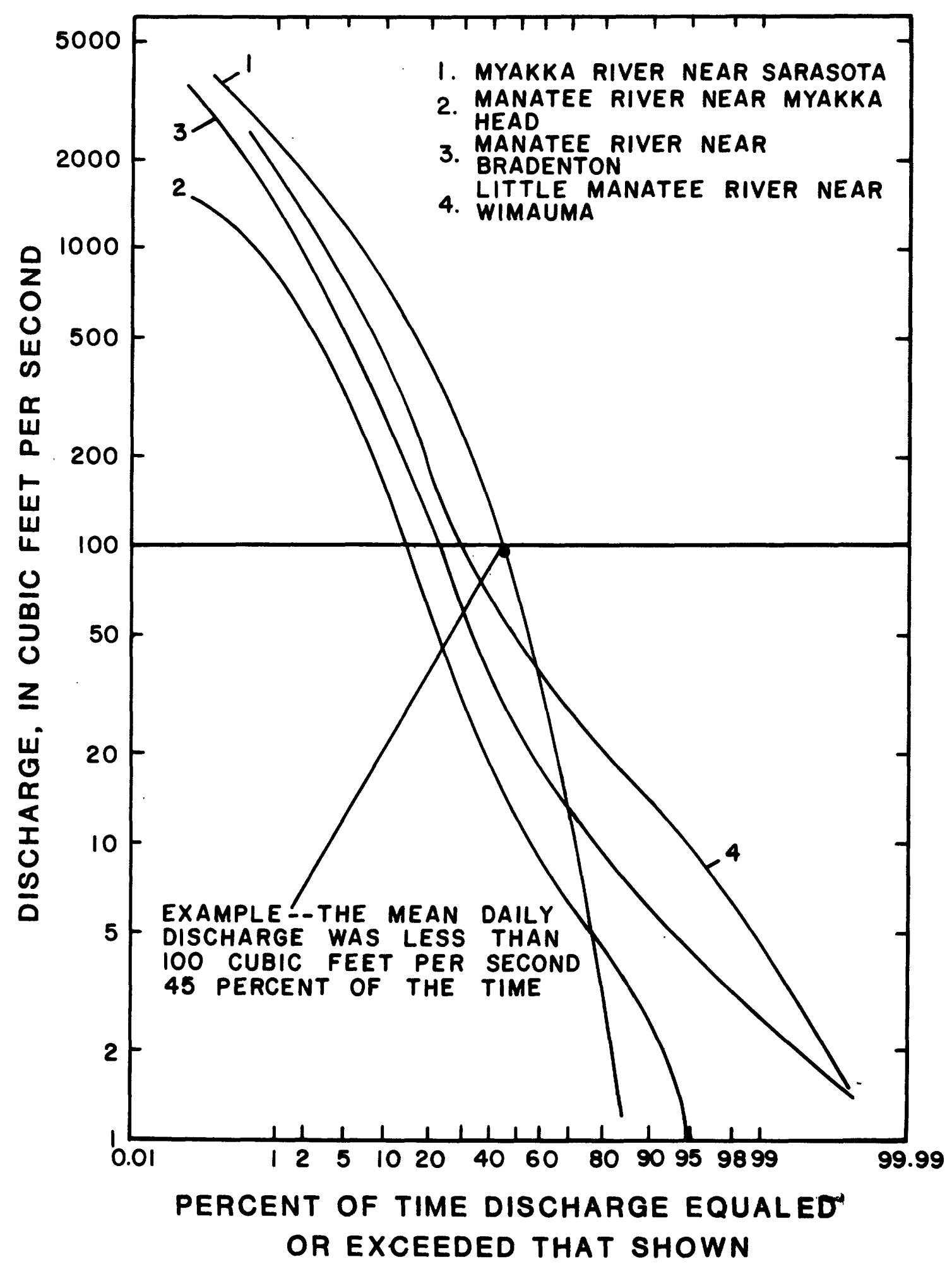

Figure 4.--Flow-duration curves for selected streams, Manasota Basin area. 
Surficial sediments are the principal contributors to base flow. They are porous and permeable and drain rapidly on the upland ridges and knolls, but are less permeable over the broad, flat areas. Streamflow in the upland areas diminishes rapidly at the end of the rainy season and approaches zero during extended periods of little or no rainfall. The less permeable surficial sediments in the relatively flat terraces and a lack of well developed drainage retard the movement of water out of these areas.

In the Myakka River basin, some runoff collects in a broad, flat, swampy area just north of Myakka City and is lost to evapotranspiration. Similar losses to evapotranspiration in the Tatum Sawgrass (marsh), in the Upper and Lower Myakka Lakes, and in marshes and swamps between the lakes cause flow from the lakes to cease most years during the dry season (Flippo and Joyner, 1968).

In the central and northern part of the Basin, low flow of the Manatee River near Bradenton and Little Manatee River near Wimauma is sustained by slow drainage of ground water from moderately to poorly permeable surficial sediments. Deep entrenchment of river channels into these sediments permits drainage to the streams from a greater thickness of the surficial material than would occur if the channels were shallower.

Much of the low flow in the coastal streams is derived from drainage from irrigation wells tapping the deep aquifers and not solely from drainage of surficial deposits (Flippo and Joyner, 1968). Drainage from irrigated land is at times an appreciable part of low flow of streams in the Manasota Basin.

\section{Lakes and Springs}

The principal natural lakes in the Manasota Basin are the Upper and Lower Myakka Lakes. Both lakes are in the Myakka River basin and occupy shallow depressions (fig. 2). The two lakes have been considered for use as public water supplies. Water storage in the lakes totals about $1,500 \mathrm{Mgal}$ at lake levels of 14 feet above sea level in the upper lake and 10 feet in the lower lake (Flippo and Joyner, 1968).

The Basin also contains hundreds of small lakes and ponds that have surface areas of less than 200 acres. Most lakes are in the western half of the Basin. Most are shallow and may go dry during moderate droughts.

The discharge of the Manatee River at Lake Manatee Reservoir, about 29 miles upstream from the river mouth (fig. 2), is regylated by an earthen dam. Lake Manatee Reservoir has a drainage area of $123 \mathrm{mi}^{2}$. At maximum pool altitude of 40 feet above sea level, the reservoir has a surface area of about 1,850 acres and a storage capacity of about 7,000 Mgal.

Ward Lake on the Braden River has a surface area of 57.6 acres and a drainage area of $59.5 \mathrm{mi}^{2}$. The crest elevation of the central control structure is about 4.2 feet above sea level. The storage capacity of the reservoir is about 58.5 Mgal (Smith and Gillespie Engineers, Inc., 1971).

Florida Power and Light's cooling reservoir on the Little Manatee River covers about 4,000 acres in northern Manatee County and has a volume of 14,300 Mga1. Water for the reservoir is taken from the Little Manatee River where the river meanders into Manatee County. 
The two principal springs in the Manasota Basin are Warm Salt and Little Salt Springs. Warm Salt Spring is in Sarasota County, 5 miles northwest of North Port. The spring head is a pool about 250 feet in diameter and 167 feet deep (Ferguson and others, 1947). The spring discharges to a tributary of the Myakka River at a rate of about $10 \mathrm{ft}^{3} / \mathrm{s}$. Little Salt Spring is 2.0 miles northeast of Warm Salt Spring. The spring discharges into a circular pool about 250 feet in diameter. Discharge measured between April 1946 (Ferguson and others, 1947) and June 1962 ranged from 0.89 to $1.53 \mathrm{ft} / \mathrm{s}$. Both springs discharge highly mineralized water.

\section{Chemical Quality of Water}

The quality of surface water in the Manasota Basin is presented in table 4. Surface water is generally suitable for most uses; however, the quality varies seasonally. During the wet season, when streamflow is mainly surface runoff, specific conductance is lowest (fig. 5) and color is highest. During the dry season, when streamflow is maintained by ground-water discharge, specific conductance increases and color decreases. Dissolved mineral concentrations of many streams in the area are increased by agricultural runoff of moderately to highly mineralized water pumped from deep aquifers.

Surface water at low flow within the Manasota Basin ranges from a calcium and magnesium bicarbonate type in the middle and upper reaches of streams to a sodium chloride or calcium and magnesium sulfate type in the low-lying areas near the coast (Kaufman, 1972). The calcium and magnesium bicarbonate type water generally occurs in carbonate rocks that underlie the Basin. This type of water may also be derived from agricultural runoff where irrigation water is pumped from a carbonate aquifer. Calcium and magnesium sulfate type water may also be derived from agricultural runoff of irrigation water pumped from deep aquifers. Sodium chloride type water occurs in low-lying, coastal areas of tidal and estuarine environments, agricultural runoff, and discharge from saline aquifers.

\section{Surface-Water Development}

Big Slough Canal at North Port, Manatee River at Lake Manatee Reservoir, and the Braden River at Ward Lake are being used (1978) as public water supplies (fig. 3). Part of the flow of the Little Manatee River in northern Manatee County is diverted for makeup water for a thermoelectric powerplant cooling reservoir. Numerous small streams, lakes, and manmade ponds are used for stock watering and irrigation.

Discharge of Big Slough Canal is controlled by a dam near the U.S. Highway 41 bridge at North Port. In 1975, an estimated $1.0 \mathrm{Mgal} / \mathrm{d}$ from Big Slough Canal was supplied to North Port. In 1977, Manatee County utility system pumped an average of $19.1 \mathrm{Mgal} / \mathrm{d}$ from Lake Manatee Reservoir. The peak daily pumpage was $27.6 \mathrm{Mgal} / \mathrm{d}$. In 1977, the average daily pumpage by the city of Bradenton from Ward Lake reservoir was $4.0 \mathrm{Mgal}$. The peak daily pumpage was $5.25 \mathrm{Mgal}$. 


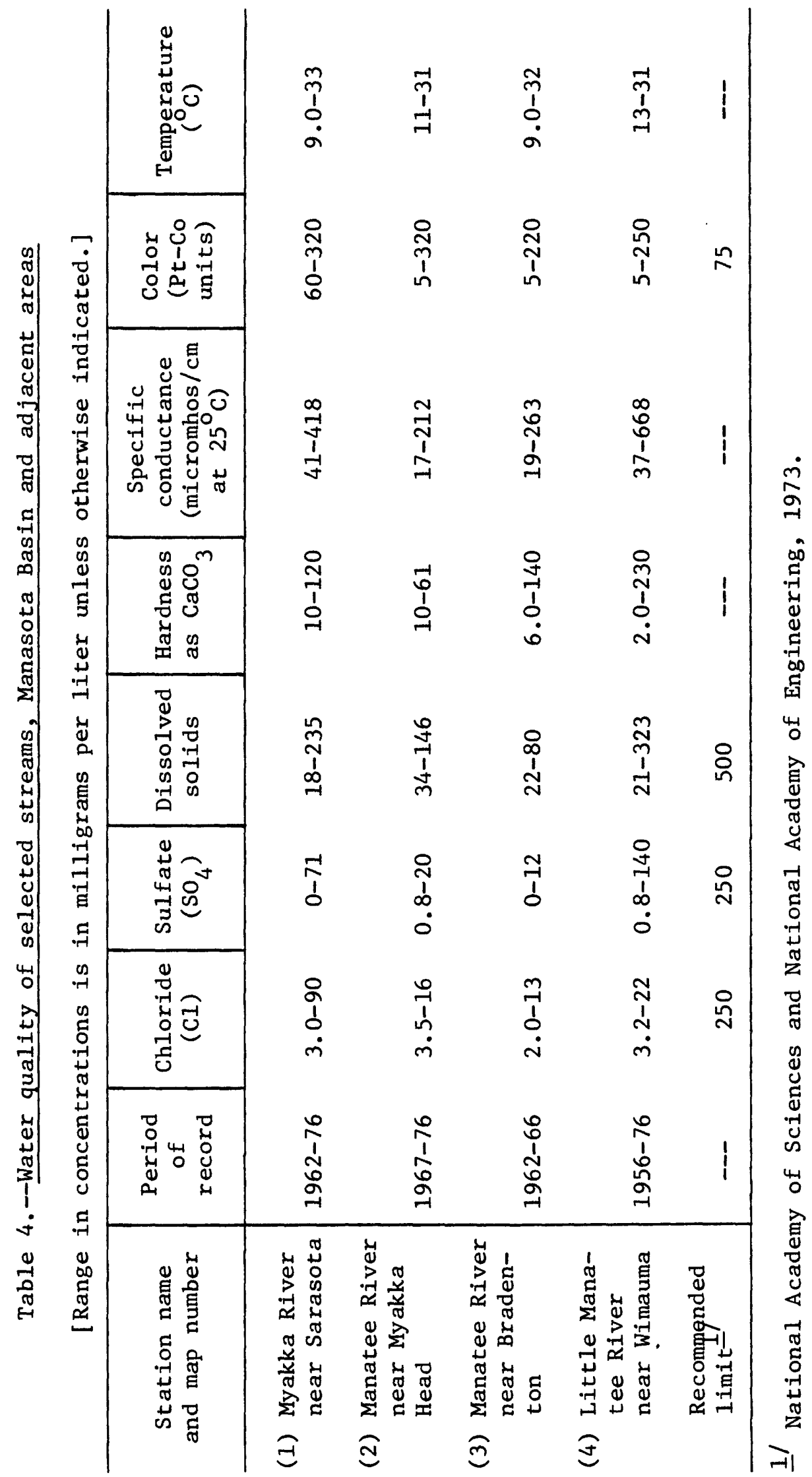




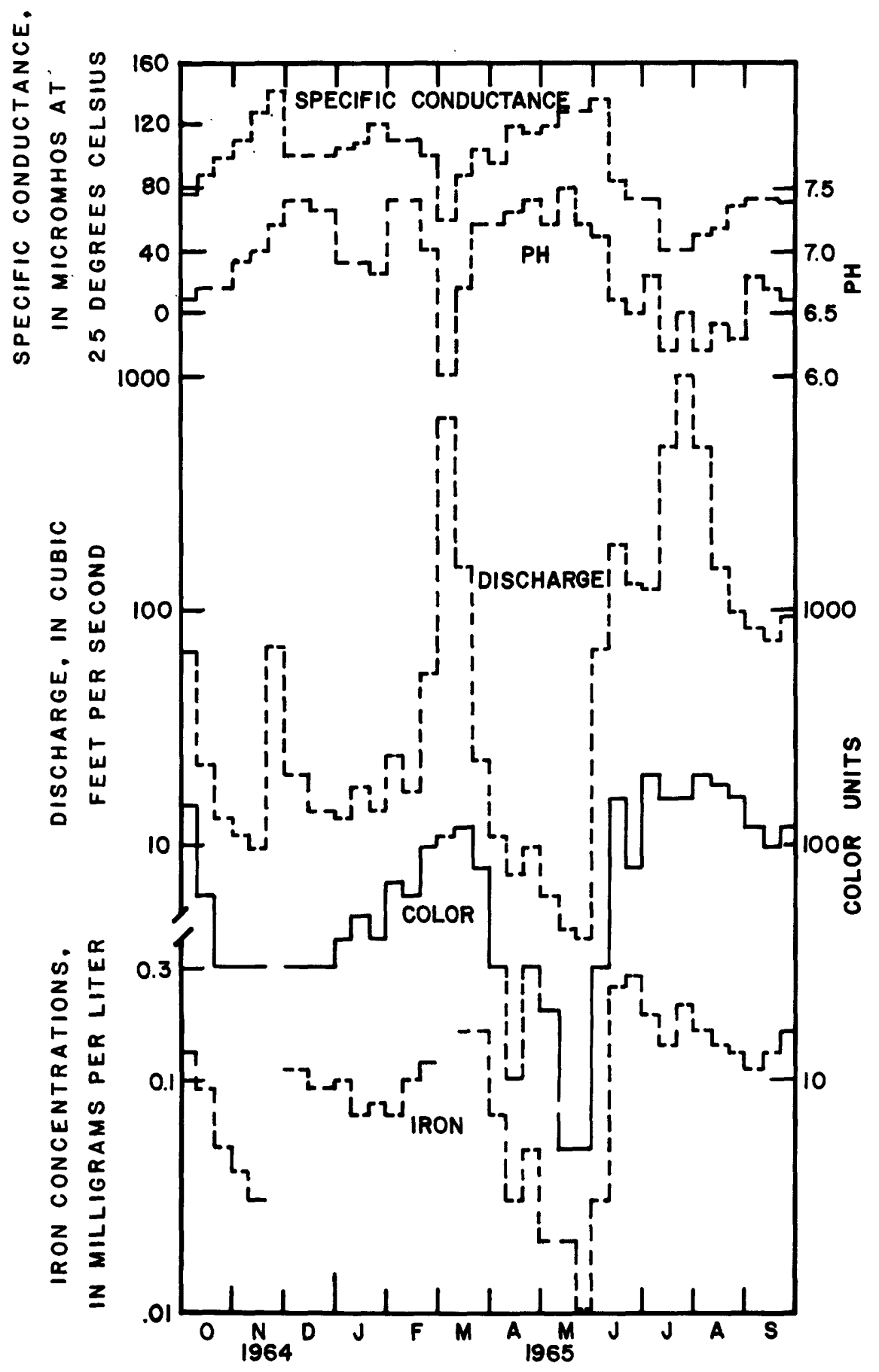

Figure 5.--Seasonal variations of discharge, color, iron concentration, $\mathrm{pH}$, and specific conductance, Manatee River near Bradenton, 1964-65 (from Kaufman, 1969). 
Water for the Florida Power and Light cooling reservoir is taken from the Little Manatee River on the basis of discharge; the greater the discharge, the greater the amount of water that can be diverted to the cooling reservoir. An estimated average of $9.8 \mathrm{Mgal} / \mathrm{d}$ is diverted (A. D. Duerr, written commun., 1979).

Additional potential impoundment sites in the Manasota Basin are shown in figure 6. The approximate drainage area, surface area, and storage capacity at selected elevations of these potential impoundment sites are listed in table 5 .

Table 5.--Characteristics of potential impoundment sites, Manasota Basin

[from U.S. Department of Agriculture, 1965]

\begin{tabular}{c|c|c|c|c}
\hline $\begin{array}{c}\text { Impoundment } \\
\text { number } \\
\text { (see fig. 6) }\end{array}$ & $\begin{array}{c}\text { Drainage } \\
\text { area } \\
\left(\mathrm{mi}^{2}\right)\end{array}$ & $\begin{array}{c}\text { Elevation } \\
\text { (ft) }\end{array}$ & $\begin{array}{c}\text { Surface } \\
\text { area } \\
\text { (acres) }\end{array}$ & $\begin{array}{c}\text { Storage } \\
\text { capacity } \\
\text { (Mgal) }\end{array}$ \\
\hline 1 & 26 & 60 & 280 & 520 \\
2 & 15 & 100 & 180 & 260 \\
3 & 17 & 95 & 380 & 750 \\
4 & 62 & 75 & 880 & 2,220 \\
5 & 139 & 40 & 2,030 & 6,590 \\
6 & 28 & 75 & 360 & 1,040 \\
7 & 16 & 95 & 250 & 550 \\
\hline
\end{tabular}

\section{Ground Water}

Hydrogeologic Framework

The Manasota Basin is underlain by a thick sequence of sedimentary rocks whose lithology and structure control the occurrence and movement of ground water. The principal hydrogeologic units are (1) surficial aquifer, (2) intermediate aquifers and confining beds, (3) Floridan aquifer, and (4) sub-Floridan confining unit (fig. 7).

\section{Surficial aquifer}

Unconfined ground water generally occurs in surficial deposits of sand, gravel, shell, and limestone. These deposits are discontinuous and result in a surficial aquifer of variable thickness and permeability. The surficial deposits consist of the Holocene sediments, Pleistocene terrace deposits, Caloosahatchee Marl, and Bone Valley Formation. 


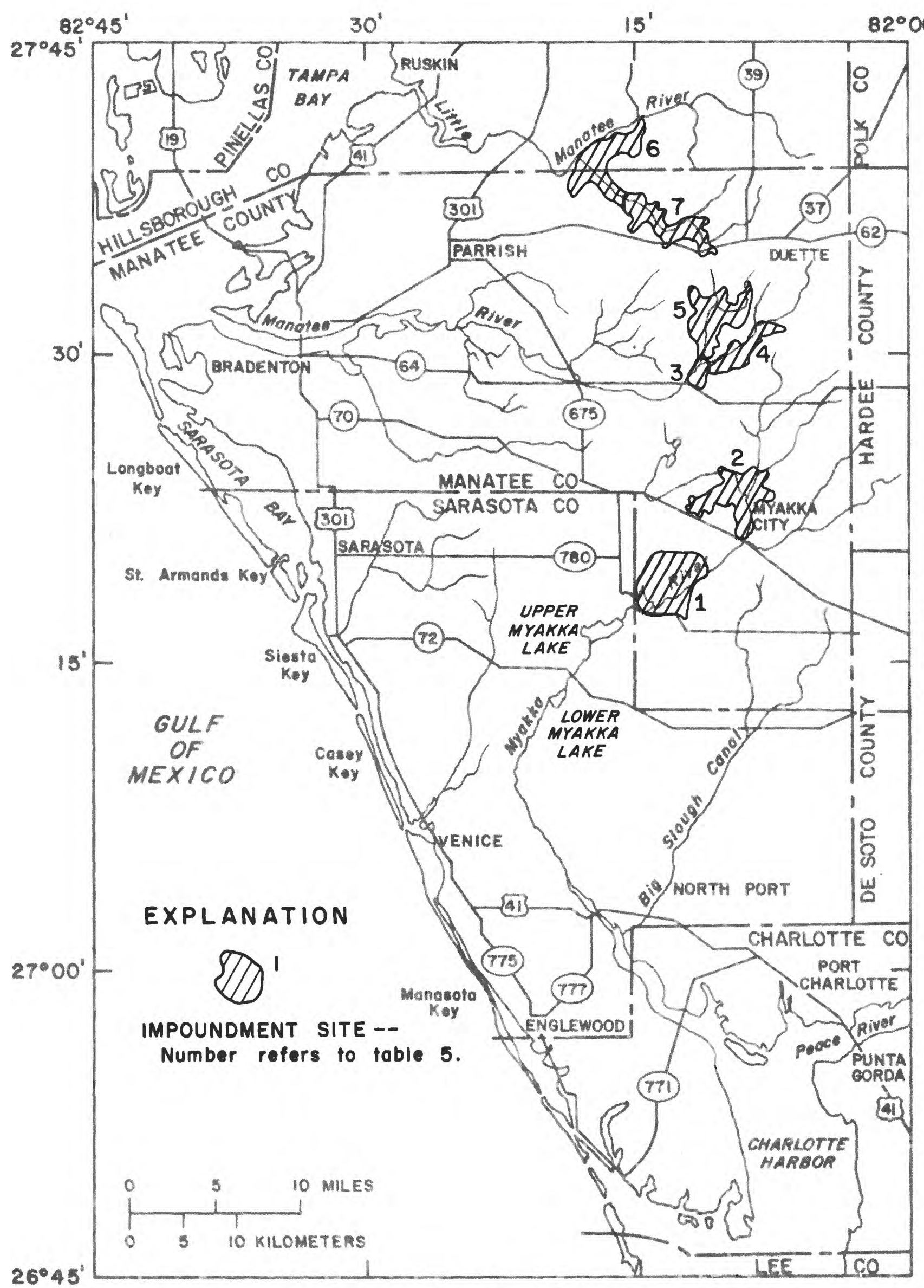

Figure 6.--Potential impoundment sites, Manasota Basin area. 


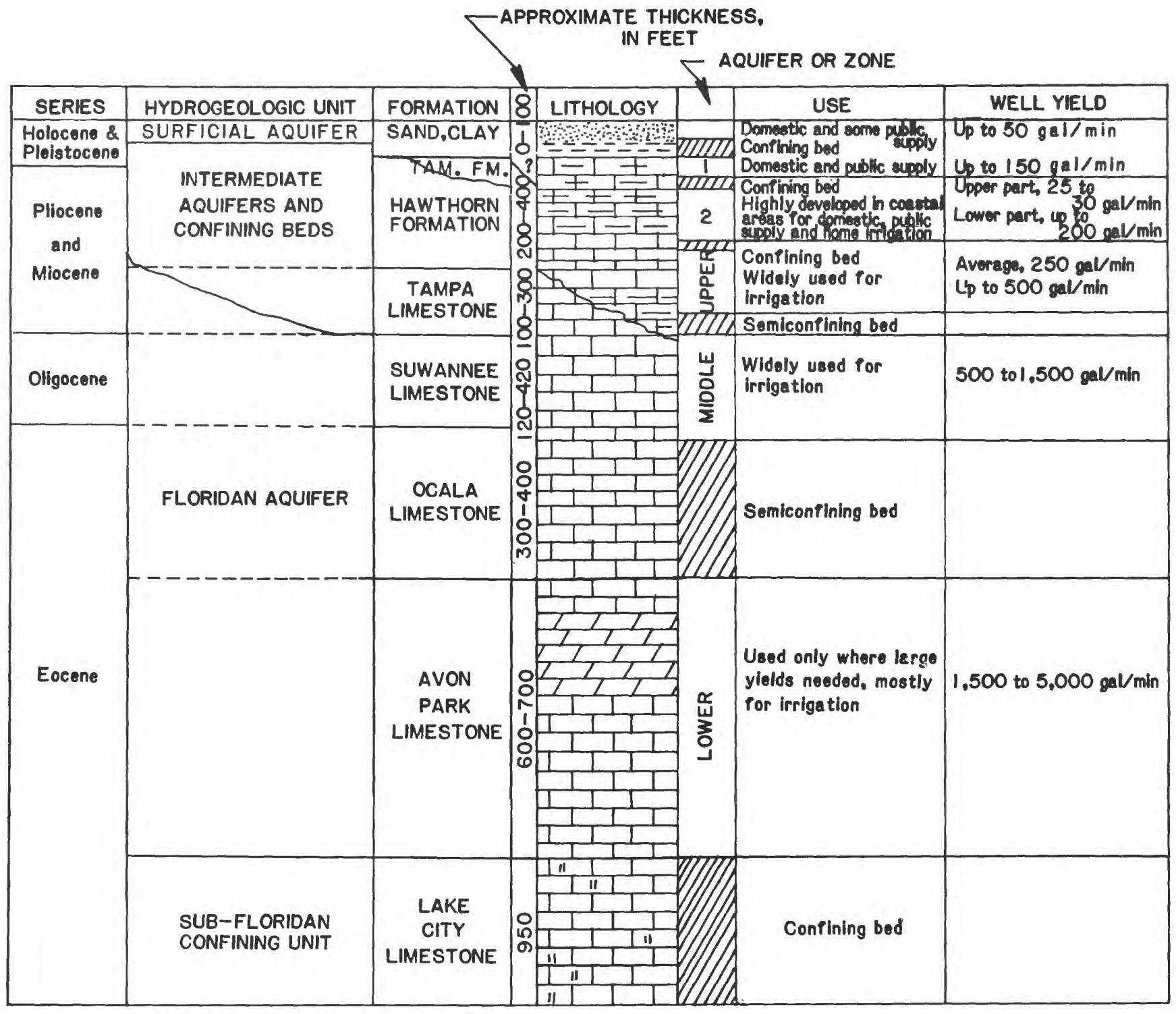

1. TAMIAMI-UPPER HAWTHORN AQUIFER

2. LOWER HAWTHORN-TAMPA AQUIFER

Figure 7.--Generalized hydrogeologic section of the Manasota Basin. 
Characteristics of the surficial aquifer vary greatly. In the northeastern part of the Basin, the aquifer consists mostly of medium to fine-grained, wellsorted quartz sand and phosphate gravel and ranges in thickness from about 10 to 60 feet. In the western and southern parts, the aquifer consists of sand, sandy limestone, and shell fragments and ranges from about 1 to 20 feet in thickness.

Water levels in the surficial aquifer range from near land surface in coastal and low-lying areas to 10 feet or more below land surface in higher areas. In flat, poorly-drained areas, average depth to the water level is less than 3 feet. Seasonal fluctuations of water levels are generally less than 5 feet. Water levels are generally lowest in April or May and highest in September.

The direction of ground-water flow is generally west and south. The configuration of the potentiometric surface in the surficial aquifer is similar to that of the land surface. The potentiometric surface is at or near sea level along the coastal area and increases to altitudes of about 130 feet in the northeastern part of the Basin.

The surficial aquifer is used as a source of water near the coast and the southern parts of the Basin where water from the deeper aquifers is not potable. Elsewhere, the surficial aquifer is generally not used as a source of water. Water from the surficial aquifer is primarily used for domestic supplies, home irrigation, and watering stock; however, several public supplies in the southern part of the Basin (Sarasota County) obtain some water from the surficial aquifer.

Most wells that penetrate the surficial aquifer are small-diameter, drivepoint wells. A few wells, 3 to 4 inches in diameter, are completed with open end and yield as much as $50 \mathrm{gal} / \mathrm{min}$.

Intermediate aquifers and confining beds

Intermediate confining beds that overlie the Floridan aquifer consist of sandy clay, clay, and marl at the base of the surficial aquifer, the Tamiami Formation, and the Hawthorn Formation. In the eastern part of Manatee County and adjacent areas, the sand and clay within the Tampa Limestone (Wilson, 1975) are included in the intermediate confining beds.

The intermediate confining beds retard vertical movement of ground water between the surficial and the Floridan aquifers. The thickness of the intermediate aquifers and confining beds ranges from about 200 feet in the northern part of the Basin to more than 400 feet in the mid-coastal and southern parts (fig. 8).

Intermediate aquifers occur within the intermediate confining beds. The aquifers consist of discontinuous permeable sand, gravel, shell, and limestone and dolomite beds in the Tamiami Formation, the upper and lower parts of the Hawthorn Formation, and the Tampa Limestone where it is in hydrologic contact with the Hawthorn Formation. Within the Basin, the intermediate aquifers contain the Tamiami-upper Hawthorn aquifer and the lower Hawthorn-Tampa aquifer.

The Tamiami-upper Hawthorn aquifer consists of permeable limestone and dolomite beds usually in the lower part of the Tamiami Formation and in the upper part of the Hawthorn Formation. These beds occur at depths ranging from 


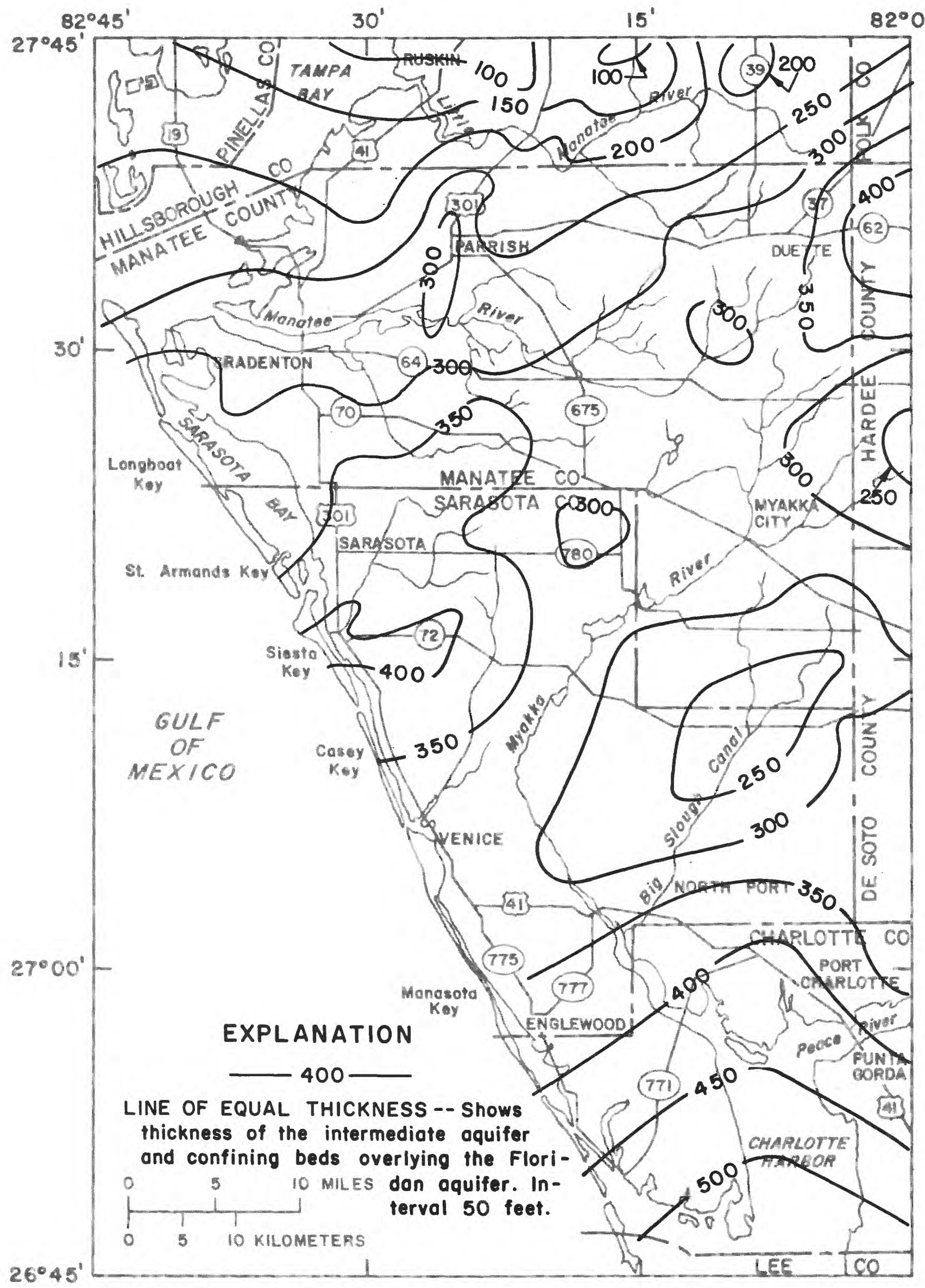

Figure 8.--Thickness of the intermediate aquifers and confining beds overlying the Floridan aquifer (modified from Buono and others, 1979). 
about 75 to 200 feet below land surface. The Tamiami Formation underlies the coastal area from Sarasota southward and extends inland 10 to $12 \mathrm{miles,} \mathrm{while}$ the Hawthorn Formation underlies the entire Manasota Basin. The aquifer is equivalent to zones 1 and 2 as used by Joyner and Sutcliffe (1976).

The lower Hawthorn aquifer consists of permeable limestone and dolomite beds in the lower part of the Hawthorn Formation and in the upper part of the Tampa Limestone that is in hydrologic contact with the Hawthorn Formation. The top of the aquifer occurs at depths ranging from about 150 to 300 feet below land surface and is present within the entire Basin.

Because of increasing dissolved solids with depth, the intermediate aquifers are the most highly developed aquifers in the Basin and are used for domestic, home irrigation, and public water supplies. The aquifers supply most of the public water supply for the cities of Sarasota and Venice, as we11 as other public supply systems. Most large irrigation wells that penetrate the Floridan aquifer are also open to the intermediate aquifers.

Wells in the Tamiami-upper Hawthorn aquifer are generally finished as open holes in the rock. Wells less than 4 inches in diameter that partially penetrate the aquifer may produce 25 to $30 \mathrm{gal} / \mathrm{min}$; large diameter wells, 6 inches in diameter or larger, that fully penetrate the aquifers may yield more than $200 \mathrm{gal} / \mathrm{min}$.

The composite potentiometric surface of the intermediate aquifers in May 1977 ranged from about 100 feet above sea level in northeastern Manatee County to less than 10 feet above sea level in coastal areas. In September 1977, the potentiometric surface ranged from about 20 to 100 feet above sea level. Hydrographs of selected wells penetrating the Tamiami-upper Hawthorn aquifer are shown in figure 9. Seasonal water-level fluctuations ranged from about 5 feet in the northeastern and coastal areas to about 20 feet in southern Hillsborough County.

The rate or magnitude of the long-term decline in the potentiometric surface of the Tamiami-upper Hawthorn aquifer cannot be determined accurately from existing data. One well on the west coast, measured periodically from 1953 to 1975 and semiannually since 1976, had declines of about 1 to 4 feet, depending on the season.

\section{$\underline{\text { Floridan aquifer }}$}

The Floridan aquifer, the major source of ground water in the Manasota Basin, is composed of a thick, stratified sequence of limestone and dolomite. The aquifer includes part or all of the Tampa Limestone (lower Miocene), Suwannee Limestone (Oligocene), Ocala Limestone (upper Eocene), and the Avon Park Limestone (middle Eocene).

The limestone and dolomite sequence generally functions as a single hydrogeologic unit; however, three distinct water-bearing zones are known to exist in the sequence. They are the upper zone (Tampa Limestone), the middle zone (the lower part of the Suwannee Limestone), and the lower zone (the Avon Park Limestone below the top $100 \mathrm{feet}$ ). These zones are designated as artesian zones 3, 4, and 5, respectively, by Joyner and Sutcliffe (1976). The highly permeable zones generally occur at or near formation contacts. The zones are separated 


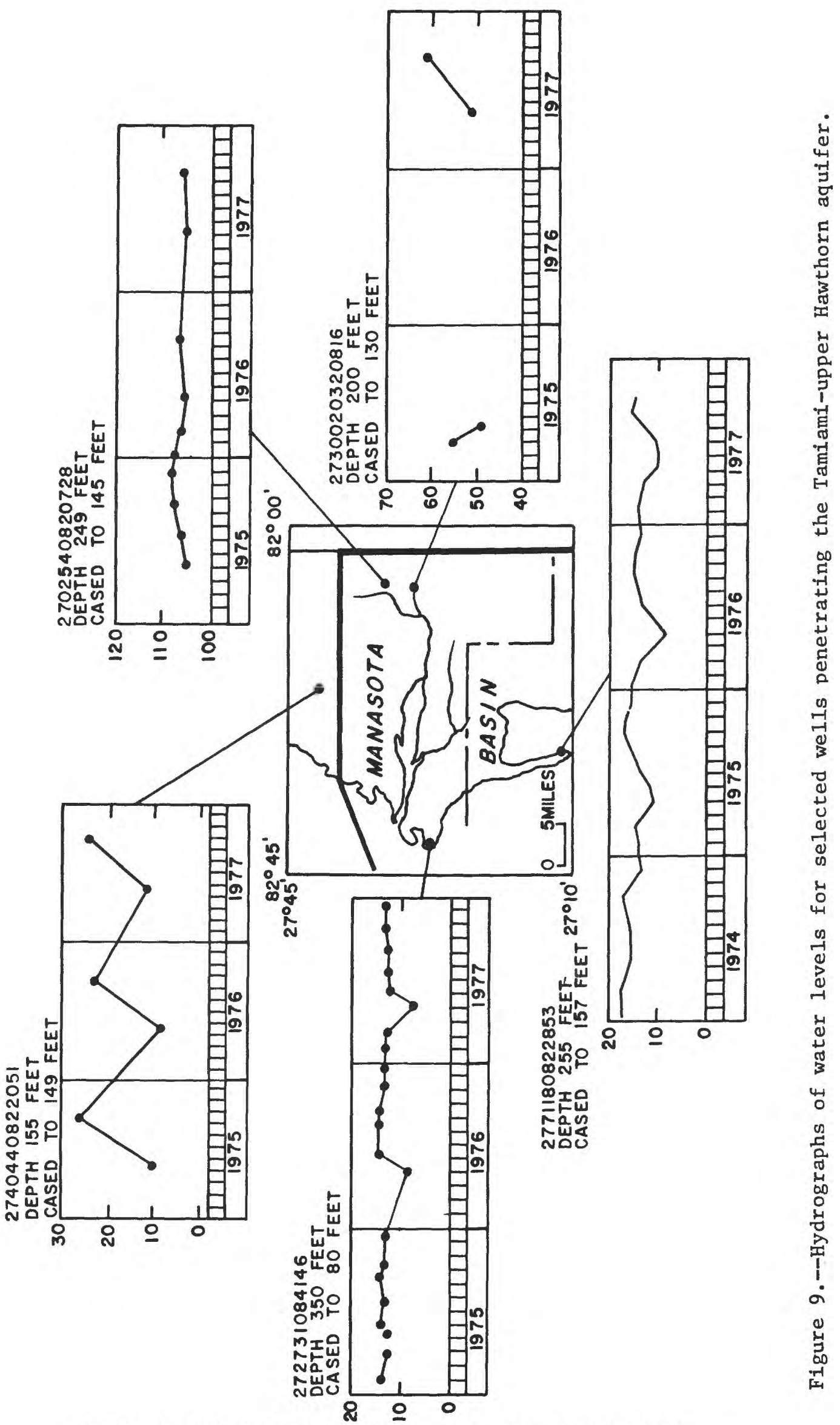


by beds of low permeability that act as semiconfining beds retarding vertical movement of water within the aquifer. The altitude of the top of the Floridan aquifer ranges from about 200 feet below land surface in the northeast to about 400 feet below in the southwest (fig. 10).

The Floridan aquifer is the major source of ground water used primarily for irrigation in the Manasota Basin. Minor amounts of water are used for industrial purposes, air conditioning, and municipal and domestic supplies. The Floridan aquifer (upper and middle zones) was a major source of water for public supply before development of surface-water sources in Manatee County and the surficial and intermediate aquifers in Sarasota County.

The Floridan aquifer yields from about $500 \mathrm{gal} / \mathrm{min}$ to wells less than 6 inches in diameter that partially penetrate the aquifer to about $5,000 \mathrm{gal} / \mathrm{min}$ to wells 12 inches or more in diameter that fully penetrate the aquifer. Most wells are cased only to the first consistent rock and are finished as open hole. In the eastern part of the Basin, the wells range in depth from about 600 to 1,500 feet, depending on quality and quantity of water needed, and depth of casing generally ranges from about 200 to 500 feet below land surface. In the western part and coastal areas, wells are generally less than 800 feet deep with casing depths ranging from about 50 to 200 feet below land surface.

Figure 11 shows hydrographs of water levels for selected wells penetrating one or more zones of the Floridan aquifer. The hydrographs show a general downward trend in water levels and an increase in seasonal fluctuation of water levels. The downward trend indicates that ground-water discharge exceeds recharge, possibly due to below normal rainfall and increased pumping. The wide range of seasonal fluctuations results primarily from pumping for irrigation in the spring.

The configuration of the potentiometric surface of the Floridan aquifer is shown in figures 12, 13, and 14. In May 1975, the potentiometric surface of the Floridan aquifer ranged from about 10 feet below sea level in the north-central part of the basin to about 40 feet above sea level in the southeastern part (fig. 12). The depression in the north-central part probably resulted from groundwater withdrawals by irrigation and public supply wells. At the coast, the potentiometric surface is relatively high, generally about 10 feet above sea level. The potentiometric surface in May 1977 (fig. 13) is similar to May 1975 (fig. 12) and may indicate that the aquifer is approaching equilibrium at present withdrawal rates. The decline in the potentiometric surface of the Floridan aquifer from May 1969 to May 1975 (fig. 12) ranged from 0 to 5 feet in the south and west to more than 40 feet in the northeast.

The potentiometric surface in September 1977 (fig. 14) ranged from about 20 feet above sea level in the north-central part to about 40 feet above sea level in the southeast. The decline in the potentiometric surface in Manatee County from September 1954 to September 1975 ranged from less than 5 feet near the coast to about 20 feet in the northeastern part of the county. Seasonal fluctuation in the potentiometric surface ranged from less than 5 feet near the coast to about 30 feet in the northeast.

Projected declines in the potentiometric surface of the Floridan aquifer that will result from changes in land use and in ground-water development are shown in figures 15 and 16 (modified from Wilson, 1977). The projected potentiometric surfaces were determined using projected water use for 1976-2000 and a finite-difference, two-dimensional model. 


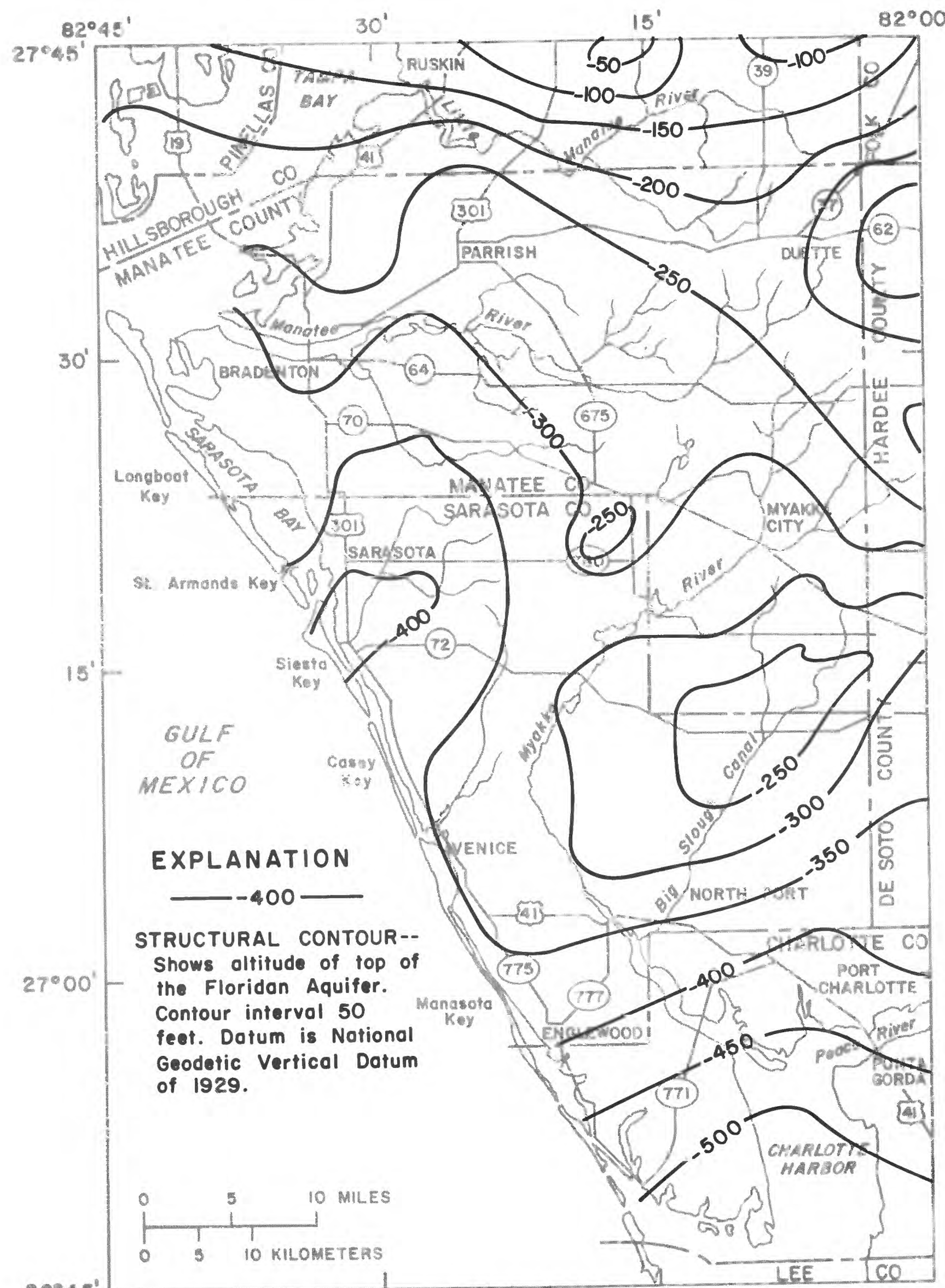

Figure 10.--Altitude of the top of the Floridan aquifer (from Buono and Rutledge, 1978). 


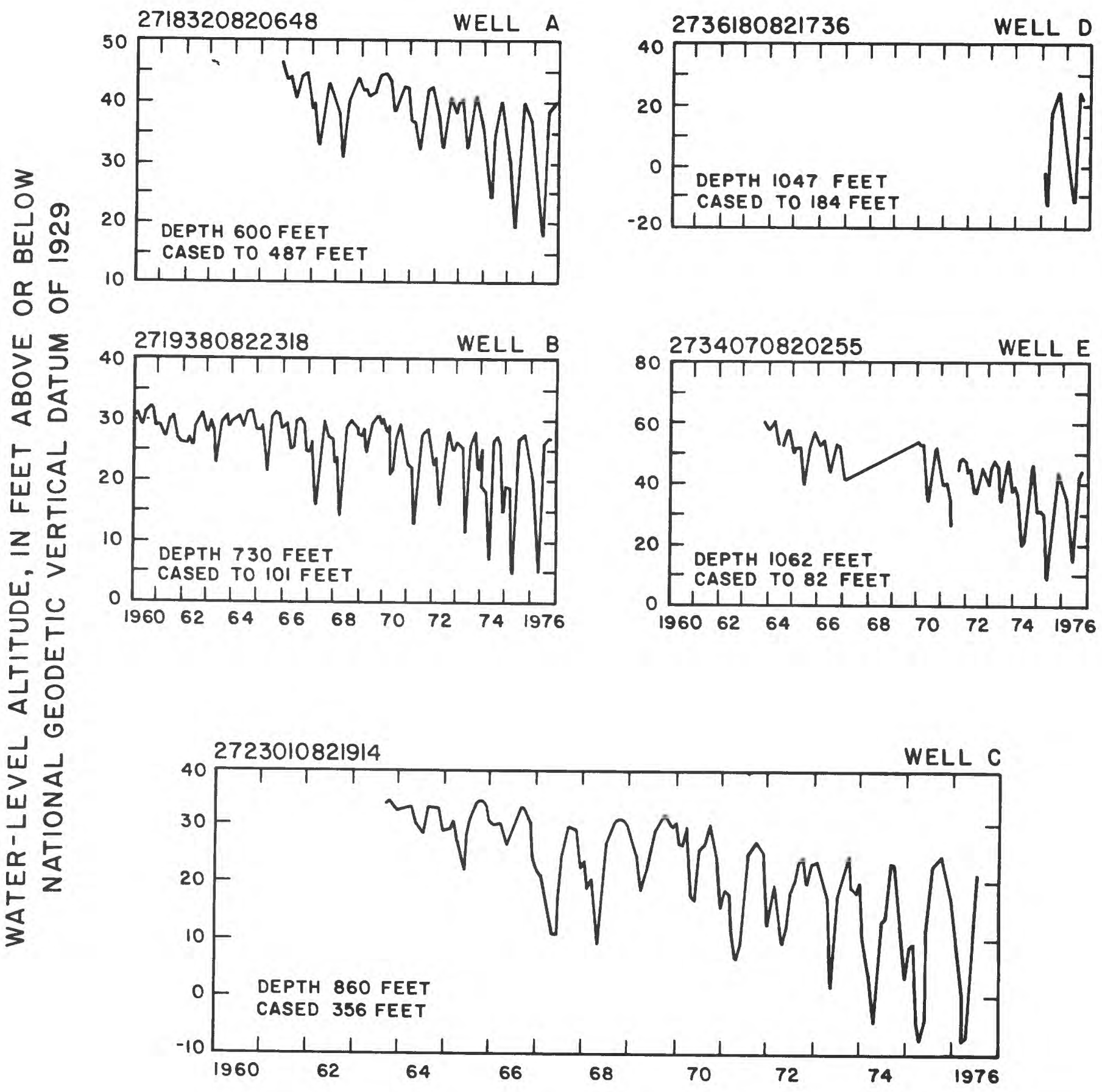

Figure 11.--Hydrographs of water levels for selected wells penetrating the Floridan aquifer. (Locations of wells are shown in figure 13). 


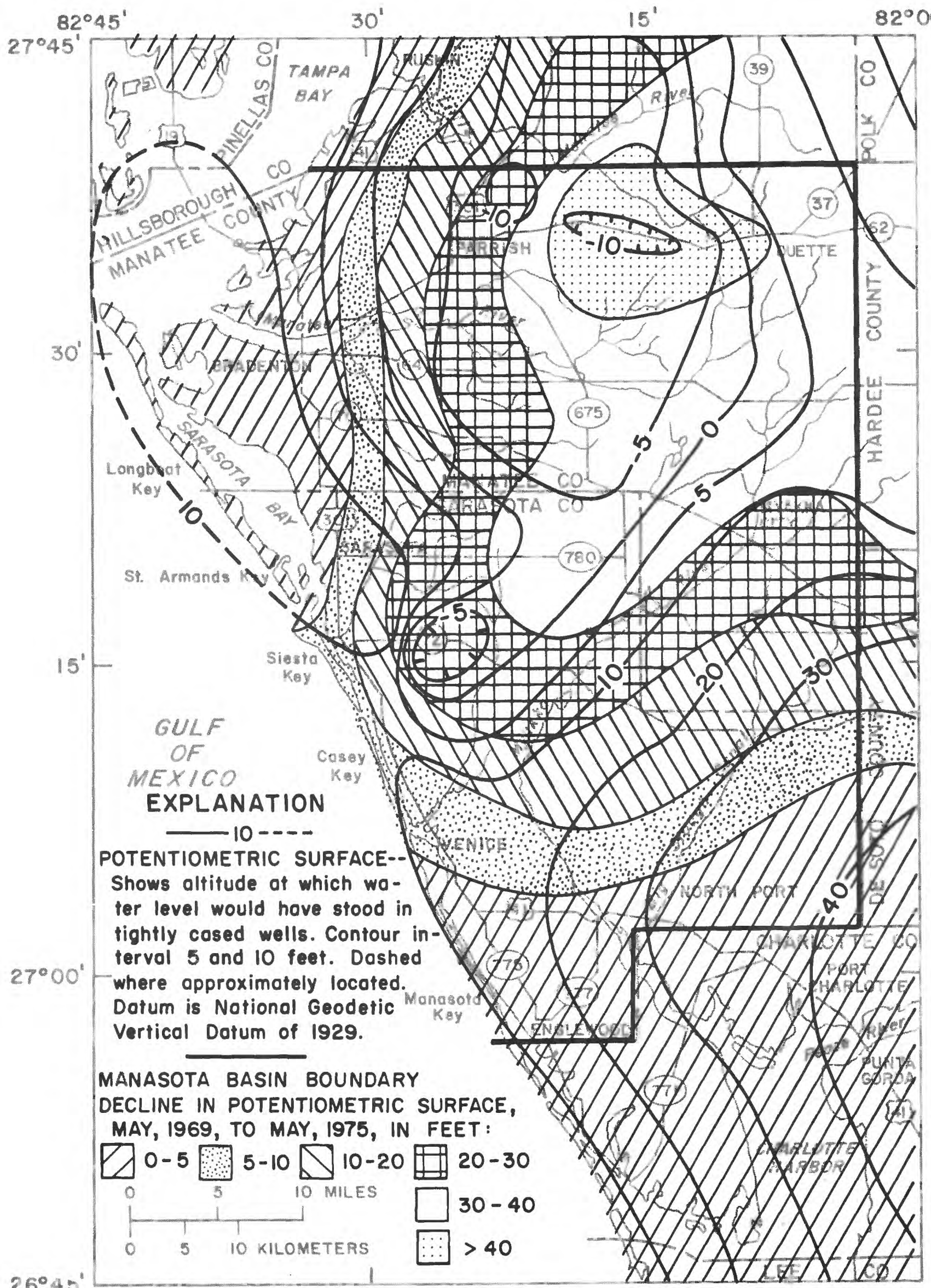

Figure 12.--Potentiometric surface of the Floridan aquifer, May 1975, and change in potentiometric surface, May 1969 to May 1975 (from Mills and Laughlin, 1976). 


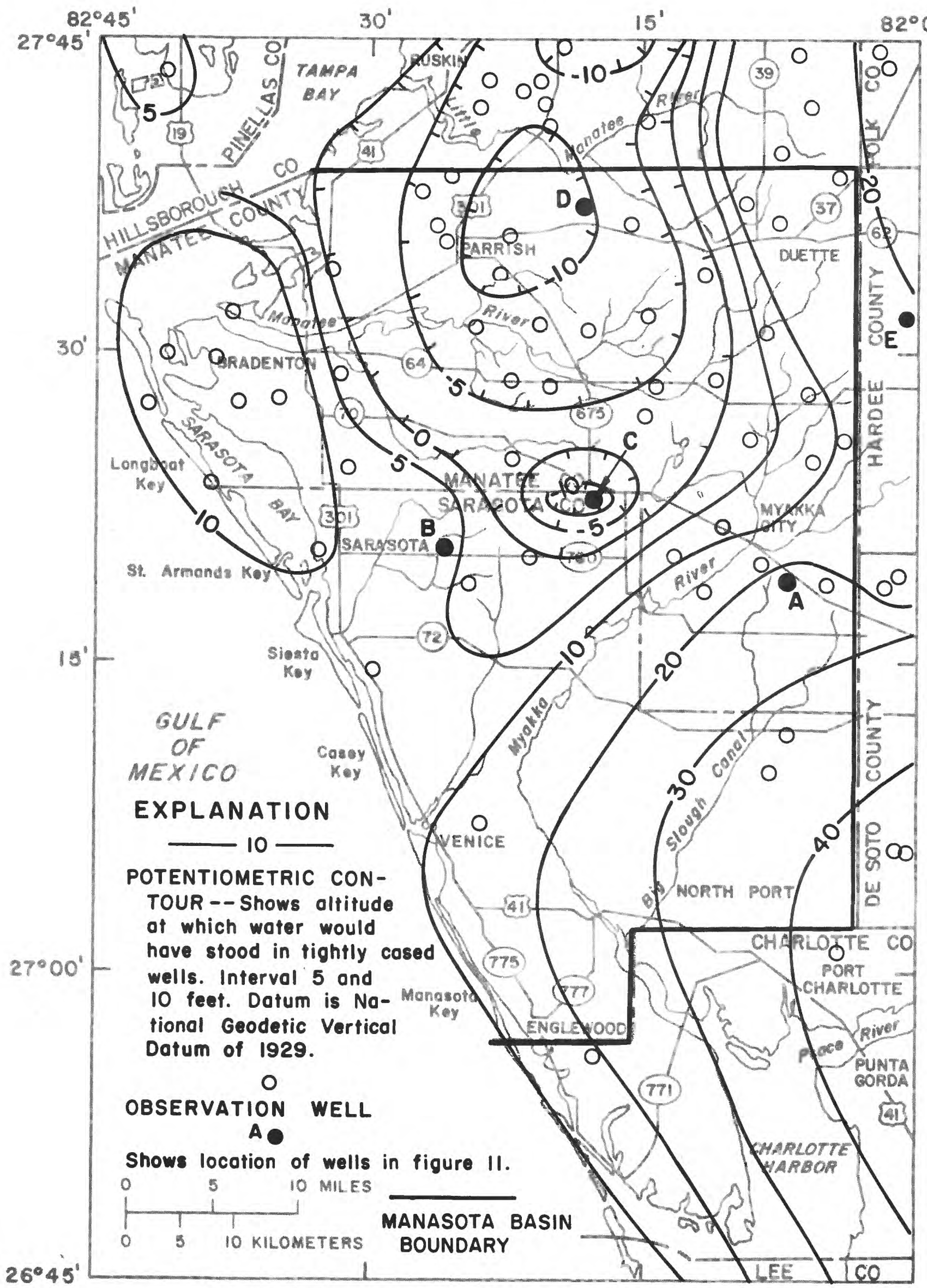

Figure 13.--Potentiometric surface of the Floridan aquifer, May 1977 (from Ryder and others, 1977c). 


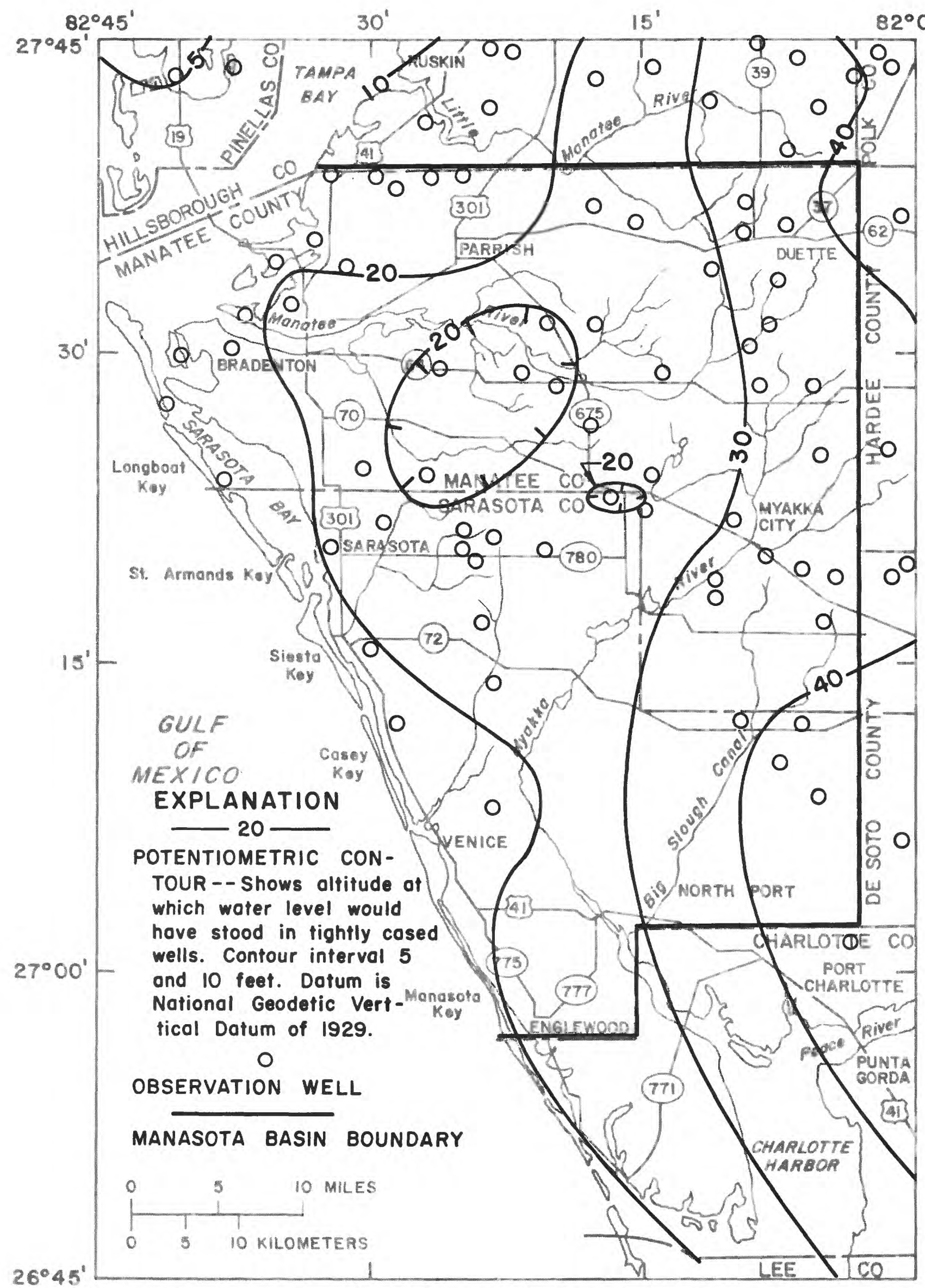

Figure 14.--Potentiometric surface of the Floridan aquifer, September 1977 (from Ryder and others, 1978). 


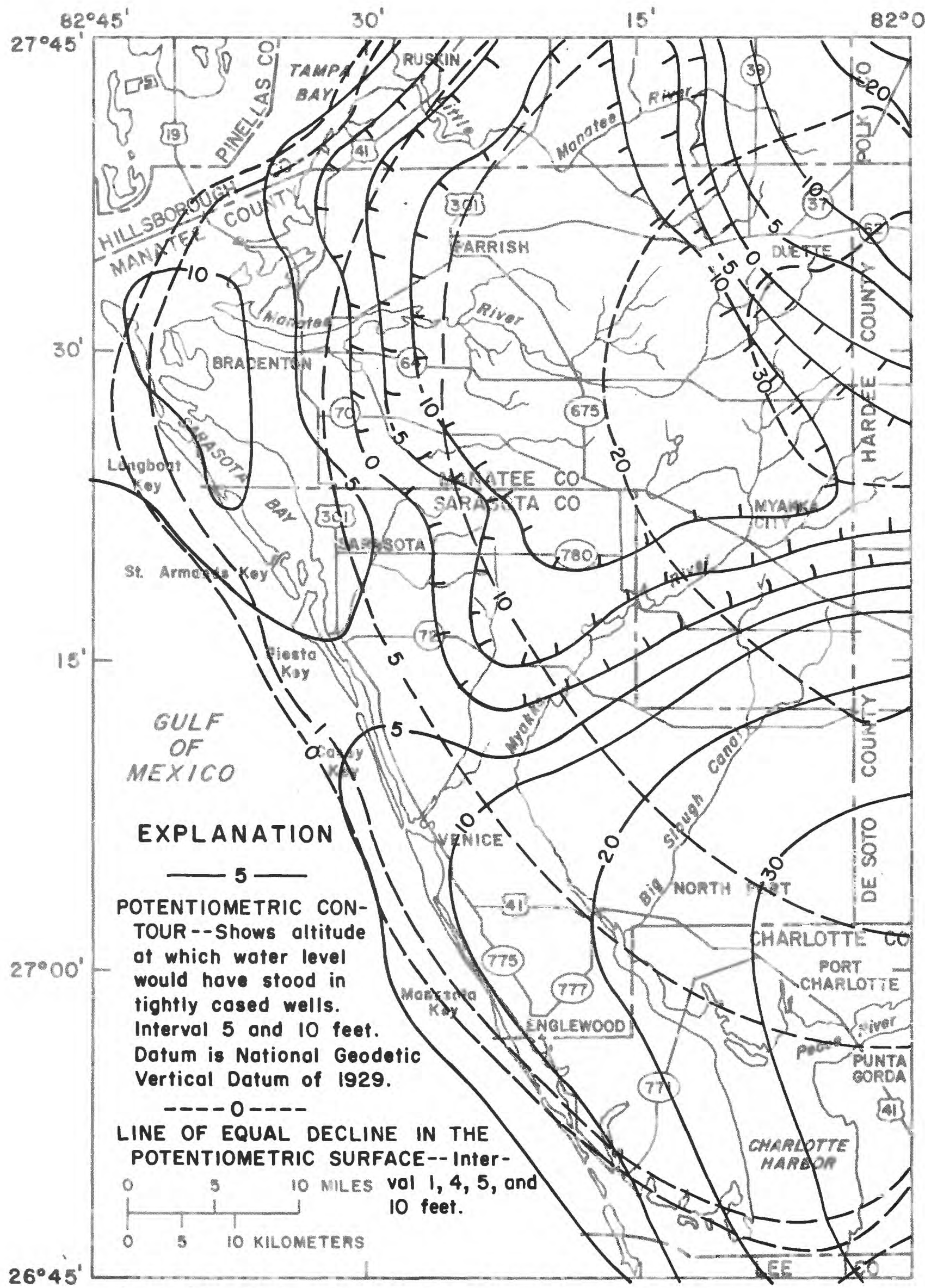

Figure 15.--Projected potentiometric surface of the Floridan aquifer, May 2000, and decline in the potentiometric surface, May 1976 to May 2000 (modified from Wilson, 1977). 


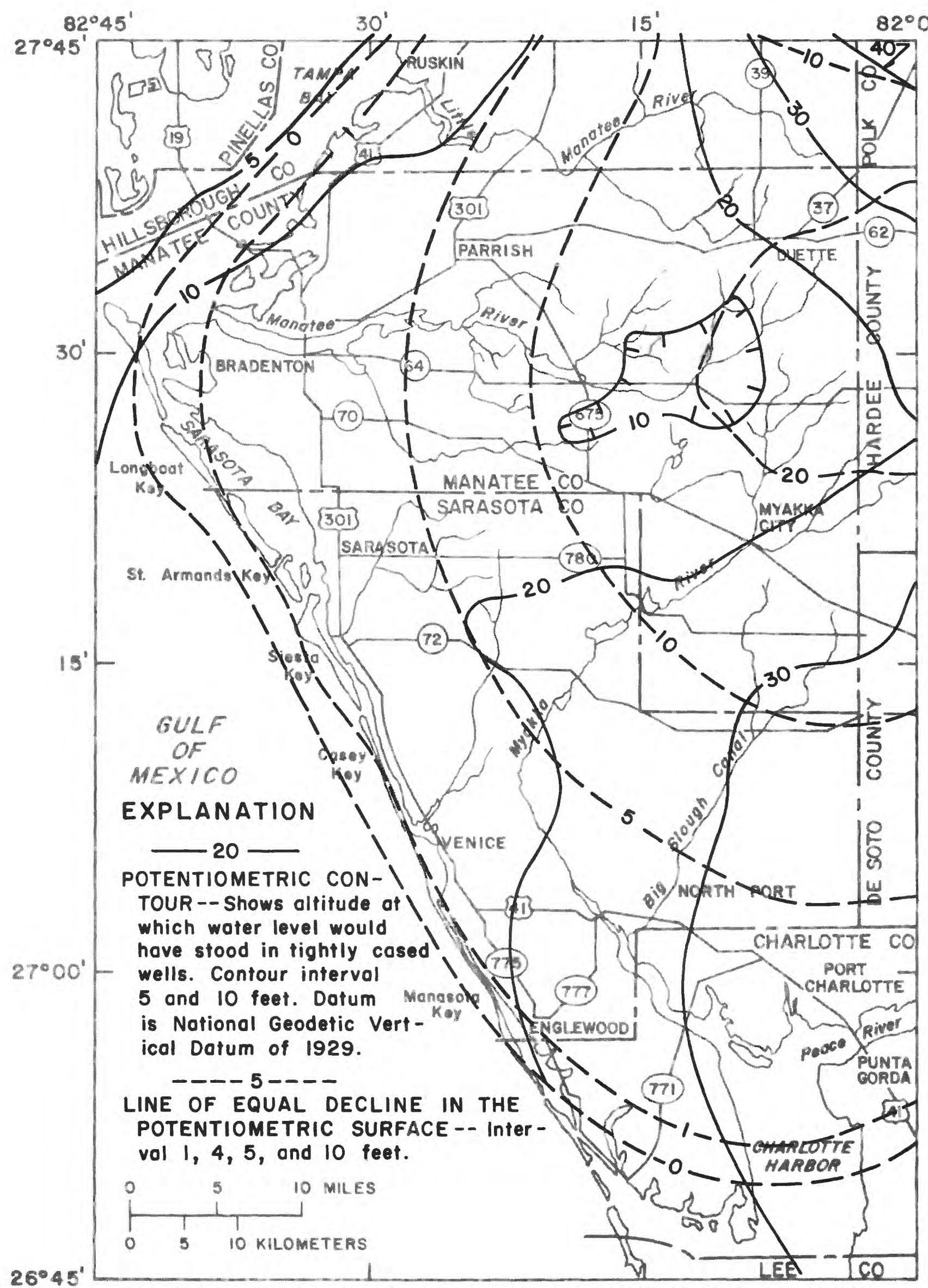

Figure 16.--Projected potentiometric surface of the Floridan aquifer, October 2000, and decline in the potentiometric surface, November 1976 to October 2000 (modified from Wilson, 1977). 
The projected potentiometric surface for May 2000 (seasonal low) ranges from about 10 feet below sea level in the north-central part of the Basin to about 30 feet above sea level in the southeastern part. Projected declines from May 1976 to May 2000 range from less than 5 feet along the coast to about 30 feet in the northeast (fig. 15). In October 2000 (seasonal high), the projected altitude of the potentiometric surface ranges from about 10 feet above sea level along the northwestern coast to about 30 feet above sea level in the southeast. The projected decline in the potentiometric surface from November 1976 to October 2000 ranges from zero along the coast to about 20 feet in the northeast (fig. 16).

\section{Sub-Floridan confining unit}

The Lake City Limestone is the lower confining unit of the Floridan aquifer and retards upward movement of saline water. In the northeastern part of the Basin, the Lake City Limestone, from depths of about 1,700 to 2,000 feet below land surface, consists of limestone and dolomite that contain evaporites within much of the intergranular pore space and in distinct layers. The unit contained highly mineralized water and was described as being very impermeable (William F. Guyton and Associates, 1976d).

\section{Chemical Quality of Water}

The quality of ground water is affected by composition and solubility of the soil and rock through which the water passes and the residence time of the water. Water in each aquifer or water-bearing zone may have distinctive waterquality characteristics. Thus, the quality of water pumped from a well depends on the aquifer or zone to which the well is open. Wells that penetrate deep aquifers are commonly constructed with tens to many hundreds of feet of openhole (no casing) and are open to one or more aquifers or water-bearing zones.

Ground water in the Manasota Basin contains dissolved mineral matter (dissolved solids) in varying amounts that affect the quality of water. Water having a low dissolved solids concentration is generally more suitable than water having high dissolved solids concentration. The source and significance of various constituents and properties of water are discussed in detail by Hem (1970). Those properties that have a practical bearing on water use are summarized in "Water Resources Data for Florida--Water Year 1976" (U.S. Geological Survey, 1977).

The principal constituents that determine the potability and use of ground water in the study area are dissolved solids, sulfate, and chloride. Recommended limits for public water supplies for these constituents are 500, 250, and 250 milligrams per liter (mg/L), respectively (U.S. Environmental Protection Agency, 1979). 
The dissolved solids in water from the surficial aquifer varies. Water is generally of potable quality except near the coast and tidally affected streams and in the peninsula south and west of the Myakka River estuary (Joyner and Sutcliffe, 1976). In these areas, saltwater intrusion has taken place.

In the northeast, concentrations of dissolved solids, chloride, and sulfate are generally less than 200,50 , and $10 \mathrm{mg} / \mathrm{L}$, respectively (fig. 17). In this area, the surficial aquifer is primarily well-sorted sand, and water from the aquifer has a low dissolved solids concentration.

Near the coast and tidally affected streams, water in the surficial aquifer has higher dissolved solids concentration. Concentrations of dissolved solids and chlorides are generally more than 200 and $50 \mathrm{mg} / \mathrm{L}$, respectively. Concentrations of sulfate vary considerably, but they are usually less than $20 \mathrm{mg} / \mathrm{L}$.

Intermediate aquifers and confining beds

The water in the intermediate aquifers within the intermediate confining beds overlying the Floridan aquifer contains low dissolved solids, except near the coast and inland areas where saltwater intrusion has taken place or seawater has not been completely flushed from the aquifers.

The quality of water from wells that penetrate the permeable beds of the Tamiami Formation (zone 1) varies greatly. Dissolved solids concentrations range from about 300 to $5,000 \mathrm{mg} / \mathrm{L}$, generally being highest near the coast and in the southern part of the Basin. Chloride is generally less than $250 \mathrm{mg} / \mathrm{L}$, except in the coastal areas near Venice and Englewood and the peninsula area west of the Myakka River where concentrations are generally more than 1,000 $\mathrm{mg} / \mathrm{L}$. Sulfate is generally less than $250 \mathrm{mg} / \mathrm{L}$, except in coastal areas near Venice and north of Englewood where concentrations range from about 20 to 600 $\mathrm{mg} / \mathrm{L}$.

Water from wells that penetrate the upper part of the Hawthorn Formation (zone 2) is generally low in dissolved solids except in coastal and southeastern areas. Dissolved solids range from about 250 to $500 \mathrm{mg} / \mathrm{L}$ in the northeast and about 500 to $3,000 \mathrm{mg} / \mathrm{L}$ along the coast (fig. 18). Concentrations of more than $500 \mathrm{mg} / \mathrm{L}$ extend about 15 miles inland along the Myakka River to Upper Myakka Lake and also southeast of Myakka City. Chloride concentrations range from about 10 to $2,000 \mathrm{mg} / \mathrm{L}$ with concentrations greater than $250 \mathrm{mg} / \mathrm{L}$ being limited to the coastal and southern parts of the Basin (fig. 19). Sulfate concentrations range from about 10 to $600 \mathrm{mg} / \mathrm{L}$, generally increasing from the northern part of the Basin towards the south and west (fig. 20). Concentrations greater than $250 \mathrm{mg} / \mathrm{L}$ are limited to coastal areas and to a small area southeast of Myakka City. Fluoride concentrations in water from wells penetrating zone 2 range from 0.1 to 6.0 $\mathrm{mg} / \mathrm{L}$ (Joyner and Sutcliffe, 1976). 


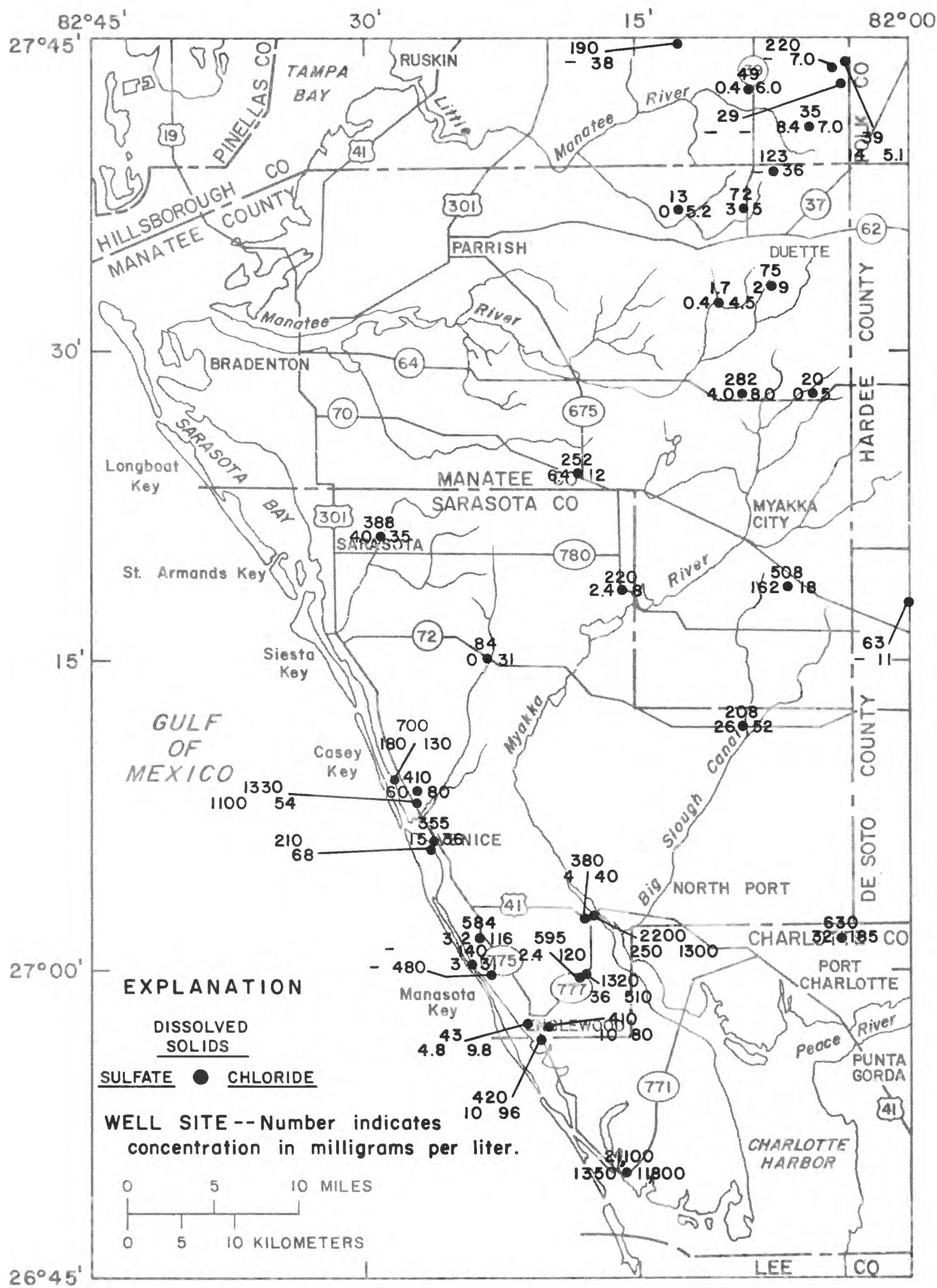

Figure 17.--Chemical quality of water from wells penetrating the surficial aquifer. 


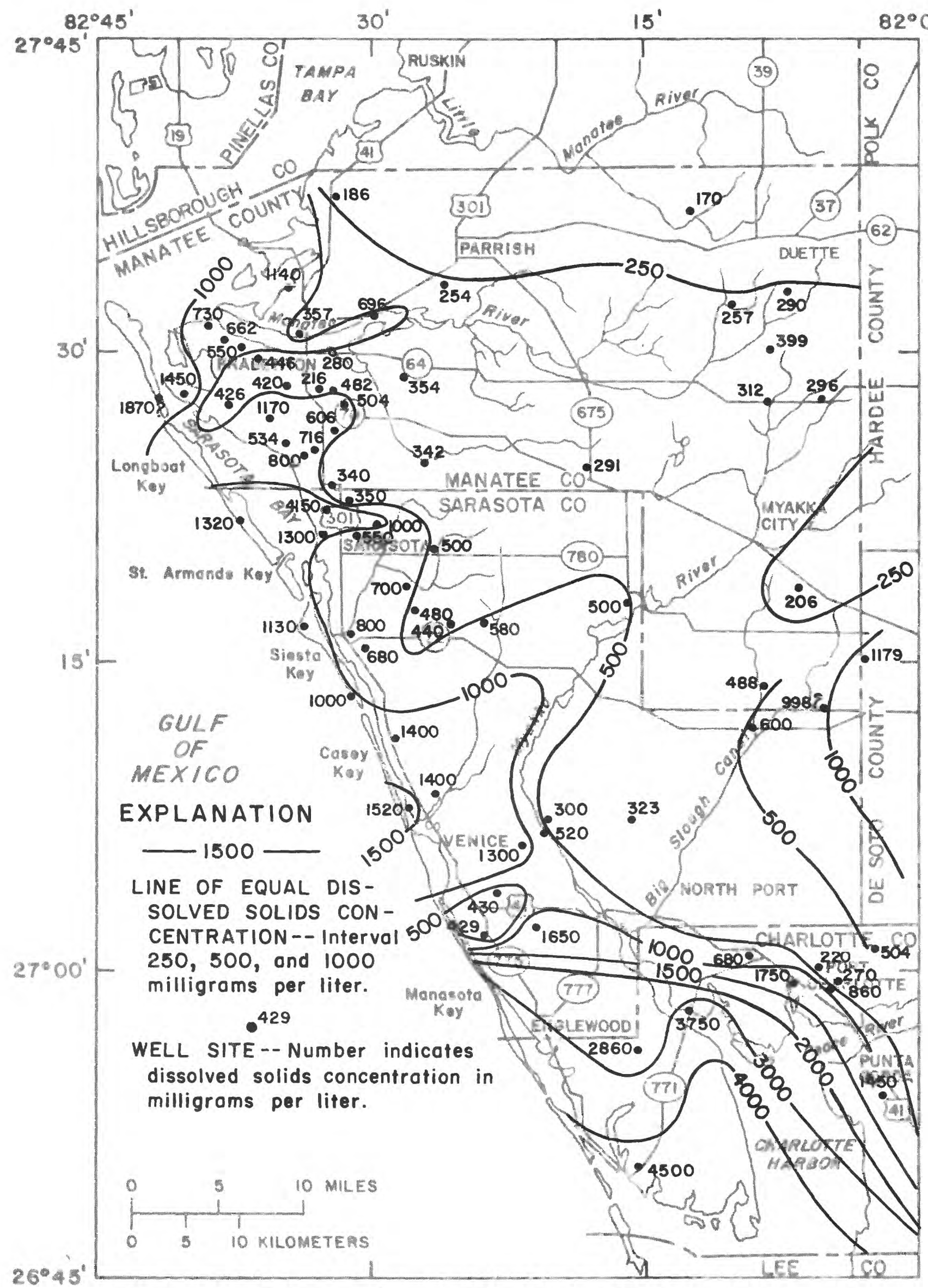

Figure 18.--Concentrations of dissolved solids in water from wells penetrating the Tamiami-upper Hawthorn aquifer. 


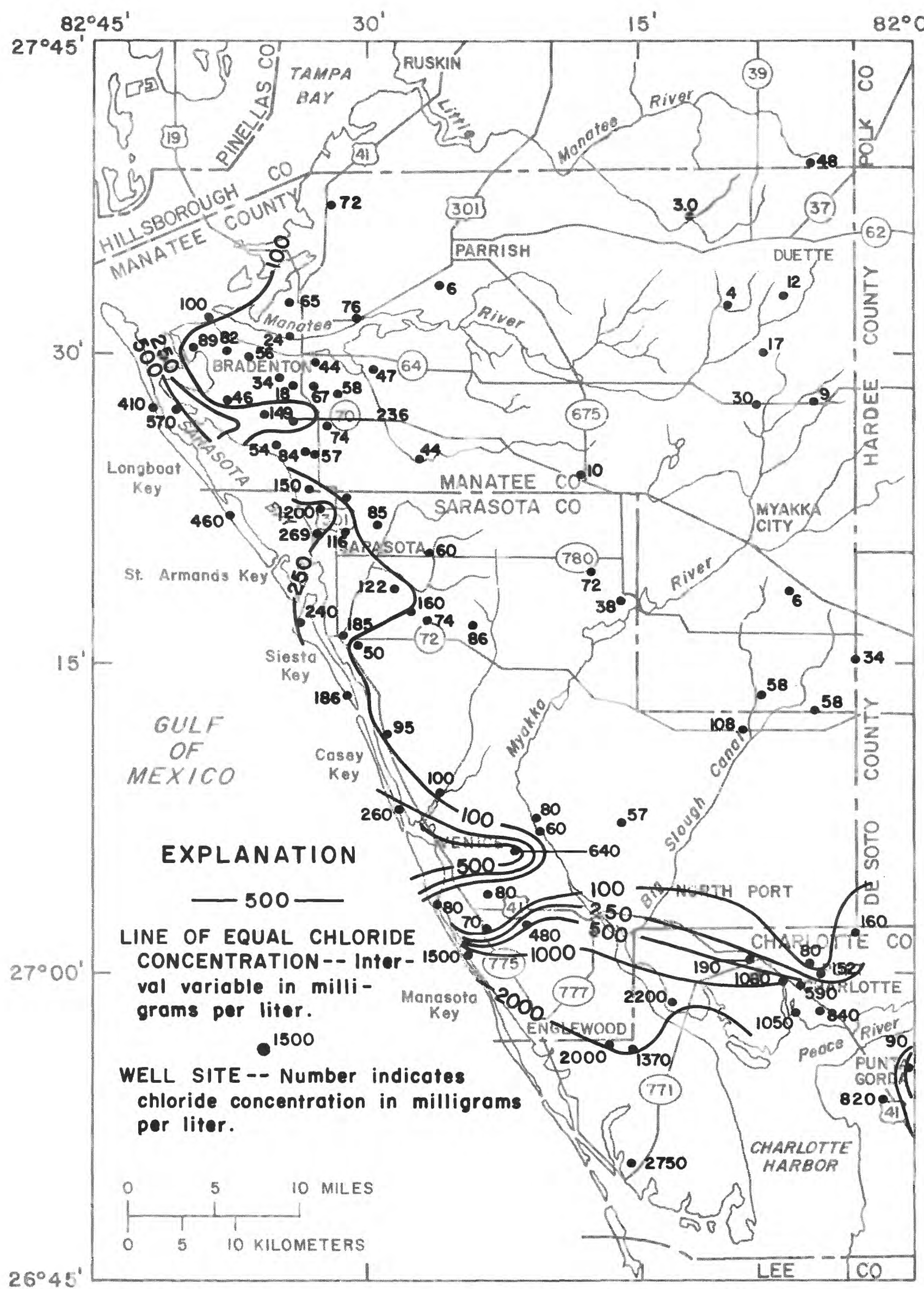

Figure 19.--Concentrations of chloride in water from wells penetrating the Tamiami-upper Hawthorn aquifer. 


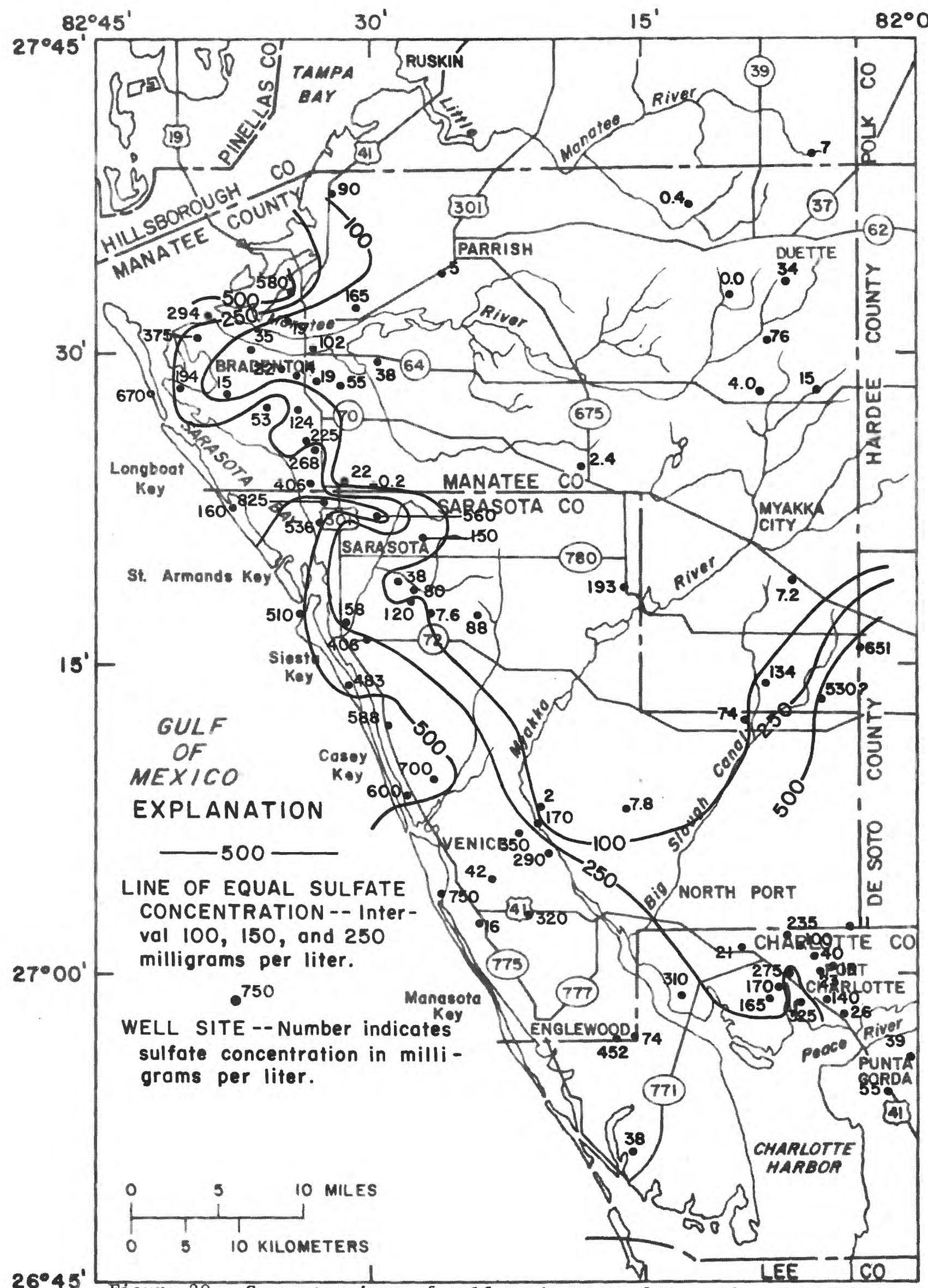

$26^{\circ} 45^{\prime}$ Figure 20.--Concentrations of sulfate in water from wells penetrating the Tamiami-upper Hawthorn aquifer. 
Water in the Floridan aquifer is generally more mineralized than water from the surficial aquifer and intermediate aquifers. Water from wells open to the upper zone (Tampa Limestone) is generally less mineralized than water from wells open to the middle zone (Suwannee and Ocala Limestones). Water in the lower zone (Avon Park Limestone) has the highest mineralization.

Dissolved solids in water from the Floridan aquifer generally increase with depth and laterally from the northeast towards the west and south. Dissolved solids in water from the upper zone exceed $500 \mathrm{mg} / \mathrm{L}$ in the western and southern parts of the Basin (fig. 21). In the northeast, the upper zone is not currently used as a water supply, but the dissolved solids are probably less than $350 \mathrm{mg} / \mathrm{L}$.

Dissolved solids range from about 225 to $2,500 \mathrm{mg} / \mathrm{L}$ in water from wells penetrating the middle zone (fig. 22). In the northeastern part of the Basin, dissolved solids are less than $500 \mathrm{mg} / \mathrm{L}$. In the western and southern parts, dissolved solids range from about 600 to $2,500 \mathrm{mg} / \mathrm{L}$.

Concentrations of dissolved solids range from about 300 to $4,400 \mathrm{mg} / \mathrm{L}$ in water from wells penetrating the lower zone (fig. 23). In the northeast, dissolved solids are generally less than $400 \mathrm{mg} / \mathrm{L}$. In the western and southern parts, dissolved solids exceed $1,000 \mathrm{mg} / \mathrm{L}$. Relatively high concentrations of dissolved solids, exceeding $1,000 \mathrm{mg} / \mathrm{L}$, occur northeast of Parrish and northwest of Myakka City, probably a result of lateral migration of saline water because of pumping or upconing of connate water from deeper parts of the aquifer.

Concentrations of sulfate in water from the Floridan aquifer range from less than 5 to about $1,500 \mathrm{mg} / \mathrm{L}$, generally increasing vertically with depth and laterally from the northeast towards the west and south. In the upper zone, relatively high concentrations of sulfate $(250 \mathrm{mg} / \mathrm{L})$ are limited to the coastal areas (fig. 24).

Relatively high concentrations of sulfate in water from wells penetrating the middle zone extend inland east of Parrish and north of Myakka City (fig. 25). In water from wells penetrating the upper part of the lower zone, concentrations of sulfate generally exceed $250 \mathrm{mg} / \mathrm{L}$ except in the northeast (fig. 26).

Chloride concentrations in all three zones are less than $250 \mathrm{mg} / \mathrm{L}$, except near the coast and the southern parts of the Basin where saltwater intrusion or flushing of residual seawater has been incomplete (figs. 27, 28, and 29). In the northeast, concentrations are generally less than $50 \mathrm{mg} / \mathrm{L}$, and there is little change with depth. In the coastal and southern parts, concentrations generally exceed $250 \mathrm{mg} / \mathrm{L}$, tending to increase seaward and with depth.

Fluoride concentrations in water from the Floridan aquifer vary areally and vertically, ranging from 0.2 to about $3.2 \mathrm{mg} / \mathrm{L}$. Concentrations of fluoride in water from wells penetrating middle and lower zones generally increase from the north and northeast towards the south and west (figs. 30 and 31). 


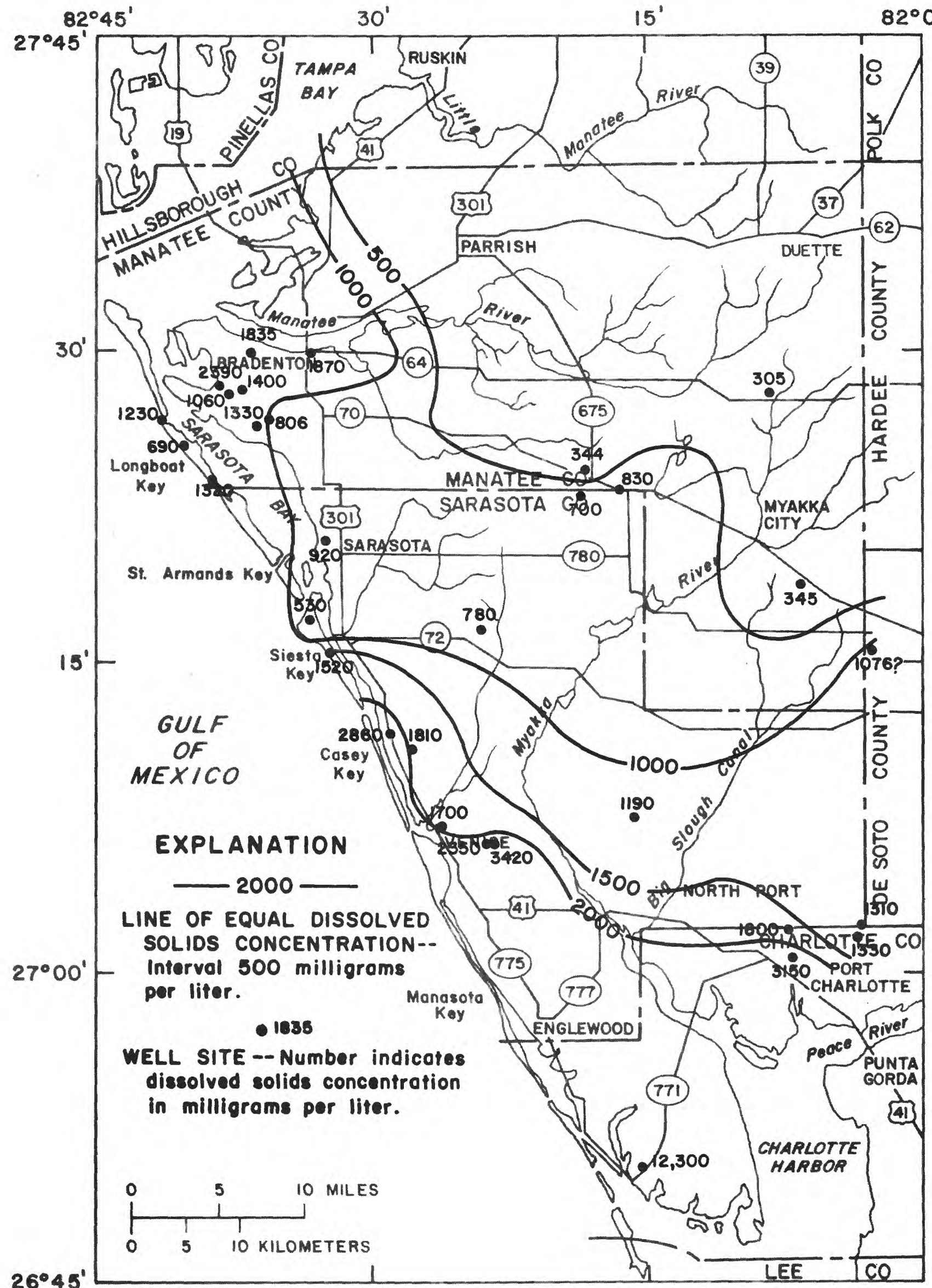

Figure 21.--Concentrations of dissolved solids in water from wells penetrating the upper zone of the Floridan aquifer. 


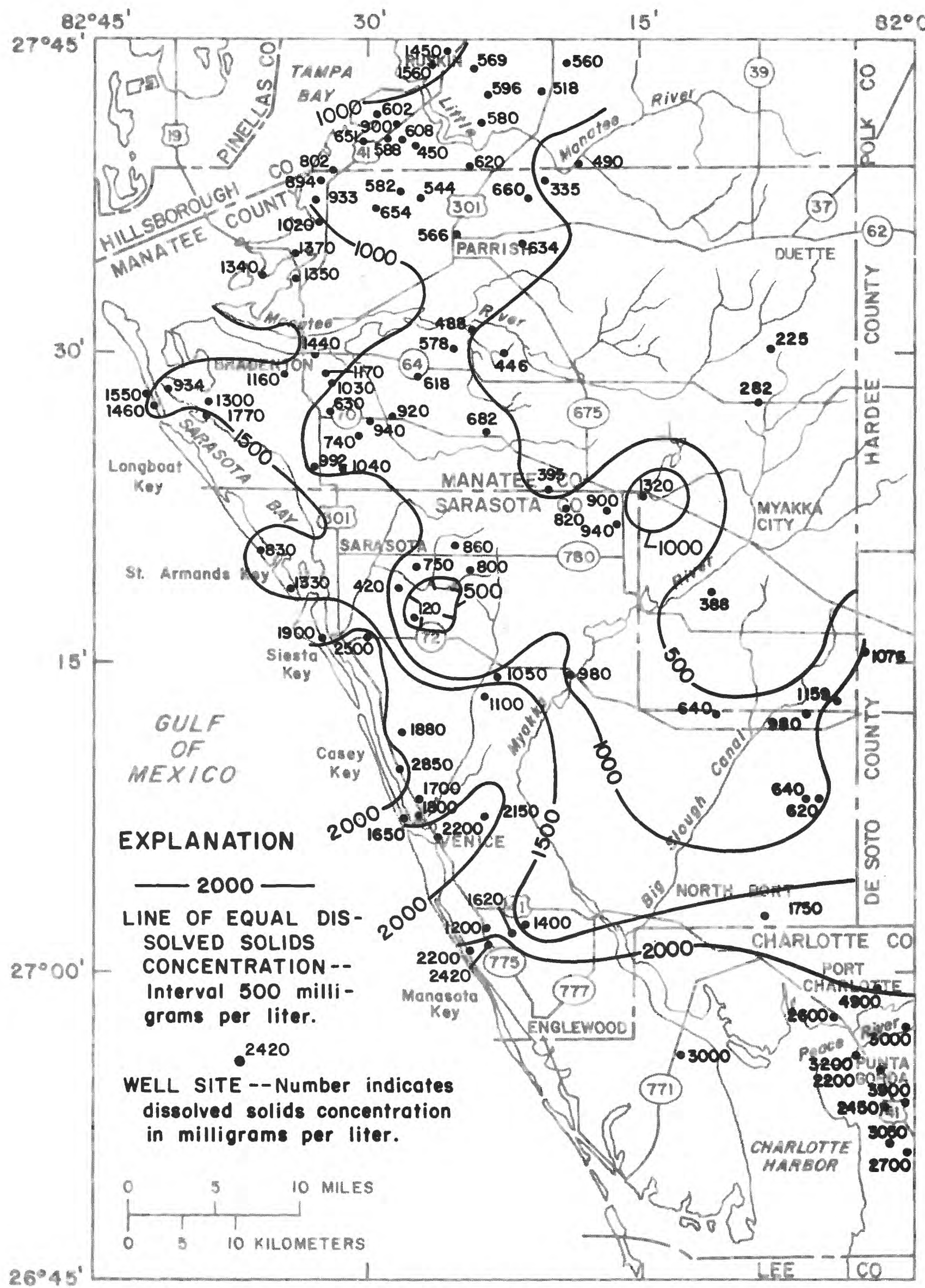

Figure 22.--Concentrations of dissolved solids in water from wells penetrating the middle zone of the Floridan aquifer. 


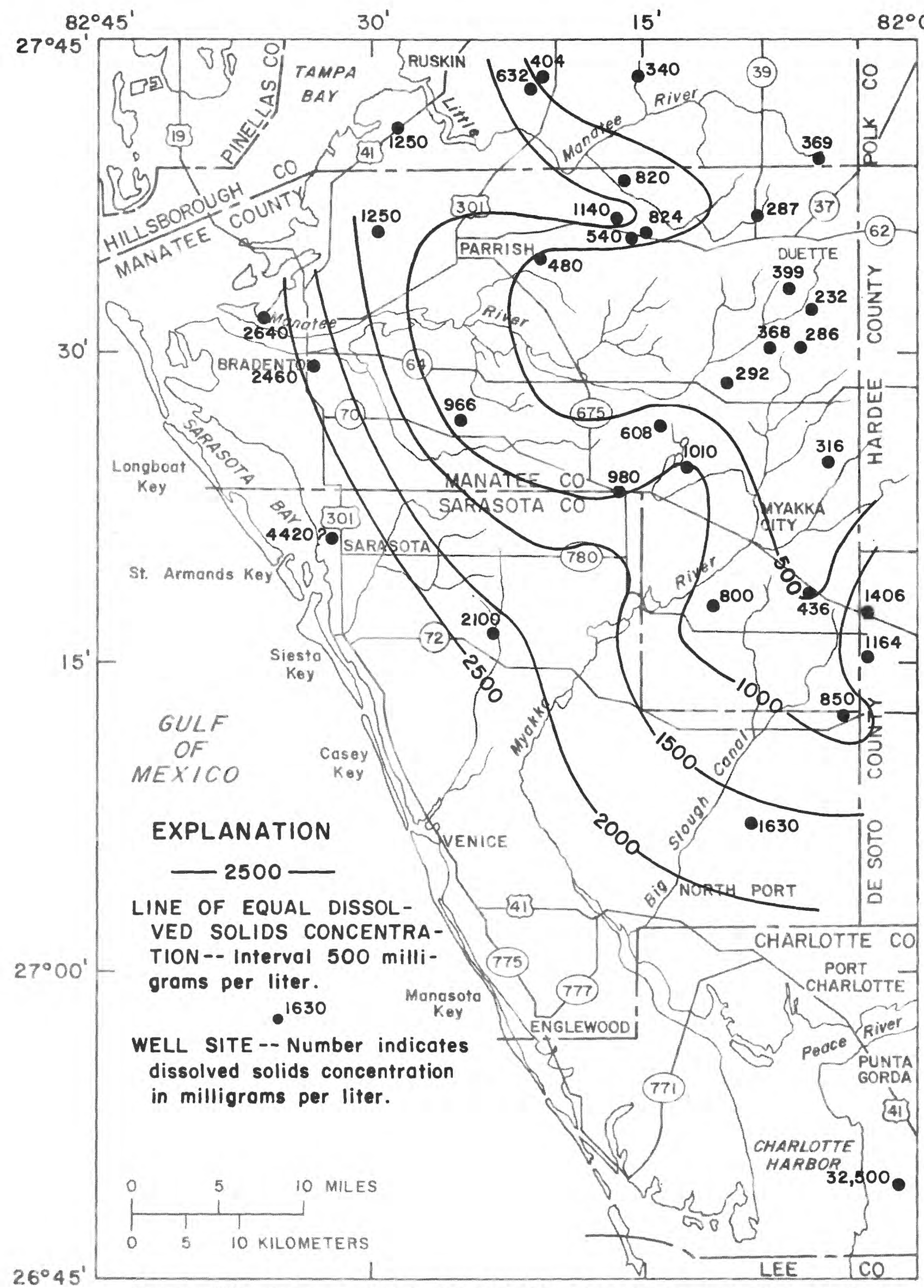

Figure 23.--Concentrations of dissolved solids in water from wells penetrating the lower zone of the Floridan aquifer. 


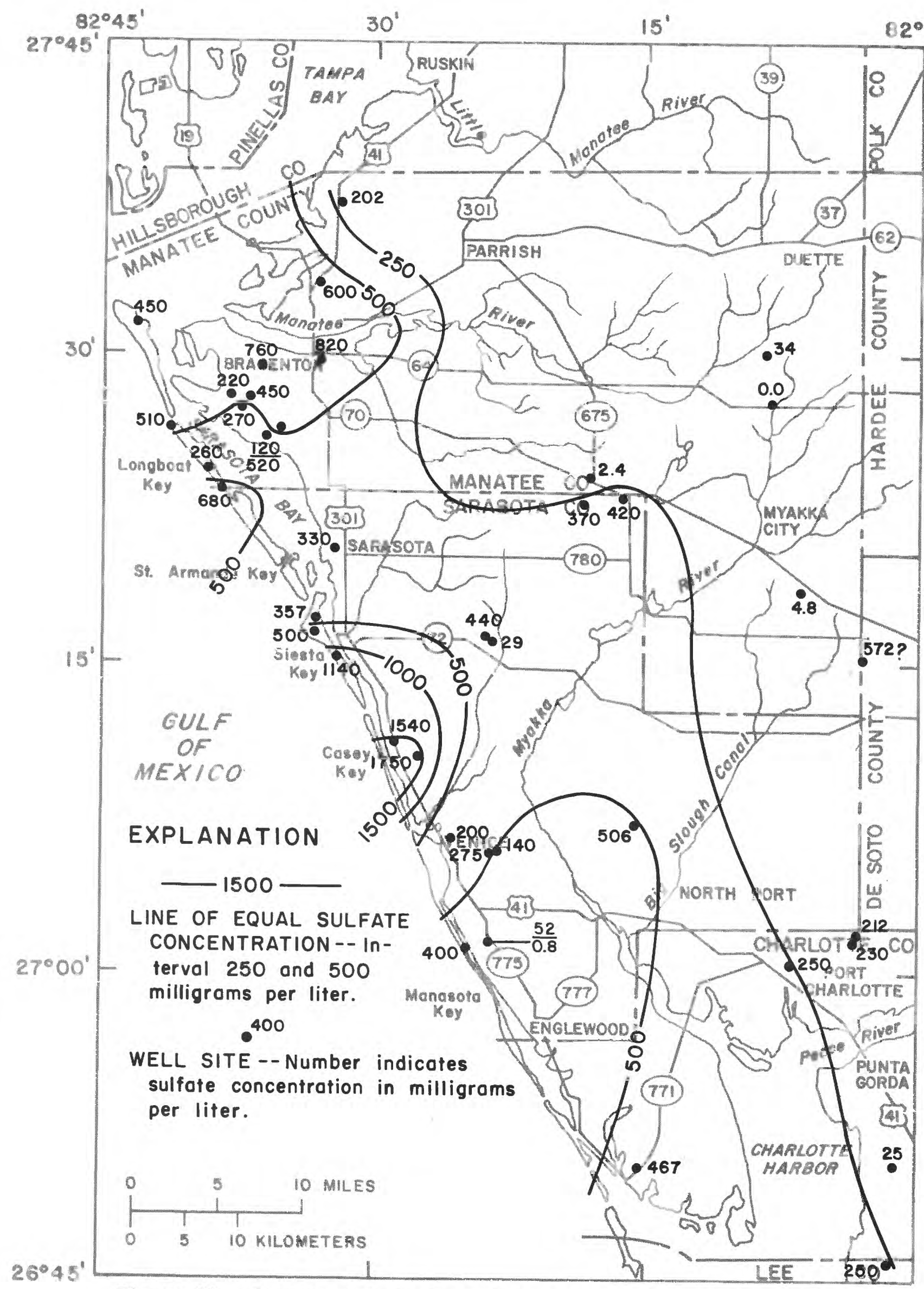

Figure 24.--Concentrations of sulfate in water from wells penetrating the upper zone of the Floridan aquifer. 


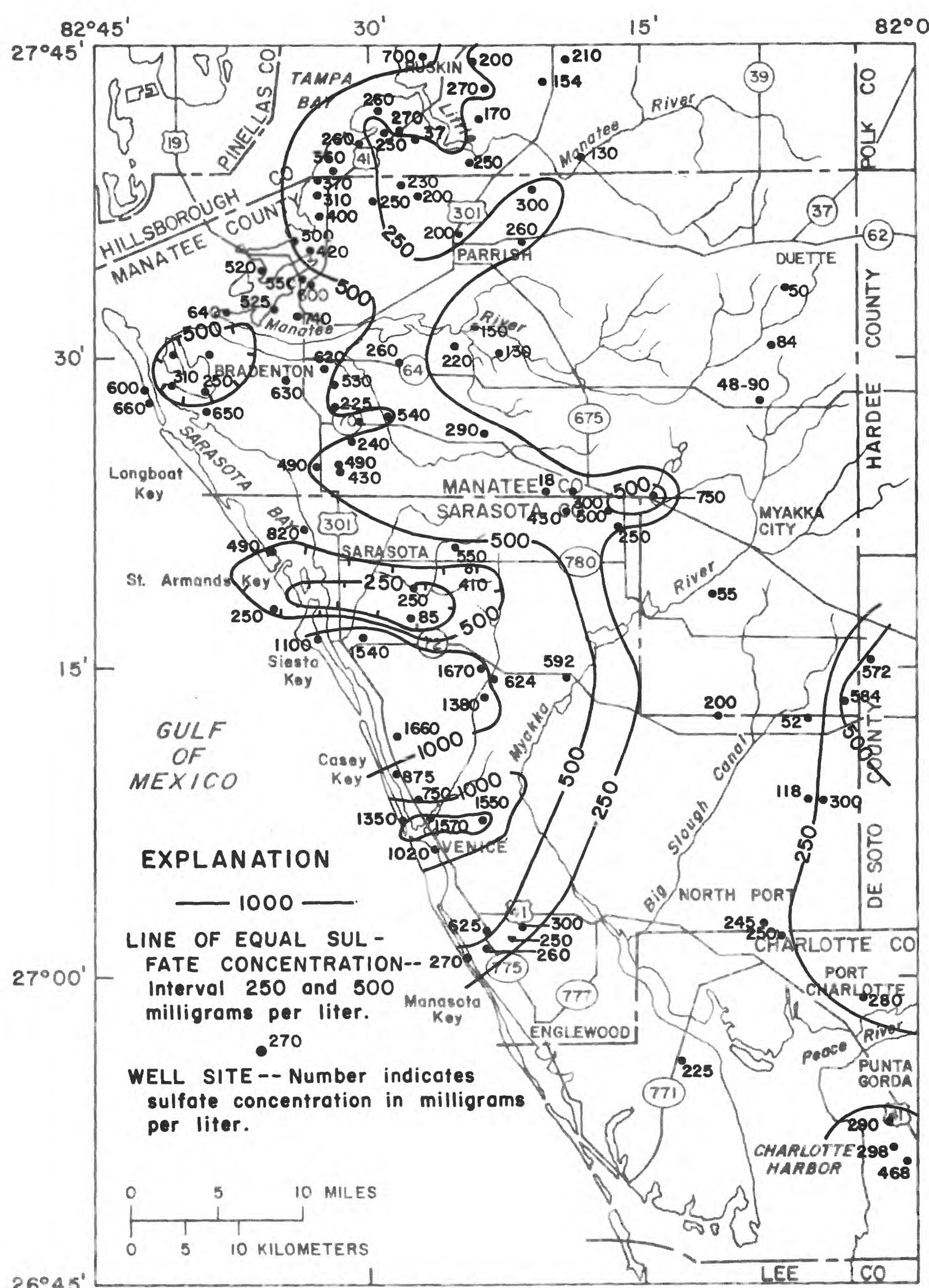

Figure 25.--Concentrations of sulfate in water from wells penetrating the middle zone of the Floridan aquifer. 


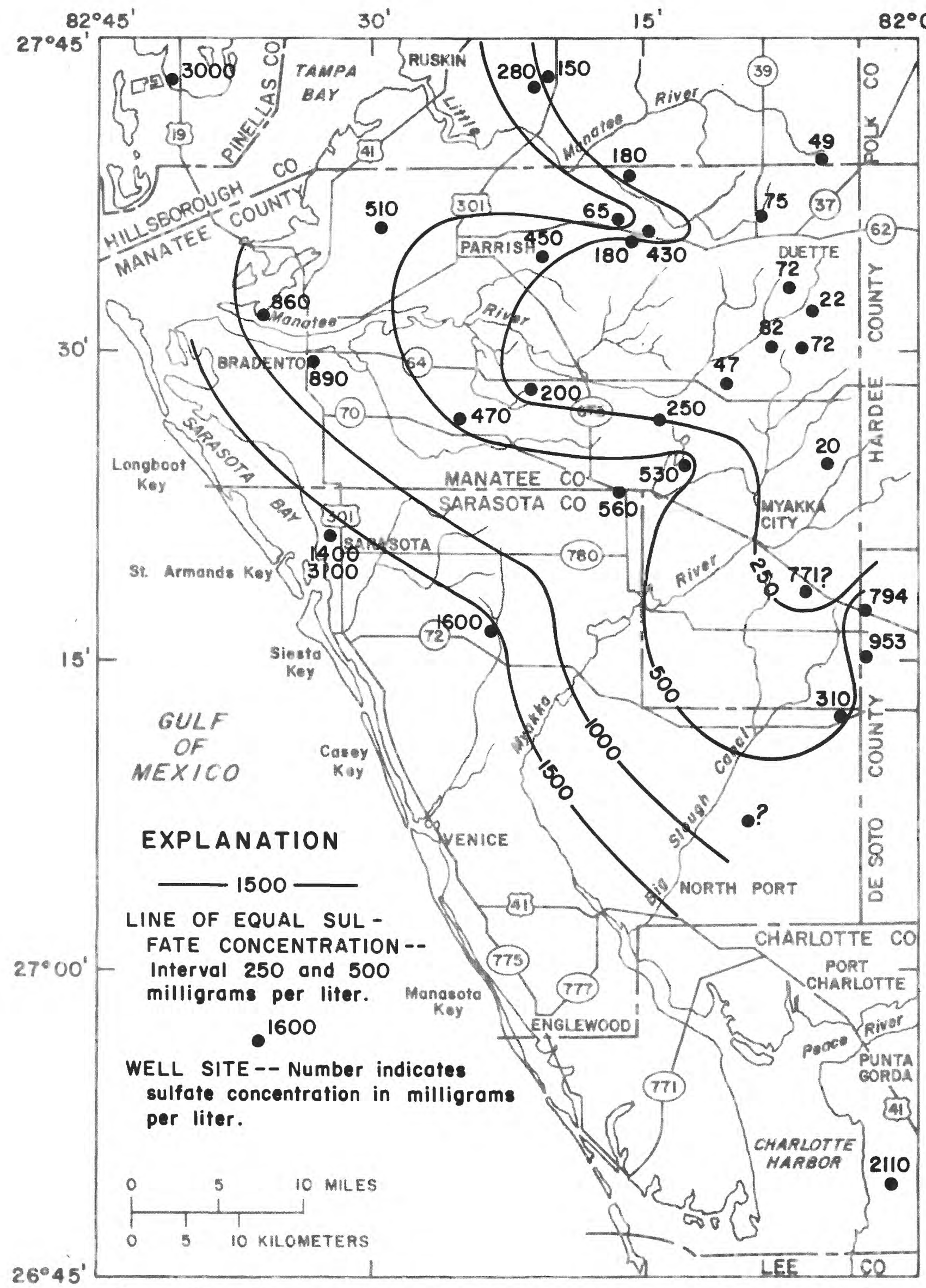

Figure 26.--Concentrations of sulfate in water from wells penetrating the lower zone of the Floridan aquifer. 


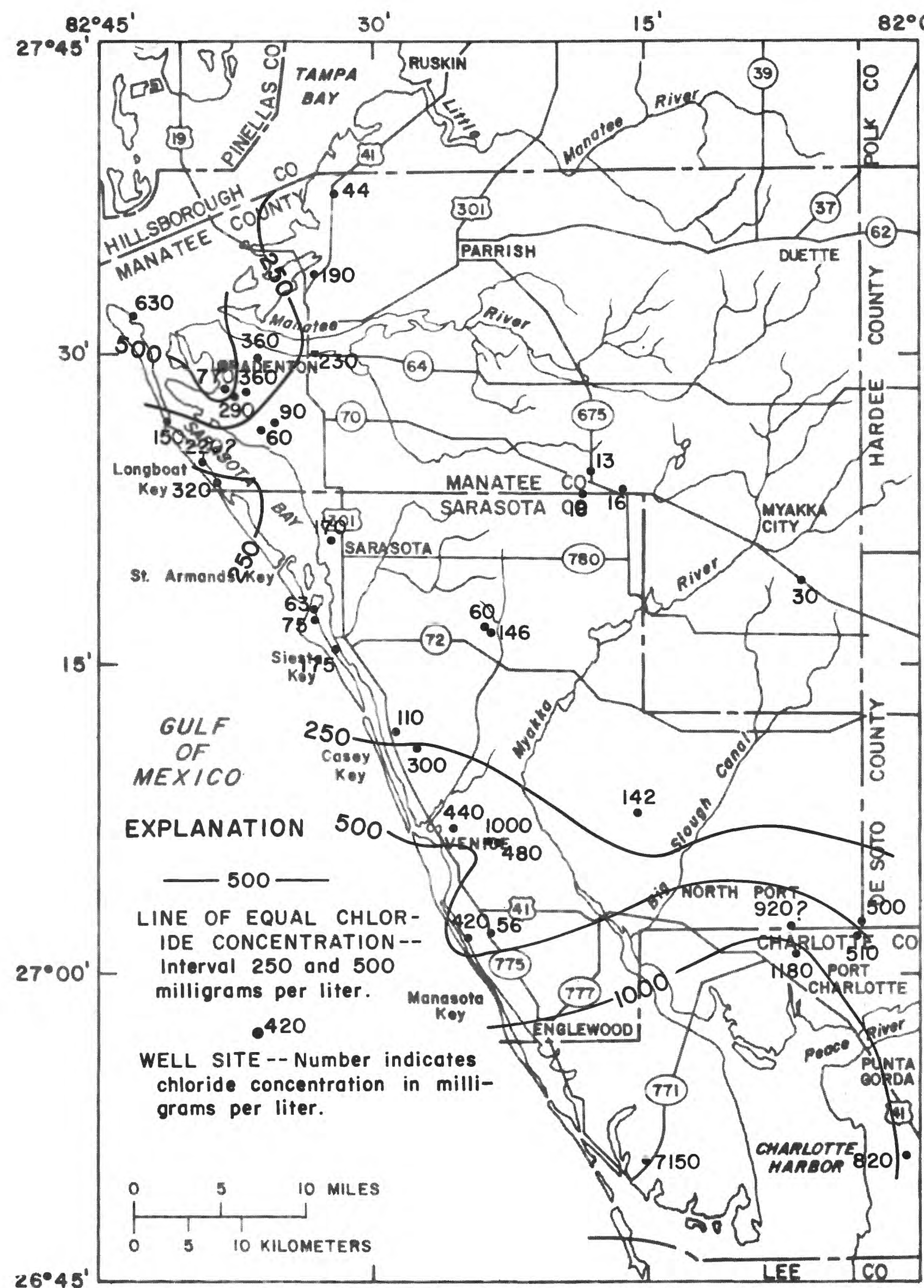

Figure 27.--Concentrations of çhloride in water from wells penetrating the upper zone of the Floridan aquifer. 


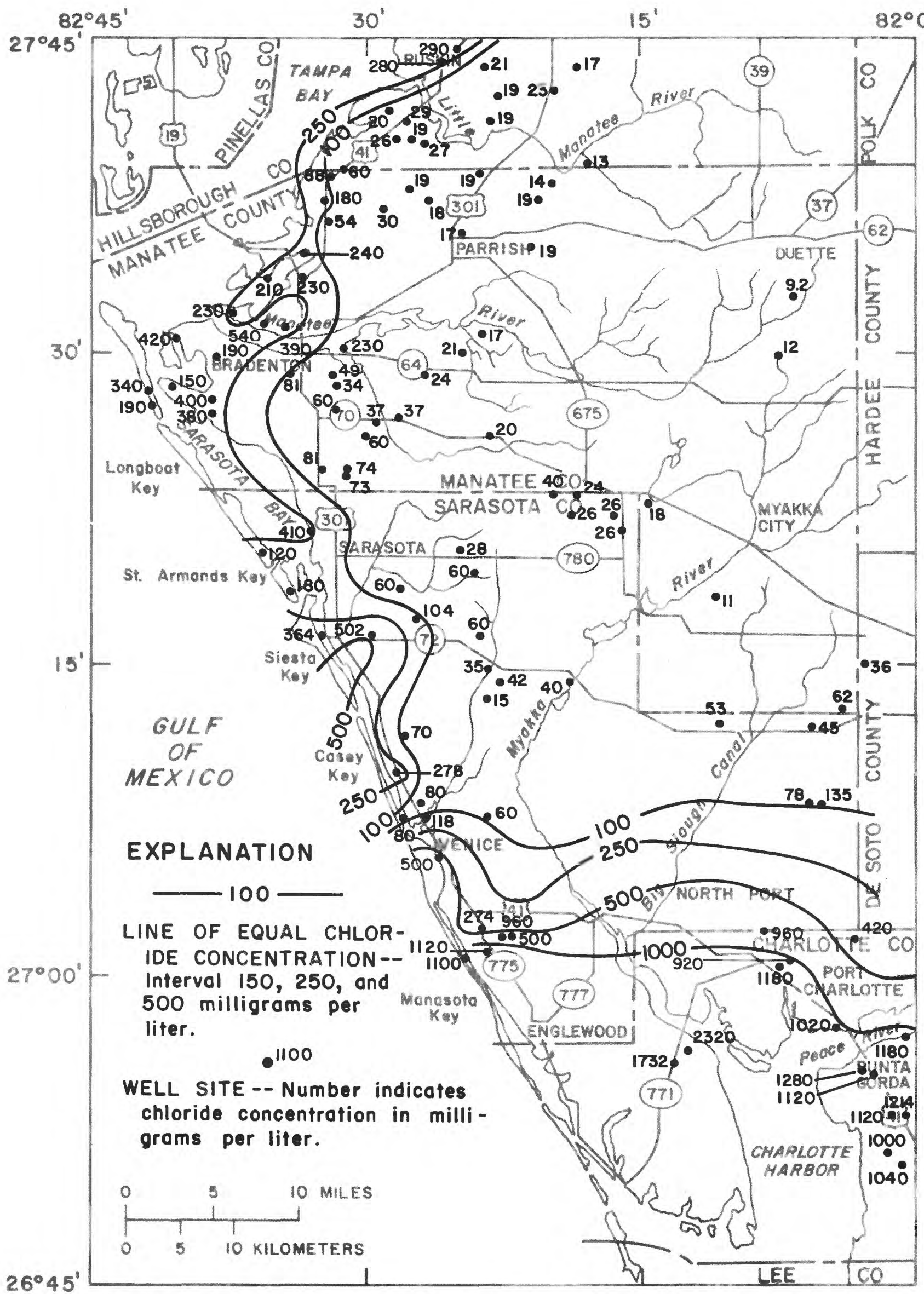

Figure 28.--Concentrations of chloride in water from wells penetrating the middle zone of the Floridan aquifer. 


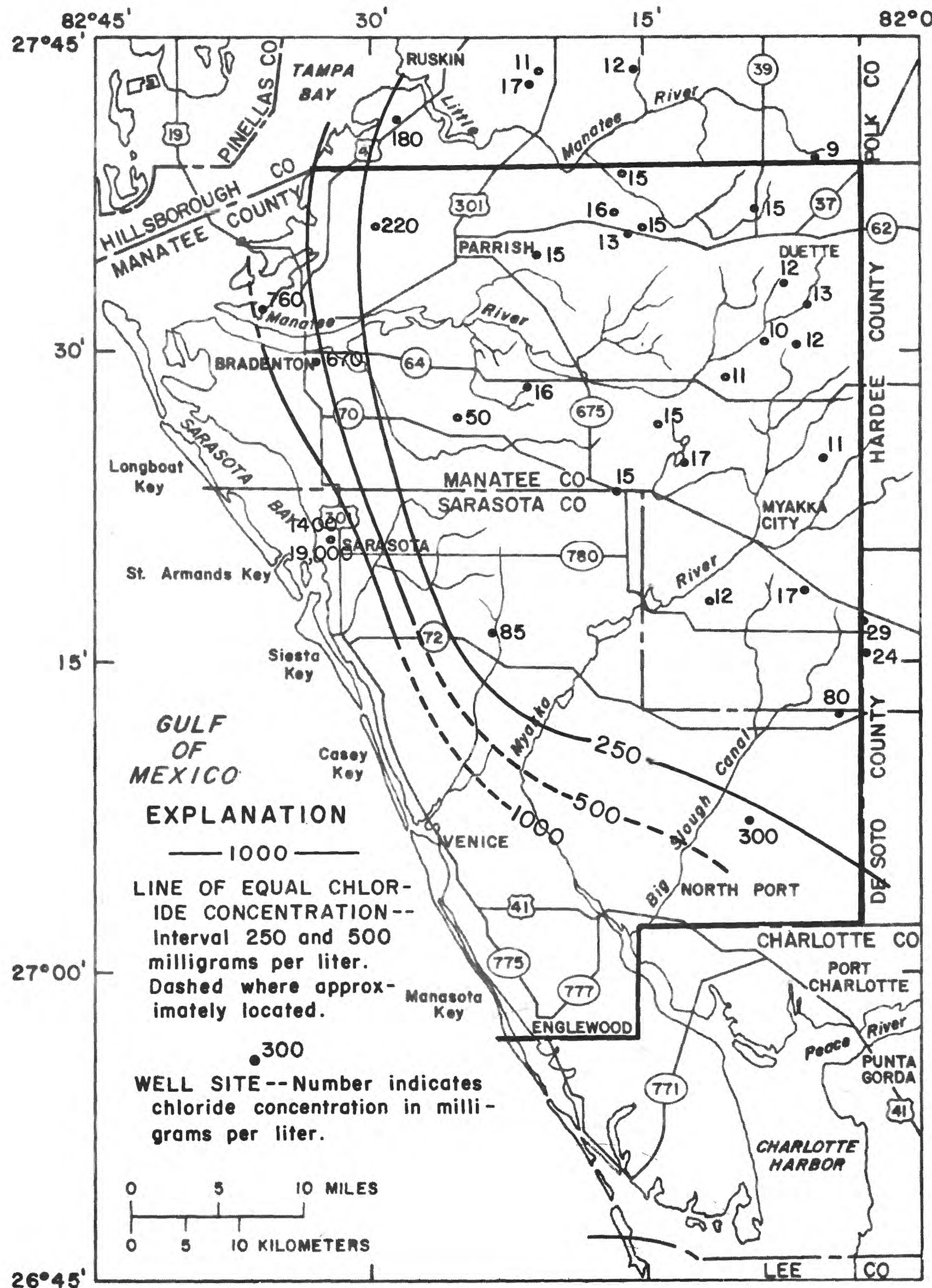

Figure 29.--Concentrations of chloride in water from wells penetrating the lower zone of the Floridan aquifer. 


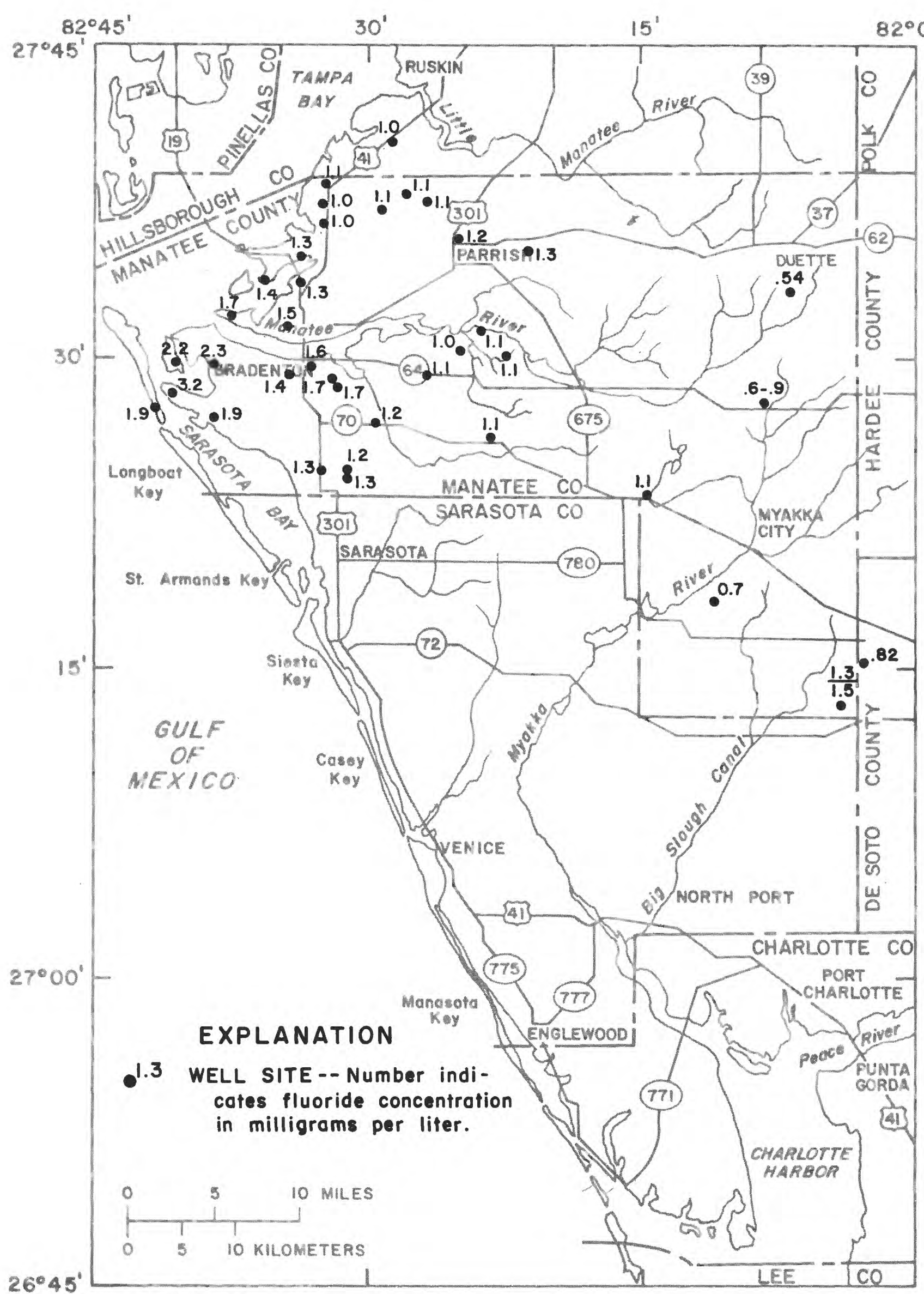

Figure 30.--Concentrations of fluoride in water from wells penetrating the middle zone of the Floridan aquifer. 


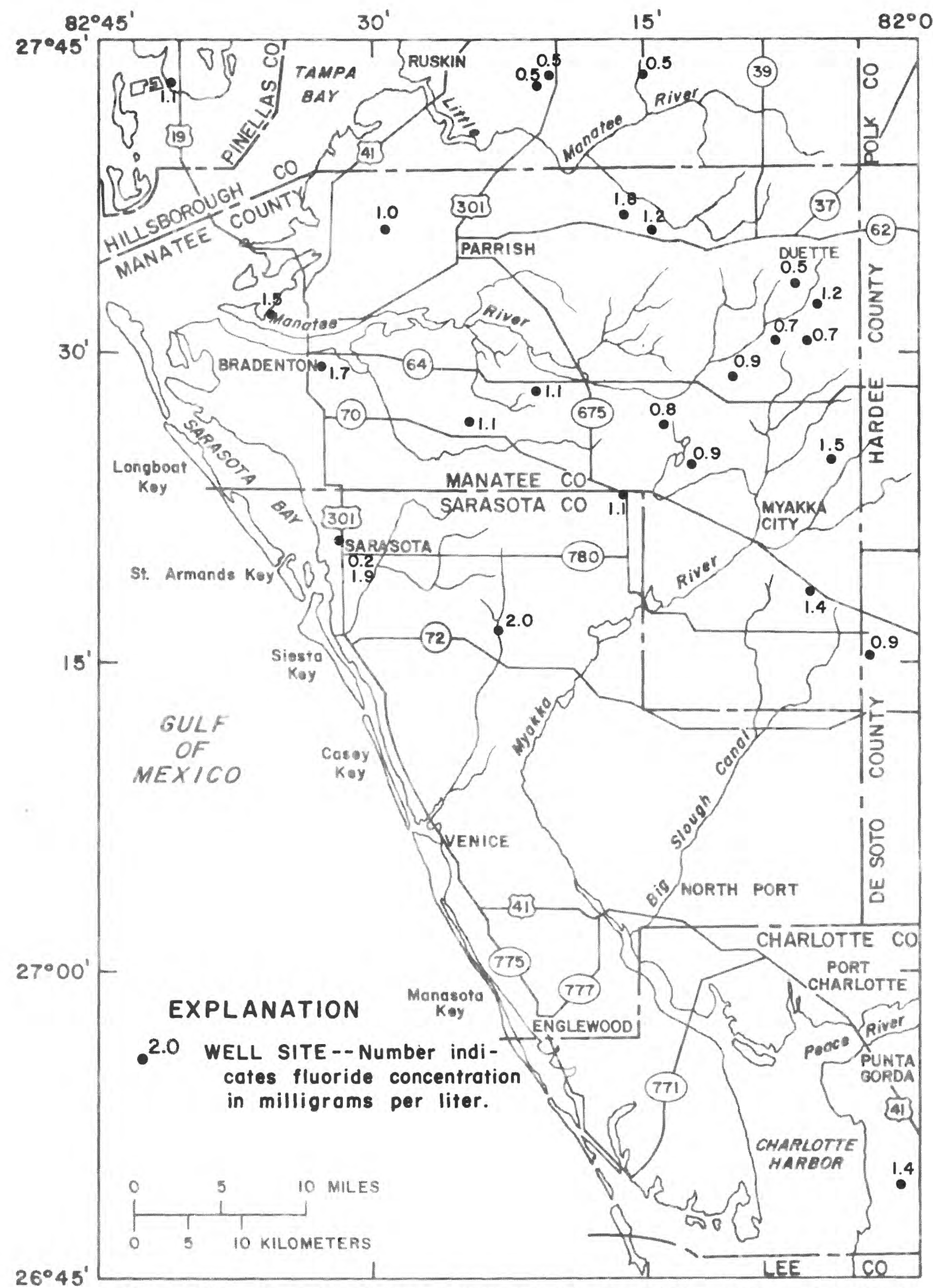

Figure 31.--Concentrations of fluoride in water from wells penetrating the lower zone of the Floridan aquifer. 
A knowledge of existing and projected water use in the Manasota Basin is essential in evaluating the hydrologic data network. Background information on water use was provided by statewide water-use surveys by the U.S. Geological Survey in 1970 and 1975 (Pride, 1973; Leach, 1977). Results from these surveys and additional information are summarized in table 6. Projected water-use information was obtained from government and consultant reports.

In 1970, an estimated $111 \mathrm{Mgal} / \mathrm{d}$ of surface and ground water were used. By 1975, water use increased to an estimated $118 \mathrm{Mgal} / \mathrm{d}$, and, by 1985 , the projected water use will be about $200 \mathrm{Mgal} / \mathrm{d}$. The major water uses are for irrigation and public supply.

Table 6.--Historical and projected water use in the Manasota Basin

[in million gallons per day]

\begin{tabular}{|c|c|c|c|c|c|c|c|}
\hline \multirow{2}{*}{ Year } & \multicolumn{3}{|c|}{ Public supply } & \multicolumn{2}{|c|}{$\begin{array}{l}\text { Industrial } \\
\text { self-supplied }\end{array}$} & \multicolumn{2}{|c|}{$\begin{array}{l}\text { Thermoelectric } \\
\text { power }\end{array}$} \\
\hline & $\begin{array}{l}\text { Population } \\
\text { served } \\
\text { (thousands) }\end{array}$ & $\begin{array}{l}\text { Ground } \\
\text { water }\end{array}$ & $\begin{array}{c}\text { Surface } \\
\text { water }\end{array}$ & $\begin{array}{l}\text { Ground } \\
\text { water }\end{array}$ & $\begin{array}{c}\text { Surface } \\
\text { water }\end{array}$ & $\begin{array}{l}\text { Ground } \\
\text { water }\end{array}$ & $\begin{array}{c}\text { Surface } \\
\text { water }\end{array}$ \\
\hline $1970^{1}$ & 169.1 & 11.3 & 9.9 & 10.6 & -- & -- & - \\
\hline $1975^{2}$ & 169.9 & 10.4 & $19.9 *$ & 5.0 & -- & -- & $25.0 * *$ \\
\hline $1985^{3}$ & & \multicolumn{2}{|c|}{58.2} & \multicolumn{2}{|c|}{34.4} & \multicolumn{2}{|c|}{15.0} \\
\hline $2000^{4}$ & & \multicolumn{2}{|c|}{119.5} & & & & \\
\hline
\end{tabular}

\begin{tabular}{|c|c|c|c|c|c|c|c|}
\hline \multirow{3}{*}{ Year } & \multicolumn{2}{|c|}{ Irrigation } & \multicolumn{5}{|c|}{ Self-supplied } \\
\hline & \multirow{2}{*}{$\begin{array}{l}\text { Ground } \\
\text { water }\end{array}$} & \multirow{2}{*}{$\begin{array}{c}\text { Surface } \\
\text { water }\end{array}$} & \multirow{2}{*}{$\begin{array}{l}\text { Population } \\
\text { served } \\
\text { (thousands) }\end{array}$} & \multicolumn{2}{|c|}{ Domestic } & \multicolumn{2}{|c|}{ Livestock } \\
\hline & & & & $\begin{array}{l}\text { Ground } \\
\text { water }\end{array}$ & $\begin{array}{c}\text { Surface } \\
\text { water }\end{array}$ & $\begin{array}{l}\text { Ground } \\
\text { water }\end{array}$ & $\begin{array}{c}\text { Surface } \\
\text { water }\end{array}$ \\
\hline $1970^{1}$ & 76.8 & 2.3 & -- & -- & -- & -- & -- \\
\hline $1975^{2}$ & 40.8 & 3.2 & 116.8 & 11.7 & -- & 2.0 & 0.5 \\
\hline $1985^{3}$ & $43.0^{5}$ & 52.1 & - & -- & -- & -- & -- \\
\hline $2000^{4}$ & $52.0^{5}$ & & & & & & \\
\hline
\end{tabular}

$1_{\text {Pride (1973). }}$

Leach (1977).

${ }_{4}^{3}$ Geraghty and Miller, Inc. (1977).

${ }_{5}^{4}$ Southwest Florida Water Management District (1978).

5 Wilson and Gerhart (1979).

*Includes $6 \mathrm{Mgal} / \mathrm{d}$ raw water for industrial purposes.

**Value represents water used in filling reservoir; actual operating usage is about $9.8 \mathrm{Mgal} / \mathrm{d}$. 
The major use of water in the area is for irrigation. Most irrigation occurs during the fall and winter-spring growing seasons, which are also the dry seasons. During the summer season, June through September, little or no irrigation is required. Daily water use when irrigation is required may be two to three times greater than when not required.

An estimated 40,800 acres were irrigated in 1975 (Leach, 1977). The principal crop types were citrus, vegetable, and pasture. Irrigated citrus and pasture acreage decreased markedly from 1970 to 1975, whereas vegetable and other acreage increased slightly. Water used for irrigation of citrus, vegetable, pasture, and other acreage was about $79 \mathrm{Mgal} / \mathrm{d}$ in 1970 and $44 \mathrm{Mgal} / \mathrm{d}$ in 1975. More than 90 percent of the water used for irrigation was obtained from groundwater sources, primarily from the Floridan aquifer.

By 1985, projected ground-water withdrawal for irrigation will average about $43 \mathrm{Mgal} / \mathrm{d}$, increasing to about $52 \mathrm{Mgal} / \mathrm{d}$ by 2000 (Wilson and Gerhart, 1979). The amount of surface water used for irrigation will remain the same or increase slightly.

\section{Public Supply}

Estimated water use for public supply was $21.2 \mathrm{Mgal} / \mathrm{d}$ in 1970 and $30.3 \mathrm{Mgal} / \mathrm{d}$ in 1975 (table 6). The major water suppliers are the Manatee County Utility System and the city of Bradenton in Manatee County and the city of Sarasota, Sarasota County Utility District No. 1, Venice, Venice Gardens, Englewood Water District, and North Port in Sarasota County. By 1985, demands are projected to average about $60 \mathrm{Mgal} / \mathrm{d}$, with a peak demand of $86 \mathrm{Mgal} / \mathrm{d}$. By 2000, demand should average about $120 \mathrm{Mgal} / \mathrm{d}$.

The Manatee County Utility System supplies water to the communities of Palmetto, Holmes Beach, Longboat Key, Anna Maria, and Bradenton Beach and partially supplies the city of Bradenton. The system in 1978 contracted to supply the Sarasota County Utility District No. 1 as much as $10 \mathrm{Mgal} / \mathrm{d}$. In 1975, the average daily pumpage totaled $15.9 \mathrm{Mgal} / \mathrm{d}$ with $9.9 \mathrm{Mgal} / \mathrm{d}$ serving an estimated 55,000 people and an additional 6.0 Mgal/d pumpage for industrial use. By 1985, the average daily supply will be an estimated $27.4 \mathrm{Mgal} / \mathrm{d}$ (table 7). The county system obtains its water from Lake Manatee Reservoir (Manatee River). The safe yield of the reservoir has been estimated at 27 to $30 \mathrm{Mgal} / \mathrm{d}$ during a drought of 20-year frequency (Donald J. Smally, written commun., March 13, 1978).

In 1975, the city of Bradenton supplied an average $3.83 \mathrm{Mgal} / \mathrm{d}$, including about $0.7 \mathrm{Mgal} / \mathrm{d}$ purchased from the Manatee County Utility System, to an estimated 25,000 people. The water was pumped from the Braden River at Ward Lake. Projected water demand for Bradenton in 1985 is $5.0 \mathrm{Mga} 1 / \mathrm{d}$.

The city of Sarasota supplied an estimated $7.1 \mathrm{Mgal} / \mathrm{d}$ to about 60,000 residents in 1975. The Floridan and intermediate aquifers underlying the Verna well field are the sources of ground water for Sarasota. The projected water demand in 1985 is $7.5 \mathrm{Mgal} / \mathrm{d}$. 
Table 7.--Historical and projected water use by selected utility systems

\begin{tabular}{|c|c|c|c|c|c|}
\hline \multirow{2}{*}{ Public supply } & \multirow{2}{*}{ Source } & \multicolumn{4}{|c|}{$\begin{array}{l}\text { Use } \\
(\mathrm{Mgal} / \mathrm{d})\end{array}$} \\
\hline & & $1975^{1}$ & $1977^{2}$ & $1980^{2}$ & $1985^{2}$ \\
\hline $\begin{array}{l}\text { Manatee County Utility } \\
\text { System }\end{array}$ & $\begin{array}{l}\text { Lake Manatee Reservoir } \\
\text { (Manatee River) }\end{array}$ & 9.9 & 19.1 & 22.2 & 27.4 \\
\hline City of Bradenton & $\begin{array}{l}\text { Ward Lake (Braden } \\
\text { River) }\end{array}$ & 3.8 & 4.0 & 4.5 & 5.0 \\
\hline City of Sarasota & $\begin{array}{l}\text { Verna we1l field, addi- } \\
\text { tional standby wells }\end{array}$ & 7.1 & 6.3 & 6.8 & 7.5 \\
\hline $\begin{array}{l}\text { Sarasota County Utility } \\
\text { District No. } 1\end{array}$ & $\begin{array}{l}\text { Manatee County Utility } \\
\text { System }\end{array}$ & -- & 5.6 & 9.0 & 13.8 \\
\hline Venice (city) & We11 field, 50 wells & 1.2 & 1.4 & 1.7 & 2.0 \\
\hline $\begin{array}{l}\text { Venice Gardens Utility } \\
\text { Corporation }\end{array}$ & Well field, 36 we11s & -- & 1.0 & 1.2 & 1.8 \\
\hline Englewood Water District & Well field, 48 wells & 1.0 & 1.1 & 1.7 & 2.5 \\
\hline $\begin{array}{l}\text { General Development } \\
\text { Utilities, Inc., } \\
\text { North Port }\end{array}$ & $\begin{array}{l}\text { Myakka-Hatchee River } \\
\text { (Big Slough) }\end{array}$ & 1.0 & -- & -- & -- \\
\hline
\end{tabular}

In 1975 , the estimated water use by the city of Venice was $1.2 \mathrm{Mgal} / \mathrm{d}$ for 17,000 residents. During 1977 , the actual demand averaged $2.1 \mathrm{Mgal} / \mathrm{d}$, but on $1 \mathrm{y}$ $1.4 \mathrm{Mgal} / \mathrm{d}$ was available for delivery. The surficial and intermediate aquifers are the sources of water. As of 1978, the city operated a reverse-osmosis water treatment plant that has a $2 \mathrm{Mgal} / \mathrm{d}$ capacity. Projected water use in 1985 is $2.0 \mathrm{Mgal} / \mathrm{d}$.

Venice Gardens Utility Corporation, serving the Venice Garden area, obtains an estimated $1.0 \mathrm{Mgal} / \mathrm{d}$ (1977) from 36 wells tapping the intermediate aquifers. Projected water demand in 1985 is $1.8 \mathrm{Mgal} / \mathrm{d}$.

The Englewood Water District supplied an estimated $1.0 \mathrm{Mgal} / \mathrm{d}$ to a population of 10,000 in 1975. Two existing well fields (estimated capacity of 2.6 Mga1/d) withdraw water from the surficial and intermediate aquifers, and a proposed third well field will increase the water district's capacity to an estimated $6.4 \mathrm{Mgal} / \mathrm{d}$.

In 1975, General Development Utilities, Inc., delivered an estimated 1.0 $\mathrm{Mgal} / \mathrm{d}$ to about 5,000 people in the North Port area. The source of water was the Myakka-Hatchee River (Big Slough). 
Florida Power and Light's Manatee Powerplant in northern Manatee County is the only operating thermoelectric powerplant in the Basin. The plant uses (1978) an estimated $9.8 \mathrm{Mgal} / \mathrm{d}$ diverted from the Little Manatee River for its cooling system. In 1975, the plant used an estimated $25 \mathrm{Mgal} / \mathrm{d}$ primarily for filling the cooling pond (table 6). By 1985, the amount of water used for condenser cooling at the thermoelectric powerplant is estimated to be $15 \mathrm{Mgal} / \mathrm{d}$.

Estimates of self-supplied industrial water use were $10.6 \mathrm{Mgal} / \mathrm{d}$ in 1970 and $5.0 \mathrm{Mgal} / \mathrm{d}$ in 1975 (table 6). With the expansion of phosphate mining into the Basin (Manatee County only), the amount of water for industrial use is expected to increase considerably. The projected industrial water use in 1985 is 34.4 Mgal/d (Southwest F1orida Water Management District, 1978), $27.8 \mathrm{Mgal} / \mathrm{d}$ of this withdrawal will be for phosphate mining. By 2020, water use is expected to decrease to $10.6 \mathrm{Mgal} / \mathrm{d}$ as some areas become mined out.

In 1975 , the self-supplied rural domestic population of 116,800 used an estimated $11.7 \mathrm{Mgal} / \mathrm{d}$. An additional $2.5 \mathrm{Mgal} / \mathrm{d}$ was used for watering livestock.

\section{HYDROLOGIC DATA NETWORK ASSESSMENT}

The objective of a hydrologic data network is to provide information needed for the optimum utilization and management of water resources. The different uses for water data have been classified into four general categories: (1) current use; (2) planning and design; (3) long-term trends; and (4) the hydrologic environment. Each category and major use of the data are listed below (modified from Rabon, 1970).

\begin{tabular}{|c|c|}
\hline Category & Data use \\
\hline Current use & $\begin{array}{l}\text { Water management assessment of current availability } \\
\text { of water. } \\
\text { Water-quality control. } \\
\text { Forecasting of extreme streamflow events. } \\
\text { Monitoring seasonal potentiometric surface fluctua- } \\
\text { tions. } \\
\text { Monitoring and surveillance for legal requirements. }\end{array}$ \\
\hline Planning and design & $\begin{array}{l}\text { Reservoir storage. } \\
\text { Well-field development. } \\
\text { Irrigation (supplies and systems). } \\
\text { Waste dilution and storage. } \\
\text { Bridge and culvert design. }\end{array}$ \\
\hline Long-term trends & $\begin{array}{l}\text { Background or baseline information to determine } \\
\text { changes in the hydrologic environments. } \\
\text { Determine statistics of streamflow and changes with } \\
\text { time. }\end{array}$ \\
\hline Hydrologic environment & $\begin{array}{l}\text { Hydrologic studies. } \\
\text { Planning, design, and operation of systems contro1- } \\
\text { ling water pollution. } \\
\text { Appraisal of changing land use effects on the hydro- } \\
\text { logic environments. }\end{array}$ \\
\hline
\end{tabular}


Historically, hydrologic data collection and research programs in Florida were developed by the U.S. Geological Survey and its cooperators in response to local needs. The program. has. grown rapidly to meet the increased demand for water information brought about by urbanization, extreme hydrologic conditions, saltwater intrusion, industrial expansion, and problems associated with pollution and the hydrologic environment. Some principal programs, investigations, and types of data collected in and near the Manasota Basin are discussed below.

\section{Surface Water}

The first systematic program of collecting continuous streamflow data in the Manasota Basin and adjacent areas began in the 1930's with the establishment of three continuous-record stations: Myakka River near Sarasota (1936), Manatee-River near Bradenton (1939), and Little Manatee River near Wimauma (1939). This was part of the statewide program developed by the Geological Survey and the State of Florida to evaluate the water resources of the state. In the 1950's and 1960's, additional continuous-record stations and a partialrecord network were established.

In the early 1960's, an extensive network of continuous, low-flow, partialrecord, and miscellaneous measurement stations was established in the Myakka River basin area in conjunction with a study to appraise the water resources of the area (Flippo and Joyner, 1968; Joyner and Sutcliffe, 1976). Most of these stations were discontinued in 1965.

In 1974, a flood-evaluation study was made of the Myakka River basin. Profiles of floods having recurrence intervals of $2,5,10,25,50,100,200$, and 500 years were estimated for the nontidal part of a 45-mile reach of the Myakka River main stem (natural and diked conditions) and selected tributaries (Hammett and others, 1978). Flood profiles are plots of water-surface elevation at flood stages versus stream distance, measured in the upstream direction. Recurrence interval is the average interval of time within which a flood of specific magnitude is expected to be equaled or exceeded.

\section{Ground Water}

In 1930, an intensive investigation began of the ground-water resources of Florida (Stringfield, 1933a). From 1930 to 1932, periodic water-leve1 measurements were made, and water from selected wells was sampled to determine the chemical quality. Most of the work was done in Sarasota, Manatee, Orange, Duval, and Pinellas Counties (Stringfield, 1936). A detailed study of the ground-water resources in Sarasota County was conducted at the same time (Stringfield, 1933b).

From 1950 to 1955, a study was made of the ground-water resources of Manatee County (Peek and Anders, 1955; Peek, 1958a). Numerous wells were inventoried, continuous and periodic water-level measurements were made, and chemical quality of water from wells tapping selected water-bearing formations was determined. After completion of the study, water levels in selected wells were measured continuously until the late $1950^{\prime}$ 's and in one well until the mid-1960's. 
From 1963 to 1966, a detailed study of the water resources of the Myakka River basin was made by Joyner and Sutcliffe (1976). During the investigation, records of about 400 wells were collected, including water-level measurements, well construction, and drillers' and geophysical logs. Chemical quality of water was determined from selected water-bearing zones.

Potentiometric surface maps of the Floridan aquifer showing water levels throughout the Southwest Florida Water Management District were produced in January 1964 and in May 1969, 1971, 1973, and each year since, and in September since 1975. Maps showing changes in the potentiometric surface for the periods January 1964 to May 1969 and May 1969 to May 1975 have been published and are scheduled every 5 years (Stewart and others, 1971; Mills and Laughlin, 1976). The January 1964 and May 1969 maps and the 1964 to 1969 change in potentiometric surface map, however, did not include the Manasota Basin.

The water table in the surficial aquifer and the potentiometric surface of the Floridan aquifer in selected well fields in west-central Florida were measured, and contour maps were produced semiannually in 1971 and 1972, quarterly from 1973 to 1975, and again semiannually since 1976 (Wolansky and others, 1978). The Verna well field in northern Sarasota County was first included in the May 1977 maps when the Manasota Basin was included in the Southwest Florida Water Management District in January 1977.

In 1975, the Regional Observation Monitor-Well Program (ROMP) was implemented by the Southwest Florida Water Management District. The specific objectives of ROMP involve studies of (1) hydrologic properties of the aquifers and confining beds, (2) the potentiometric surface of the intermediate aquifers and the Floridan aquifer and the water table of the surficial aquifer, (3) groundwater quality and seawater intrusion, and (4) relation between climate and ground water (Gomberg, 1975). The proposed monitoring network consists of 18 well sites and 5 transects (fig. 32). Each well site contains one or more wells open to specific aquifers or water-bearing zones, and each transect consists of two or more wells and also includes one of the proposed monitoring well sites. As of August 1978, one well site (No. 32) had been completed in the Manasota Basin.

\title{
Existing Network
}

\author{
Surface Water
}

Surface-water data for the Manasota Basin consist of stage, discharge, and water quality of streams and stage and water quality of reservoirs. Table 8 lists stations operated by the U.S. Geological Survey in cooperation with local, state, and federal agencies and the type and frequency of data collection.

The streamflow data network consists of continuous-record, partial-record, and miscellaneous measurement stations. Partial-record stations include creststage and low-flow stations.

There are three continuous-record streamflow stations operated in the Manasota Basin. They are the Myakka River at Myakka City, Myakka River near Sarasota, and Manatee River near Myakka Head (table 8). A continuous-record station adjacent to the Manasota Basin is the Little Manatee River near Wimauma. 


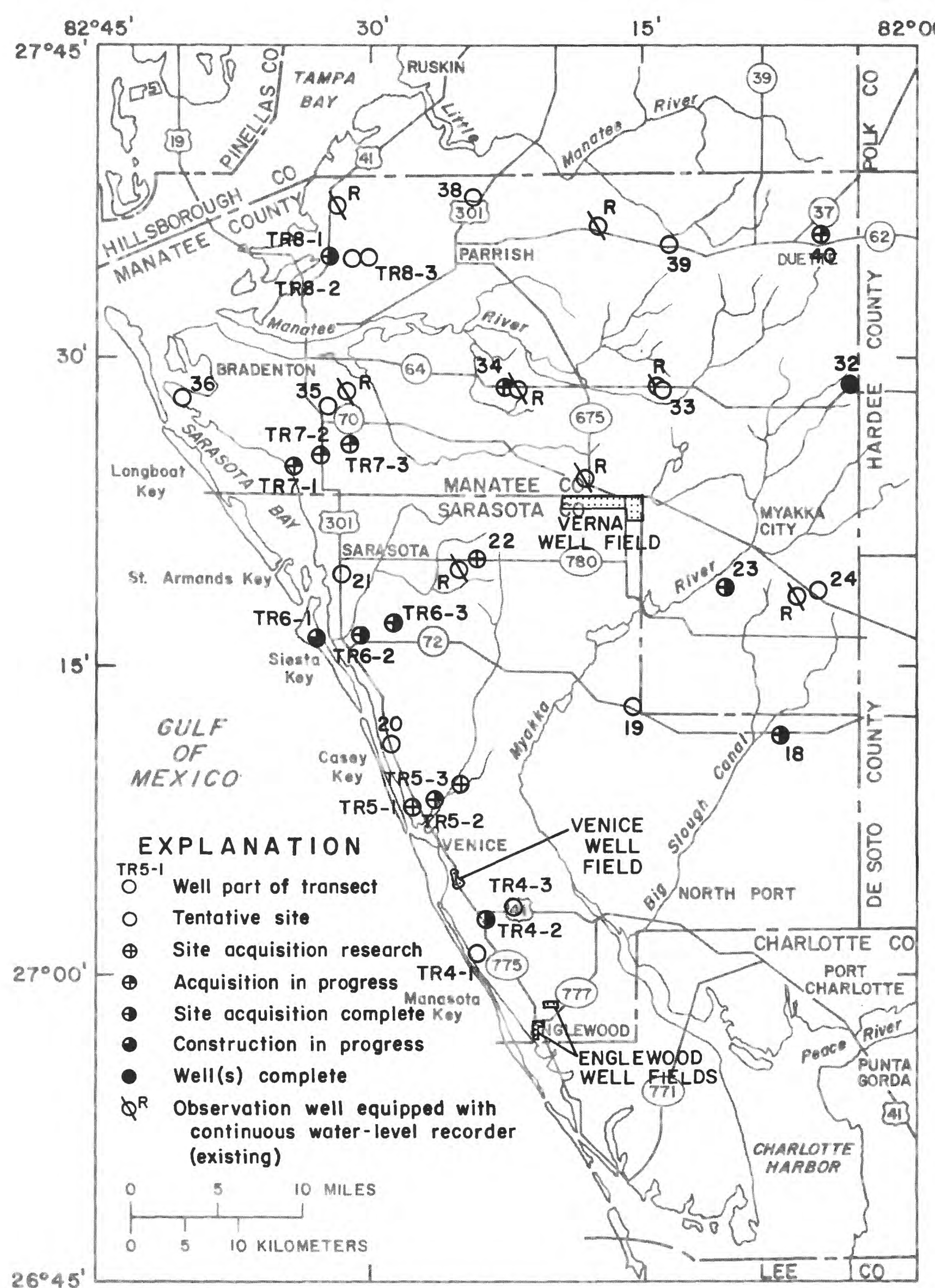

Figure 32.--Location of proposed sites and transects and regional observation monitor-we11 network as of 1978. 


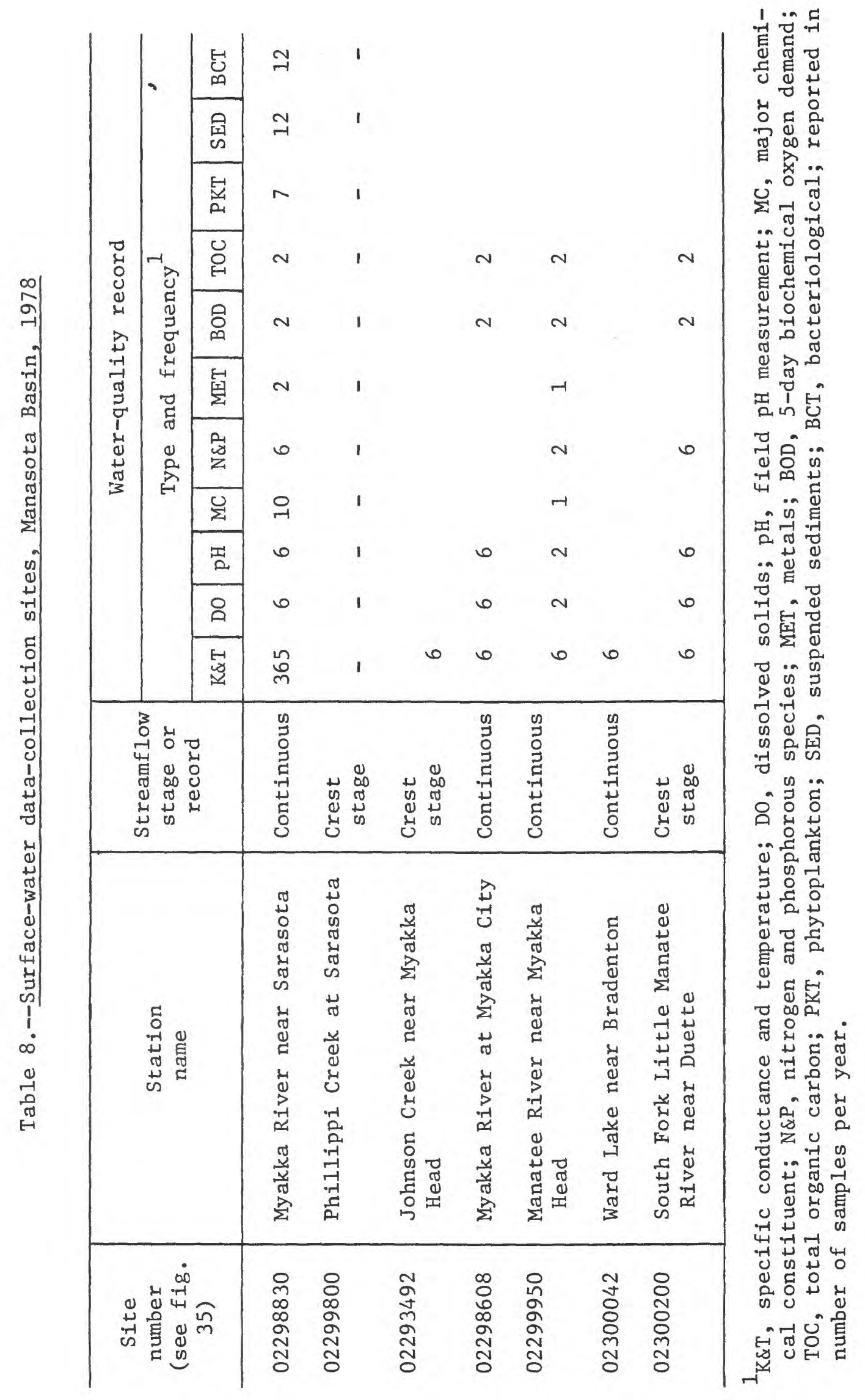


There are three crest-stage, partial-record stations within the Manasota Basin where annual maximum flood levels are observed (table 8). They are Johnson Creek near Myakka Head, Phillippi Creek at Sarasota, and South Fork Little Managee River near Duette.

At low-flow partial-record stations, periodic measurements of base-flow discharge are obtained normally about two or three times per year. However, there are no active low-flow partial-record stations in the Basin.

The U.S. Geological Survey operates a gaging station on Ward Lake near Bradenton. Stage is recorded continuously and lake discharge measurements made twice yearly. A gaging station at Lake Manatee Reservoir is operated by Manatee County; reservoir stage is recorded three times daily.

\section{Ground Water}

For 1978, ground-water data for the Basin include water-level data from 40 wells equipped with continuous recorders (fig. 33) and from 4 wells where water levels are measured bimonthly. In May and September, water levels are measured in about 58 wells that are open to the intermediate and Floridan aquifers (fig. 33). Data are used to prepare potentiometric surface maps of the Floridan aquifer in the Water Management District.

Water levels in observation wells within and near the Verna well field are measured continuously in some wells and semiannually in others (May and September). The data are included in semiannual data reports published by the U.S. Geological Survey. Figure 34 shows the altitude of the water table in the surficial aquifer and potentiometric surface of the Floridan aquifer in May 1978.

As of 1978, more than 80 wells in Sarasota County had been sampled for major constituents and radiochemical analysis in cooperation with Sarasota County (H. Sutcliffe, written commun., 1978). In conjunction with an investigation of the location and movement of the saltwater-freshwater interface in the Floridan aquifer, a salinity-monitoring network has been designed for the Southwest Florida Water Management District and will include about 17 wells open to the Floridan aquifer in the Manasota Basin (W. C. Steinkampf, written commun., 1978).

\section{Evaluation and Modification of Data Network}

\section{Surface Water}

Rabon (1970) discusses in detail four general categories of hydrologic data in relation to the streamflow data program in Florida (table 9). His discussion and evaluation of the streamflow data network are applicable to the Manasota Basin. Rabon stated that, with few exceptions, the goals of the data program could not be met by generalization of data for a gaged basin by regression analysis.

The Myakka River near Sarasota station was classified as meeting the need for current-use data (Rabon, 1970). Extended periods of zero flow or low flow, however, limit its value in correlation with nearby streams. 


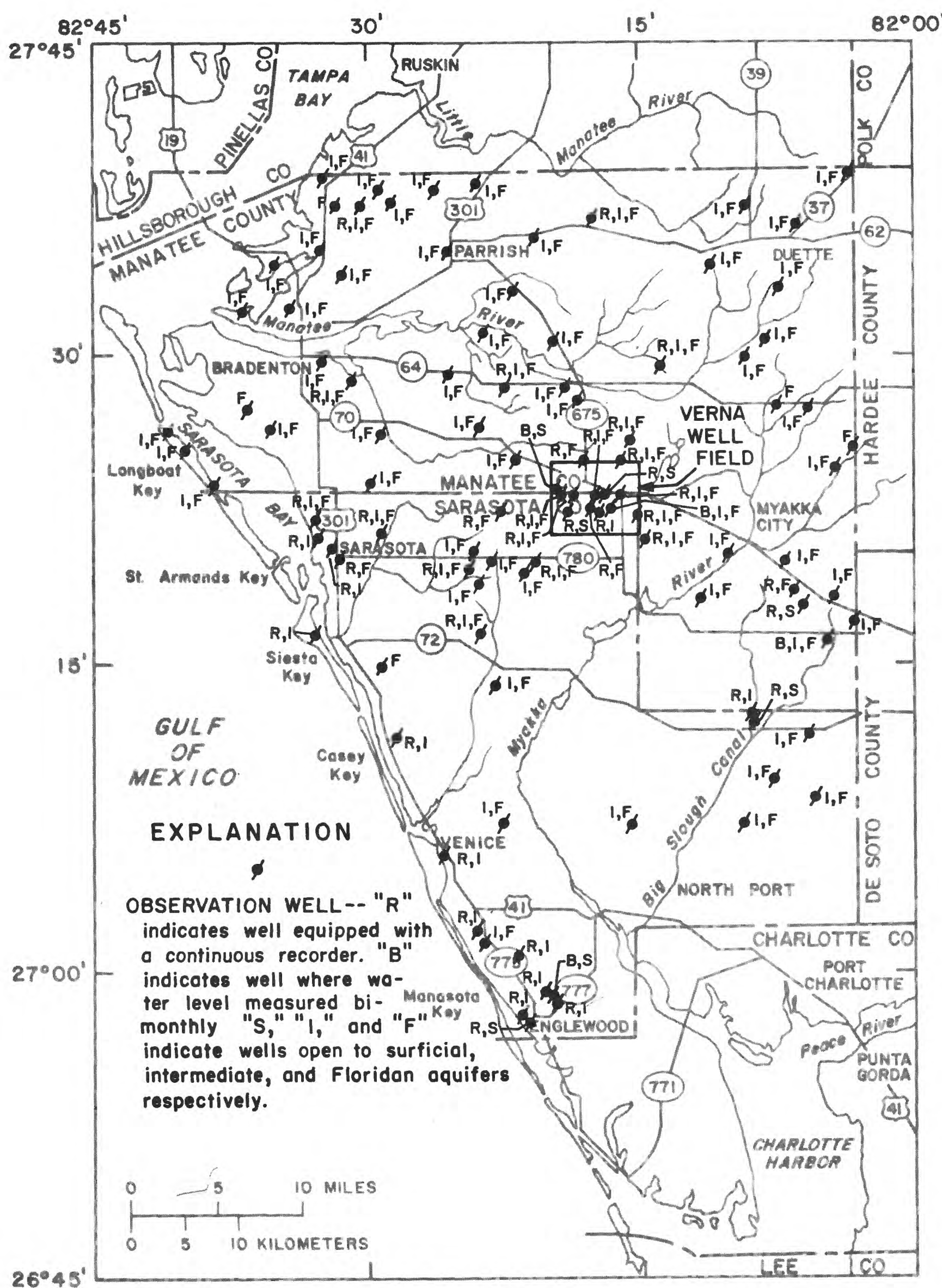

Figure 33.--Observation-we11 network. 


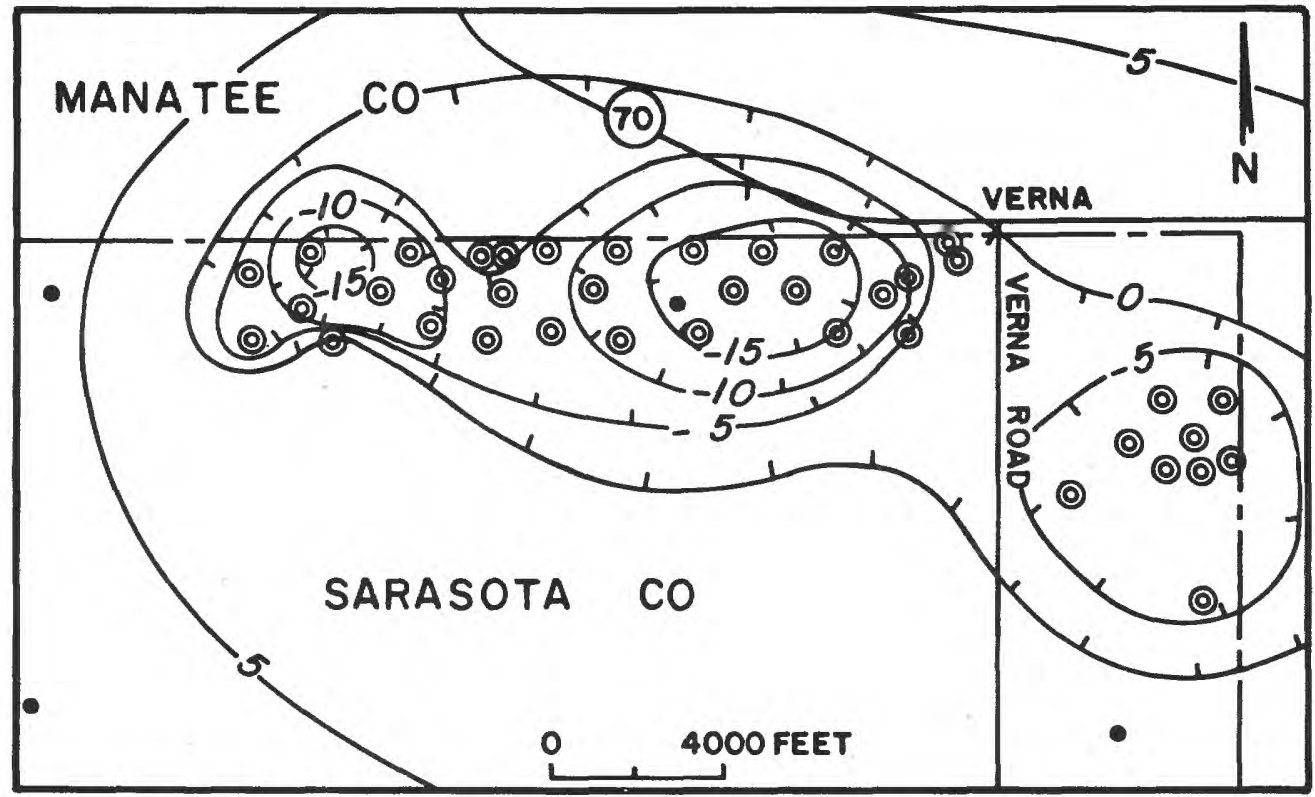

VERNA WELL FIELD MAY 16 PUMPAGE $8.6 \mathrm{MgOI} / \mathrm{d}$

(POTENTIOMETRIC SURFACE OF UPPER FLORIDAN AQUIFER)

EXPLANATION

- 5- POTENTIOMETRIC CONTOUR--Shows altitude at which water level would have stood in tightly cased wells. Interval 5 feet. Datum is National Geodetic Vertical Dotum of 1929.

(2) Municipal supply well

- Observation well

WATER TABLE

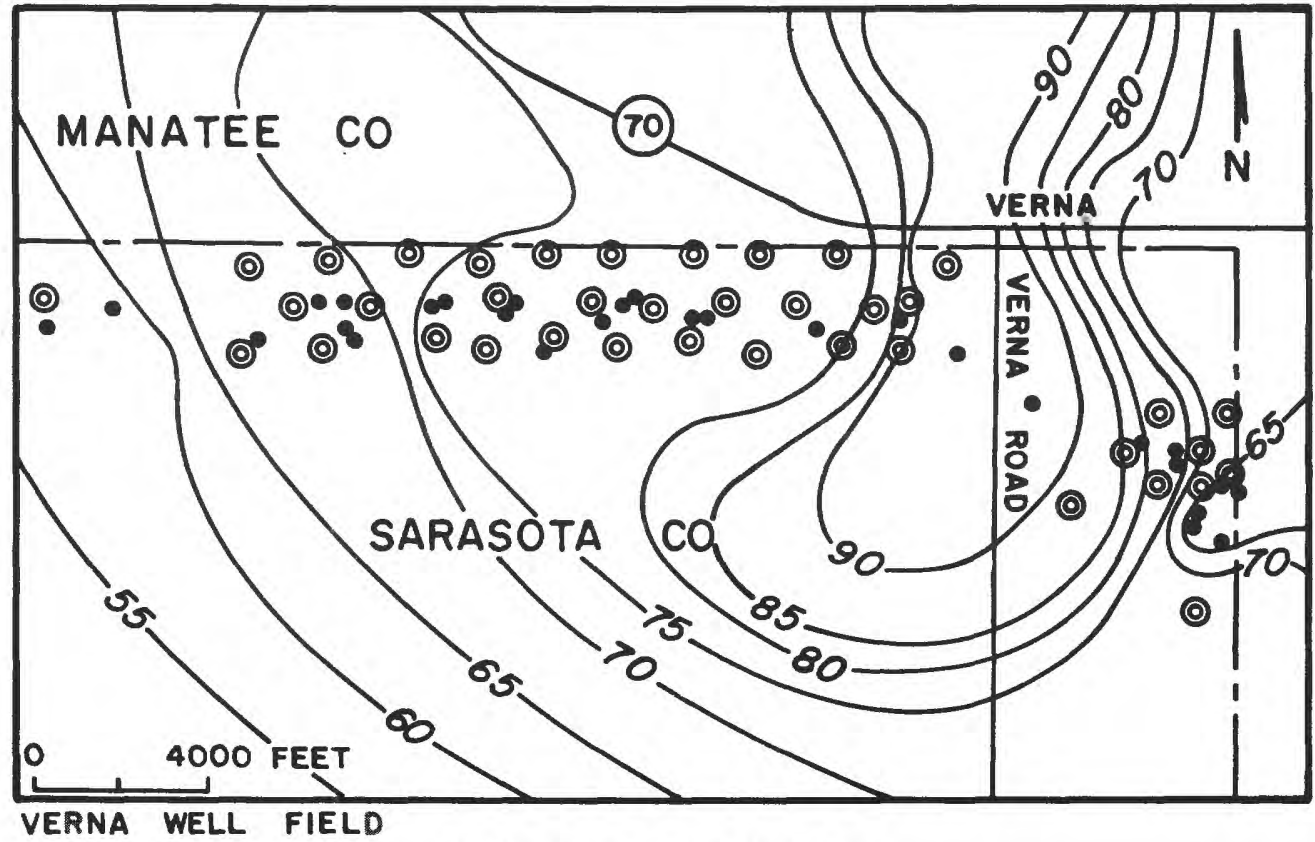

EXPLAN A T ION

-55- WATER-TABLE CONTOUR--Shows altitude of water table. Interval 5 feet. Datum is National Geodetic Vertical Datum of 1929.

(2) Municipal supply well - Observation well

Figure 34.--Potentiometric surface of the Floridan aquifer and water table of the surficial aquifer, Verna well field, Sarasota County, May 1978 (from Wolansky and others, 1978). 
Table 9.--Framework for design of a

[after

\begin{tabular}{|c|c|c|c|}
\hline Type of & \multirow{3}{*}{ Current } & \multicolumn{2}{|c|}{ Planning and design } \\
\hline & & \multicolumn{2}{|c|}{$\begin{array}{c}\text { Natural flow } \\
\text { (Low-flow frequency or flood frequency) }\end{array}$} \\
\hline & & Minor streams & Principal streams \\
\hline Goals & $\begin{array}{l}\text { To provide current } \\
\text { data on streamflow } \\
\text { needed for day-by- } \\
\text { day decisions on } \\
\text { water management } \\
\text { as required. }\end{array}$ & \multicolumn{2}{|c|}{$\begin{array}{l}\text { To provide information on statistical } \\
\text { any stream to the specified accuracy. }\end{array}$} \\
\hline $\begin{array}{l}\text { Drainage area } \\
\text { limits. }\end{array}$ & Full range. & Less than $500 \mathrm{mi}^{2}$ & $\begin{array}{l}\text { Greater than } 500 \\
\mathrm{mi}^{2} \text {. }\end{array}$ \\
\hline Accuracy goal. & As requested. & $\begin{array}{l}\text { Equivalent to } 10 \\
\text { years of record. }\end{array}$ & $\begin{array}{l}\text { Equivalent to } 25 \\
\text { years of record. }\end{array}$ \\
\hline Approach. & $\begin{array}{l}\text { Operate gaging } \\
\text { stations as re- } \\
\text { quested to provide } \\
\text { specific informa- } \\
\text { tion needed. }\end{array}$ & $\begin{array}{l}\text { Relate flow char- } \\
\text { acteristics to } \\
\text { drainage basin } \\
\text { characteristics } \\
\text { using data for } \\
\text { gaged basins. }\end{array}$ & $\begin{array}{l}\text { Operate gaging } \\
\text { stations to obtain } \\
25 \text { years of record } \\
\text { (or the equivalent } \\
\text { by correlation) at } \\
\text { a network of points } \\
\text { on principal } \\
\text { streams; interpo- } \\
\text { late between points. }\end{array}$ \\
\hline $\begin{array}{l}\text { Evaluate avail- } \\
\text { able data. }\end{array}$ & $\begin{array}{l}\text { Identify stations } \\
\text { where data is used } \\
\text { currently and code } \\
\text { the specific use } \\
\text { of data. }\end{array}$ & $\begin{array}{l}\text { Develop relation- } \\
\text { ship for each flow } \\
\text { characteristic and } \\
\text { compare standard } \\
\text { error with accu- } \\
\text { racy goal. Eval- } \\
\text { uate sample. }\end{array}$ & $\begin{array}{l}\text { Lay out network of } \\
\text { points on princi- } \\
\text { pal streams and } \\
\text { compare data avail- } \\
\text { able at these } \\
\text { points with goal. }\end{array}$ \\
\hline Design future. & & \multicolumn{2}{|c|}{$\begin{array}{l}\text { Identify goals that have not been at- } \\
\text { tained. Consider alternate means of } \\
\text { attaining goals. Identify elements of } \\
\text { future program. }\end{array}$} \\
\hline
\end{tabular}


surface-water data-collection program

Rabon, 1970]

\begin{tabular}{|c|c|c|c|}
\hline \multicolumn{2}{|c|}{ Planning and design--continued } & \multirow{3}{*}{ Long-term trends } & \multirow{3}{*}{ Stream envi ronment } \\
\hline \multicolumn{2}{|c|}{$\begin{array}{l}\text { Regulated flow } \\
\text { (Low-flow frequency or flood frequency) }\end{array}$} & & \\
\hline Minor streams & Principal streams & & \\
\hline \multicolumn{2}{|c|}{ characteristics of flow at any site on } & $\begin{array}{l}\text { To provide a long- } \\
\text { term data base of } \\
\text { homogeneous rec- } \\
\text { ords on natural- } \\
\text { flow streams. }\end{array}$ & $\begin{array}{l}\text { To describe the } \\
\text { hydrologic envi- } \\
\text { ronment of stream } \\
\text { channels and drain- } \\
\text { age basins. }\end{array}$ \\
\hline Less than $500 \mathrm{mi}^{2}$. & $\begin{array}{l}\text { Gręater than } 500 \\
\mathrm{mi}^{2} \text {. }\end{array}$ & Fu11 range. & Full range. \\
\hline $\begin{array}{l}\text { Equivalent to } 10 \\
\text { years of record. }\end{array}$ & $\begin{array}{l}\text { Equivalent to } 25 \\
\text { years of record. }\end{array}$ & Highest obtainable. & As required. \\
\hline $\begin{array}{l}\text { Develop general- } \\
\text { ized relations } \\
\text { that account for } \\
\text { the effect of stor- } \\
\text { age, diversion, or } \\
\text { regulation on nat- } \\
\text { ural flow charac- } \\
\text { teristics. }\end{array}$ & $\begin{array}{l}\text { Utilize analytical } \\
\text { model of stream } \\
\text { system with ob- } \\
\text { served data as in- } \\
\text { put to compute } \\
\text { homogeneous rec- } \\
\text { ords for both nat- } \\
\text { ural flow condi- } \\
\text { tions and present } \\
\text { conditions of de- } \\
\text { velopment. }\end{array}$ & $\begin{array}{l}\text { Operate a number } \\
\text { of carefully se- } \\
\text { lected gaging sta- } \\
\text { tions indefinitely }\end{array}$ & $\begin{array}{l}\text { Observe and pub- } \\
\text { lish information } \\
\text { on stream environ- } \\
\text { ment. }\end{array}$ \\
\hline $\begin{array}{l}\text { Appraise type of } \\
\text { regulation, data } \\
\text { available, and } \\
\text { areas where rela- } \\
\text { tionships are } \\
\text { needed. }\end{array}$ & $\begin{array}{l}\text { Identify stream } \\
\text { systems that } \\
\text { should be studied } \\
\text { using model ap- } \\
\text { proach and deter- } \\
\text { mine data require- } \\
\text { ments. }\end{array}$ & $\begin{array}{l}\text { Select two sta- } \\
\text { tions in each WRC } \\
\text { subregion to op- } \\
\text { erate indefinitely } \\
\text { for this purpose. }\end{array}$ & $\begin{array}{l}\text { Evaluate informa- } \\
\text { tion available in } \\
\text { relation to goals. }\end{array}$ \\
\hline
\end{tabular}


The Manatee River near Myakka Head station was categorized as a planning and design station to be continued until improved methods of estimating streamflow characteristics have been developed (Rabon, 1970). Land-use changes within the river basin and potential stream impoundments may require reassessment of the type and use of the data collected at the station.

Regional relations were developed for estimating the magnitude and frequency of floods on streams in the Southwest Florida Water Management District area (Seijo and others, 1979). These relations are appligable to streams having drainage areas greater than $10 \mathrm{mi}^{2}$ but less than $2,500 \mathrm{mi}^{2}$ and that are not significantly affected by regulation, tides, or urbanization.

A major shortcoming of the existing streamflow data network is the lack of low-flow, partial-record stations. Land-use changes, such as urbanization, phosphate mining, and impoundment of streams, may affect low-flow characteristics. Agriculture and irrigation practices may also affect low-flow characteristics since peak periods of irrigation occur during periods of low flow.

Rabon (1970) stated that low-flow characteristics (mean 7-day low flow at 2- and 20-year recurrence intervals) at ungaged sites on streams could not be estimated adequately by regression methods. To estimate low-flow characteristics, discharge measurements of low flow must be correlated with concurrent flow at suitable continuous-record index stations where similar hydrologic conditions prevail.

The existing surface-water data network does not provide detailed hydrologic data. Detailed hydrologic data could be interpreted to identify flood-prone areas and evaluate the water-supply potential of minor streams and canals in the area. The existing streamflow-data network could be modified to include:

1. An expansion of the existing streamflow-data network.--Gaging stations could be installed on minor streams and maintained until correlations with nearby index stations are adequate to define streamflow characteristics assuming there is no change in flow regime at either site (fig. 35 and table 10). Stations where streamflow may become regulated or substantially altered because of land-use changes could be maintained to provide data for current-use and long-term trends. Types of data collected would include stage and discharge measurements (continuous), water-quality sampling (periodic and daily at selected sites), drainage basin characteristics, and land use.

2. A low-flow partial-record network.--The network could include stations used for measurement in the $1960^{\prime} \mathrm{s}$, stations on streams where projected land-use changes will occur, and at existing or potential impoundment sites. The low-flow partial-record sites would be continued for 3 or 4 years until a correlation can be made with nearby index stations. Water-quality data could also be collected periodically.

3. Expansion of the crest-stage, partia1-record network.--Stations could be located on streams or canals in rural areas that are not expected to change in 10 to 20 years or areas of existing urbanization. The data obtained would improve regional flood-frequency relations developed for west-central Florida that have limited application in the study area. The improvement would be in extending the flood-frequency 


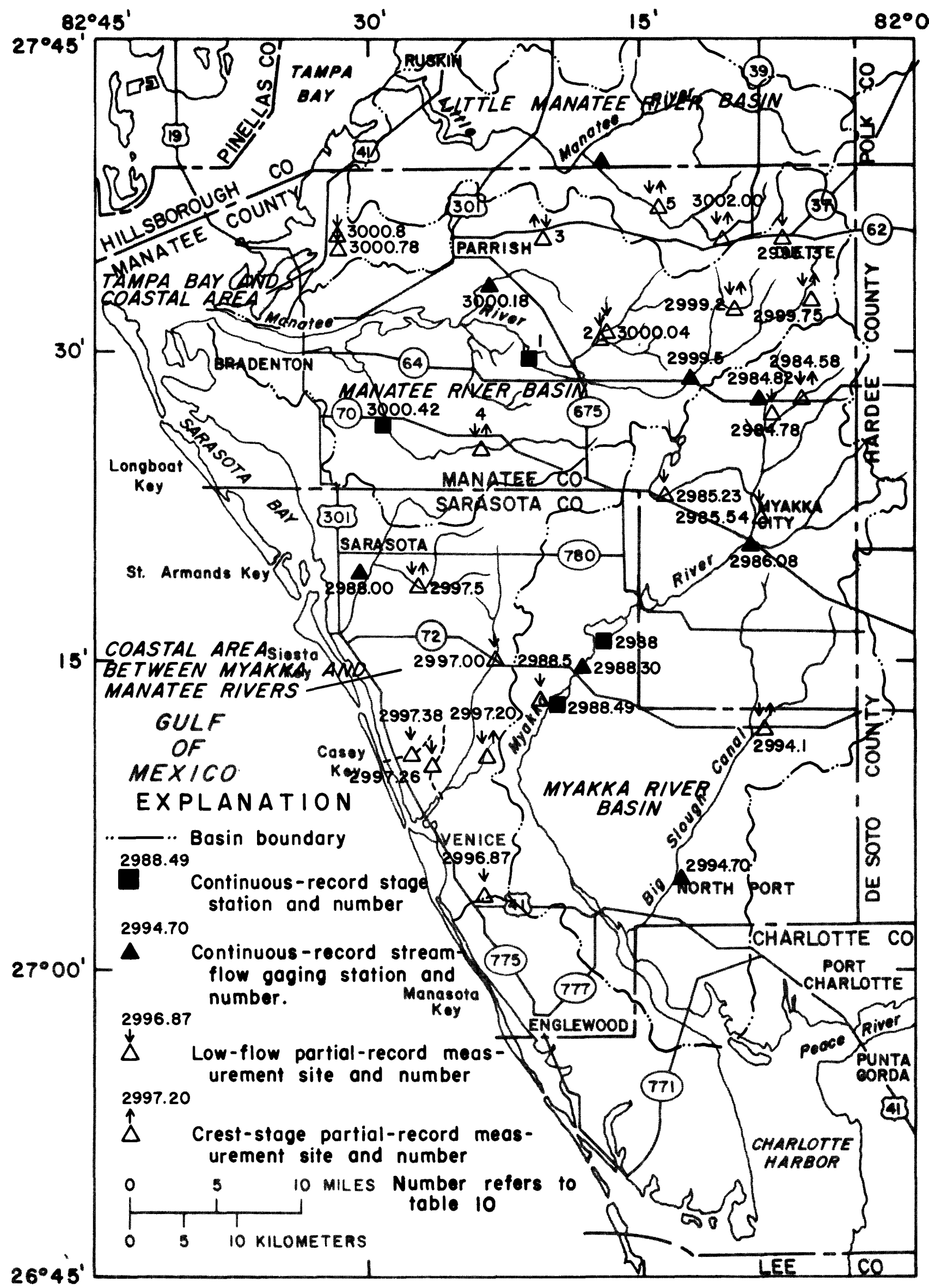

Figure 35.--Proposed surface-water data-collection network. 
relation to small rural and urban watersheds. Crest-stage gages would be operated 10 to 15 years. The information may be used by local governmental agencies to delineate flood-prone areas and to aid in flood-plain management. The expanded network could also incorporate urban-runoff monitoring sites to provide base-line or long-term data.

4. Collection of required data for future modeling of regulated stream systems.--The existing gaging station, Ward Lake near Bradenton on the Braden River, could be upgraded to a continuous stage-discharge station. A gaging station could be installed on Lake Manatee Reservoir. Modeling of Ward Lake and Lake Manatee would enable watersupply managers to simulate reservoir operations to optimize the water-supply potential of the reservoirs.

\section{Ground Water}

A ground-water data network consists of observation wells open to selected water-bearing zones. Water levels are measured continuously or periodically, and water samples are collected periodically for chemical analysis. Concurrent programs usually consist of well inventory, water-use inventory, and geologic and geophysical logging of wells or test holes.

Routinely collected ground-water data are generally for monitoring seasonal and long-term fluctuations of water tables and of the potentiometric surface of the Floridan aquifer. Other types of data for current use, planning and design, long-term trends, and hydrologic environment, such as water quality and hydrologic properties, are mainly specific to a site or area. These data are usually generated by special hydrologic studies.

The existing data network monitors the Floridan aquifer. Continuous and periodic water-level measurements are made on numerous observation wells. Most wells are privately owned and constructed with tens to hundreds of feet of open hole to one or more water-bearing zones. Thus, in some areas, the data represent composite water levels. Because most wells are privately owned, their use as observation wells may be temporary.

Projected declines in the potentiometric surface of the Floridan aquifer of about 30 feet from May 1976 to May 2000 and 20 feet from November 1976 to October 2000 indicate a need for a long-term data network.

Under the existing network little hydrologic data are collected on the surficial aquifer or intermediate aquifers. A well network for monitoring seasonal and long-term fluctuations of the surficial and intermediate aquifers water-levels is desirable because of increasing withdrawals of water from the aquifers.

Site-specific data, including water-level measurements and water-quality analyses, are collected in well-field areas and at a landfill operation in Venice. Chemical and radiochemical data are collected from selected water-bearing zones and aquifers in Sarasota County. A ground-water quality network to monitor longterm changes within the Basin does not exist. Some water-quality data are now provided by hydrologic investigations by the U.S. Geological Survey, other federal and local governmental agencies, and private industry. The data, however, may have little transfer value for the entire Basin. 
Table 10.--Proposed surface-water data-collection network

\begin{tabular}{c|c|c|c|c|c}
$\begin{array}{c}\text { Map } \\
\text { number } \\
\text { fig. 35) }\end{array}$ & $\begin{array}{c}\text { Station } \\
\text { name }\end{array}$ & $\begin{array}{c}\text { Latitude- } \\
\text { longitude }\end{array}$ & $\begin{array}{c}\text { Drain- } \\
\text { age } \\
\text { area } \\
\left(\mathrm{mi}^{2}\right)\end{array}$ & Type of data $\underline{1 /}$ & Remarks \\
\hline
\end{tabular}

\section{CONTINUOUS-RECORD GAGING STATIONS}

Myakka River Basin

\begin{tabular}{|c|c|c|c|c|c|}
\hline 02298492 & $\begin{array}{l}\text { Johnson Creek } \\
\text { near Myakka } \\
\text { Head }\end{array}$ & $\begin{array}{l}272734- \\
0820849\end{array}$ & 3.18 & $\begin{array}{l}\text { Planning and } \\
\text { design } \\
\text { Natural flow }\end{array}$ & $\begin{array}{l}\text { Existing } \\
\text { crest-st }\end{array}$ \\
\hline 02298608 & $\begin{array}{l}\text { Myakka River at } \\
\text { Myakka City }\end{array}$ & $\begin{array}{l}272047- \\
0820917\end{array}$ & 125 & $\begin{array}{l}\text { Planning and } \\
\text { design } \\
\text { Natural flow }\end{array}$ & Existing \\
\hline 02298800 & $\begin{array}{l}\text { Upper Myakka } \\
\text { Lake near } \\
\text { Sarasota }\end{array}$ & $\begin{array}{l}271550- \\
0821720\end{array}$ & 210 & Current & Proposed \\
\hline 02298830 & $\begin{array}{l}\text { Myakka River } \\
\text { near Sarasota }\end{array}$ & $\begin{array}{l}271425- \\
0821850\end{array}$ & 229 & $\begin{array}{l}\text { Long-term } \\
\text { trends }\end{array}$ & Existing \\
\hline 02298849 & $\begin{array}{l}\text { Lower Myakka } \\
\text { Lake near } \\
\text { Sarasota }\end{array}$ & $\begin{array}{l}271305- \\
0822000\end{array}$ & 240 & Current & Proposed \\
\hline 02299470 & $\begin{array}{l}\text { Big Slough Canal } \\
\text { near Murdock }\end{array}$ & $\begin{array}{l}270415- \\
0821305\end{array}$ & 87.5 & $\begin{array}{l}\text { Planning and } \\
\text { design } \\
\text { Natural flow }\end{array}$ & Proposed \\
\hline
\end{tabular}

Coastal Area Between Myakka and Manatee Rivers

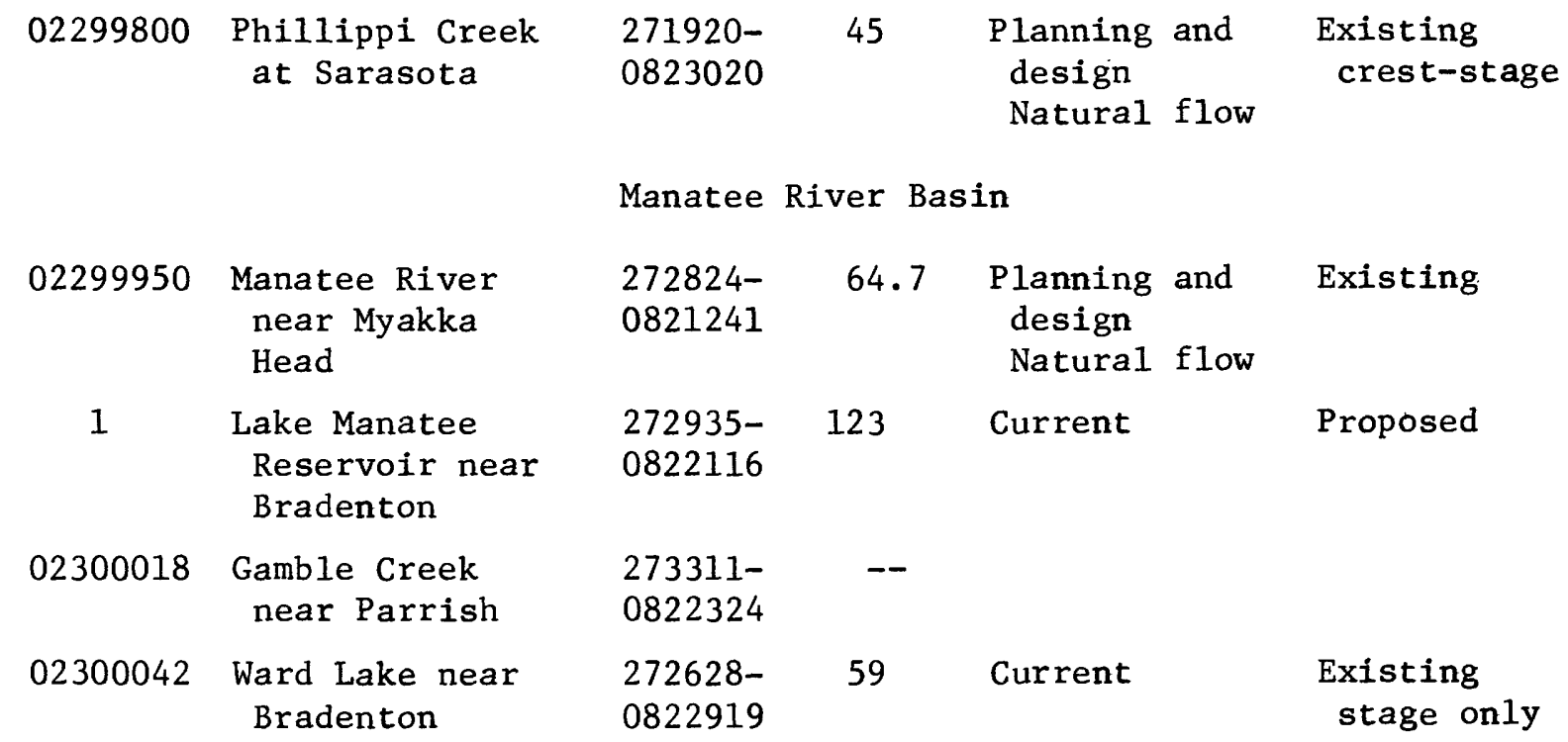

1/ Type of data listed in table 9. 
Table 10.--Proposed surface-water data-collection network--Continued

\begin{tabular}{c|c|c|c|c|c}
\hline $\begin{array}{c}\text { Map } \\
\text { number } \\
\text { fee }\end{array}$ & $\begin{array}{c}\text { Station } \\
\text { name }\end{array}$ & $\begin{array}{c}\text { Latitude- } \\
\text { longitude }\end{array}$ & $\begin{array}{c}\text { Drain- } \\
\text { age } \\
\text { area } \\
\left(\mathrm{mi}^{2}\right)\end{array}$ & Type of data $1 /$ & Remarks \\
\hline
\end{tabular}

CONTINUOUS-RECORD GAGING STATIONS--Continued

Little Manatee River Basin

\begin{tabular}{|c|c|c|c|c|c|}
\hline \multirow[t]{2}{*}{02300300} & $\begin{array}{l}\text { South Fork } \\
\text { Little Manatee }\end{array}$ & $\begin{array}{l}273857- \\
0821740\end{array}$ & 38 & $\begin{array}{l}\text { Planning and } \\
\text { design } \\
\text { Natural flow }\end{array}$ & \multirow[t]{2}{*}{ Proposed } \\
\hline & \multicolumn{4}{|c|}{ CREST-STAGE, PARTIAL-RECORD STATIONS } & \\
\hline 02298458 & $\begin{array}{l}\text { Myakka River } \\
\text { near Myakka } \\
\text { Head }\end{array}$ & $\begin{array}{l}272735- \\
0820640\end{array}$ & 10.08 & $\begin{array}{l}\text { Planning and } \\
\text { design } \\
\text { Natural flow } \\
\text { Flood fre- } \\
\text { quency }\end{array}$ & $\begin{array}{l}\text { Also low-flow, } \\
\text { partial-rec- } \\
\text { ord site }\end{array}$ \\
\hline 02299410 & $\begin{array}{l}\text { Big Slough Canal } \\
\text { near Myakka City }\end{array}$ & $\begin{array}{l}271135- \\
0820840\end{array}$ & 53 & $\begin{array}{l}\text { Planning and } \\
\text { design } \\
\text { Natural flow } \\
\text { Flood fre- } \\
\text { quency }\end{array}$ & $\begin{array}{l}\text { Also low-flow, } \\
\text { partial-rec- } \\
\text { ord site }\end{array}$ \\
\hline
\end{tabular}

Coastal Area Between Myakka and Manatee Rivers

\begin{tabular}{|c|c|c|c|c|c|}
\hline 02299720 & $\begin{array}{l}\text { Cow Pen Slough } \\
\text { near Laurel }\end{array}$ & $\begin{array}{l}271015- \\
0822340\end{array}$ & 56 & $\begin{array}{l}\text { Planning and } \\
\text { design } \\
\text { Natural flow } \\
\text { Flood fre- } \\
\text { quency }\end{array}$ & $\begin{array}{l}\text { Also low-flow, } \\
\text { partial-rec- } \\
\text { ord site }\end{array}$ \\
\hline \multirow[t]{2}{*}{02299750} & $\begin{array}{c}\text { Phillippi Creek } \\
\text { near Sarasota }\end{array}$ & $\begin{array}{l}271830- \\
0822706\end{array}$ & 24 & $\begin{array}{l}\text { Planning and } \\
\text { design } \\
\text { Natural flow } \\
\text { Flood fre- } \\
\text { quency }\end{array}$ & $\begin{array}{l}\text { Also low-flow, } \\
\text { partial-rec- } \\
\text { ord site }\end{array}$ \\
\hline & & \multicolumn{3}{|c|}{ Manatee River Basin } & \\
\hline 02299920 & $\begin{array}{l}\text { North Fork Mana- } \\
\text { tee River near } \\
\text { Myakka City }\end{array}$ & $\begin{array}{l}273150- \\
0821019\end{array}$ & 16.2 & $\begin{array}{l}\text { Planning and } \\
\text { design } \\
\text { Natural flow } \\
\text { Flood fre- } \\
\text { quency }\end{array}$ & $\begin{array}{l}\text { Low-flow, par- } \\
\text { tial-record } \\
\text { site }\end{array}$ \\
\hline 02299975 & $\begin{array}{l}\text { East Fork Mana- } \\
\text { tee River near } \\
\text { Myakka City }\end{array}$ & $\begin{array}{l}271319- \\
0820614\end{array}$ & 11.4 & $\begin{array}{l}\text { Planning and } \\
\text { design } \\
\text { Natural flow } \\
\text { Flood fre- } \\
\text { quency }\end{array}$ & $\begin{array}{l}\text { Low-flow, par- } \\
\text { tial-record } \\
\text { site }\end{array}$ \\
\hline 3 & $\begin{array}{l}\text { Gambles Creek } \\
\text { (Wimauma) }\end{array}$ & $\begin{array}{l}273535- \\
0822017\end{array}$ & -- & $\begin{array}{l}\text { Planning and } \\
\text { design } \\
\text { Natural flow } \\
\text { Flood fre- } \\
\text { quency }\end{array}$ & $\begin{array}{l}\text { Low-flow, par- } \\
\text { tial-record } \\
\text { site }\end{array}$ \\
\hline
\end{tabular}


Table 10.--Proposed surface-water data-collection network--Continued

\begin{tabular}{|c|c|c|c|c|c|}
\hline $\begin{array}{l}\text { Map } \\
\text { number } \\
\text { (see } \\
\text { fig. 35) }\end{array}$ & $\begin{array}{l}\text { Station } \\
\text { name }\end{array}$ & $\begin{array}{l}\text { Latitude- } \\
\text { longitude }\end{array}$ & $\begin{array}{l}\text { Drain- } \\
\text { age } \\
\text { area } \\
\left(\mathrm{mi}^{2}\right)\end{array}$ & Type of data $1 /$ & Remarks \\
\hline & $\begin{array}{r}\text { CREST-STAGE, } \\
\text { Manat }\end{array}$ & \multicolumn{4}{|c|}{ PARTIAL-RECORD STATIONS--Continued } \\
\hline 4 & $\begin{array}{l}\text { Braden River } \\
\text { (Lorraine) }\end{array}$ & $\begin{array}{l}272503- \\
0822358\end{array}$ & -- & $\begin{array}{l}\text { Planning and } \\
\text { design } \\
\text { Natural flow } \\
\text { Flood fre- } \\
\text { quency }\end{array}$ & $\begin{array}{l}\text { Low-flow, par- } \\
\text { tial-record } \\
\text { site }\end{array}$ \\
\hline \multicolumn{6}{|c|}{ Little Manatee River Basin } \\
\hline 02300200 & $\begin{array}{l}\text { South Fork Little } \\
\text { Manatee River } \\
\text { near Duette }\end{array}$ & $\begin{array}{l}273525- \\
0821057\end{array}$ & 9.4 & $\begin{array}{l}\text { Planning and } \\
\text { design } \\
\text { Natural flow } \\
\text { Flood fre- } \\
\text { quency }\end{array}$ & $\begin{array}{l}\text { Low-flow, par- } \\
\text { tial-record } \\
\text { site }\end{array}$ \\
\hline 5 & $\begin{array}{l}\text { South Fork Little } \\
\text { Manatee River } \\
\text { (Parrish) }\end{array}$ & $\begin{array}{l}273640- \\
0821421\end{array}$ & -- & $\begin{array}{l}\text { Planning and } \\
\text { design } \\
\text { Natural flow } \\
\text { Flood fre- } \\
\text { quency }\end{array}$ & Proposed \\
\hline \multirow{2}{*}{\multicolumn{6}{|c|}{$\begin{array}{c}\text { LOW-FLOW, PARTIAL-RECORD ST } \\
\text { Myakka River Basin }\end{array}$}} \\
\hline & & & ver Basi & & \\
\hline 02298458 & $\begin{array}{l}\text { Myakka River near } \\
\text { Myakka Head }\end{array}$ & $\begin{array}{l}272735- \\
0820640\end{array}$ & 10.8 & $\begin{array}{l}\text { Planning and } \\
\text { design } \\
\text { Natural flow } \\
\text { Low-flow } \\
\text { frequency }\end{array}$ & \\
\hline 02298478 & $\begin{array}{l}\text { Wingate Creek } \\
\text { near Myakka City }\end{array}$ & $\begin{array}{l}272734- \\
0820820\end{array}$ & 8.47 & $\begin{array}{l}\text { Planning and } \\
\text { design } \\
\text { Natural flow } \\
\text { Low-flow } \\
\text { frequency }\end{array}$ & \\
\hline 02298523 & $\begin{array}{l}\text { Ogleby Creek near } \\
\text { Myakka City }\end{array}$ & $\begin{array}{l}272247- \\
0821408\end{array}$ & 11 & $\begin{array}{l}\text { Planning and } \\
\text { design } \\
\text { Natural flow } \\
\text { Low-flow } \\
\text { frequency }\end{array}$ & \\
\hline 02298554 & $\begin{array}{l}\text { Myakka River near } \\
\text { Myakka City }\end{array}$ & $\begin{array}{l}272157- \\
0820858\end{array}$ & 87 & $\begin{array}{l}\text { Planning and } \\
\text { design } \\
\text { Natural flow } \\
\text { Low-flow } \\
\text { frequency }\end{array}$ & \\
\hline
\end{tabular}


Table 10.--Proposed surface-water data-collection network--Continued

\begin{tabular}{|c|c|c|c|c|c|}
\hline $\begin{array}{l}\text { Map } \\
\text { number } \\
\text { (see } \\
\text { fig. 35) }\end{array}$ & $\begin{array}{l}\text { Station } \\
\text { name }\end{array}$ & $\begin{array}{l}\text { Latitude- } \\
\text { longitude }\end{array}$ & $\begin{array}{l}\text { Drain- } \\
\text { age } \\
\text { area } \\
\left(\mathrm{mi}^{2}\right)\end{array}$ & Type of data ${ }^{1 /}$ & Remarks \\
\hline
\end{tabular}

LOW-FLOW, PARTIAL-RECORD STATIONS--Continued

Coastal Area Between Myakka and Manatee Rivers

02299687

Alligator Creek near Woodmere

02299700 Cow Pen Slough near Bee Ridge

02299720 Cow Pen Slough near Laurel

02299726 Fox Creek near Laure1

02299738 South Creek near Osprey

271032-

0822730

2709540822543

2710150822340

2714560822310

38

Natural flow
Low-flow frequency

56

(1)

12

(1)

Planning and design Natural flow Low-flow frequency

Planning and design Natural flow Low-flow frequency

\subsection{Planning and} design Natural flow Low-flow frequency

\section{Phillippi Creek} near Sarasota

271830 0822706
Planning and design Natural flow Low-flow frequency

Manatee River Basin

02299913 North Fork Mana-

273523-

tee River at

0820740

Duette

02299920 North Fork Mana-

273150tee River near Myakka City

0821019

16.2 Planning and design Natural flow

Low-flow frequency

02299975 East Fork Mana-

271319tee River near 0820614

11.4 Planning and design Natural flow Low-flow frequency 
Table 10.--Proposed surface-water data-collection network--Continued

\begin{tabular}{|c|c|c|c|c|c|}
\hline $\begin{array}{l}\text { Map } \\
\text { number } \\
\text { (see } \\
\text { fig. 35) }\end{array}$ & $\begin{array}{l}\text { Station } \\
\text { name }\end{array}$ & $\begin{array}{l}\text { Latitude- } \\
\text { longitude }\end{array}$ & $\begin{array}{l}\text { Drain- } \\
\text { age } \\
\text { area } \\
\left(m i^{2}\right)\end{array}$ & Type of data $1 /$ & Remarks \\
\hline \multicolumn{6}{|c|}{$\begin{array}{c}\text { LOW-FLOW, PARTIAL-RECORD STATIONS--Continued } \\
\text { Manatee River Basin--Continued }\end{array}$} \\
\hline 02300004 & $\begin{array}{l}\text { Gilley Creek near } \\
\text { Rye }\end{array}$ & $\begin{array}{l}273041- \\
0821715\end{array}$ & 10.2 & $\begin{array}{l}\text { Planning and } \\
\text { design } \\
\text { Natural flow } \\
\text { Low-flow } \\
\text { frequency }\end{array}$ & \\
\hline 2 & $\begin{array}{l}\text { Gilley Creek } \\
\text { (Oak Knol1) }\end{array}$ & $\begin{array}{l}273041- \\
0820717\end{array}$ & -- & $\begin{array}{l}\text { Planning and } \\
\text { design } \\
\text { Natural flow } \\
\text { Low-flow } \\
\text { frequency }\end{array}$ & \\
\hline 3 & $\begin{array}{l}\text { Gambles Creek } \\
\text { (Wimauma) }\end{array}$ & $\begin{array}{l}273535- \\
0822017\end{array}$ & - & $\begin{array}{l}\text { Planning and } \\
\text { design } \\
\text { Natural flow } \\
\text { Low-flow } \\
\text { frequency }\end{array}$ & \\
\hline 4 & $\begin{array}{l}\text { Braden River } \\
\text { (Lorraine) }\end{array}$ & $\begin{array}{l}272503- \\
0822358\end{array}$ & -- & $\begin{array}{l}\text { Planning and } \\
\text { design flow } \\
\text { Natural flow } \\
\text { Low-flow } \\
\text { frequency }\end{array}$ & \\
\hline \multicolumn{6}{|c|}{ Little Manatee River Basin } \\
\hline 02300200 & $\begin{array}{l}\text { South Fork Little } \\
\text { Manatee River } \\
\text { near Duette }\end{array}$ & $\begin{array}{l}273525- \\
0821057\end{array}$ & 9.4 & $\begin{array}{l}\text { Planning and } \\
\text { design } \\
\text { Natural flow } \\
\text { Low-flow } \\
\text { frequency }\end{array}$ & $\begin{array}{l}\text { Crest-stage, } \\
\text { partial-rec- } \\
\text { ord site }\end{array}$ \\
\hline 5 & $\begin{array}{l}\text { South Fork Little } \\
\text { Manatee River } \\
\text { (Parrish) }\end{array}$ & $\begin{array}{l}273640- \\
0821421\end{array}$ & - & $\begin{array}{l}\text { Planning and } \\
\text { design } \\
\text { Natural flow } \\
\text { Low-flow } \\
\text { frequency }\end{array}$ & \\
\hline \multicolumn{6}{|c|}{ Tampa Bay and Coastal Areas } \\
\hline 02300078 & $\begin{array}{l}\text { Frog Creek near } \\
\text { Terra Ceia }\end{array}$ & $\begin{array}{l}273450- \\
0823139\end{array}$ & & $\begin{array}{l}\text { Planning and } \\
\text { design } \\
\text { Natural flow } \\
\text { Low-flow } \\
\text { frequency }\end{array}$ & \\
\hline 02300080 & $\begin{array}{l}\text { Cabbage Slough } \\
\text { near Terra Ceia }\end{array}$ & $\begin{array}{l}273517- \\
0823159\end{array}$ & & $\begin{array}{l}\text { Planning and } \\
\text { design } \\
\text { Natural flow } \\
\text { Low-flow } \\
\text { frequency }\end{array}$ & \\
\hline
\end{tabular}


Development of the regional observation and monitor-well program (ROMP), started in 1974, by the Southwest Florida Water Management District provides detailed hydrologic data on a systematic basis. When completed, the monitoring program should provide most of the data necessary to define the groundwater system.

Figure 32 shows the location and status of ROMP sites in the Basin as of 1978. About 50 percent of the sites should be completed by 1982 . Figure 15 shows the projected decline in the potentiometric surface from May 1976 to May 2000. The regional plan provides adequate coverage of areas where the decline is greater than 5 feet.

Until ROMP is fully implemented, the existing ground-water data network could be modified as follows:

1. An expanded network of observation wells in the surficial aquifer, intermediate aquifers, and Floridan aquifer for continuous and periodic water-level measurements and periodic water-quality sampling could be established. A reasonable coverage of area aquifers would require about 10 nests of observation wells. Continuous records collected at selected sites would allow for monitoring seasonal water-level fluctuations. The location, depth, and type of observation wells could augment planned wells of the regional network. Concurrently, geologic and geophysical data, well inventory, and water-use inventory could be provided.

2. Observation wells operated and maintained by private industry and local governmental agencies could be evaluated for inclusion into the data network. Data previously collected could be evaluated and, where applicable, entered into computer storage.

\section{SUMMARY}

The hydropolitical Manasota Basin, Southwest Florida Water Management District, consists of Manatee and Sarasota Counties in southwest Florida. The Basin borders the Gulf of Mexico and is about 1,300 $\mathrm{mi}^{2}$ in size. Rangeland and agricultural land comprise about 72 percent of the Basin. Projected land-use changes by the year 2000 indicate slight decreases in rangeland and agricultural 1and and a substantial increase in urban land. An increase in strip mines from proposed phosphate mining in eastern Manatee County is also projected.

The source of all freshwater in the Manasota Basin is from rainfall on or adjacent to the Basin. The average annual rainfall is about 54 inches with about 60 percent of the rainfall occurring from June through September. The dry season generally occurs from October into May, which coincides with the fall and winter-spring growing seasons. Evapotranspiration is about 39 inches per year.

The Myakka and Manatee Rivers are the two major streams in the area. The Little Manatee and Peace Rivers drain parts of the Basin. Numerous small coastal streams originate within several miles of the coast and flow into bays and estuaries. Annual runoff in the gaged areas of the basin ranges from about 13 to 17 inches per year. 
The flow-duration curve of Myakka River near Sarasota has a steep slope, indicating highly variable flow. Flow-duration curves for the Manatee River near Bradenton and the Little Manatee River near Wimauma generally flatten out at their lower end, indicating release of ground-water for storage. Flow-duration curves for streams in the area generally flatten out at their upper end, indicating detention and slow release of water from storage in numerous lakes and swamps.

Streamflow in the upland areas diminishes rapidly at the end of the rainy season and approaches zero during extended periods of little or no rainfall. Extended periods of low flow are common in the upper reaches of streams.

The principal natural lakes in the basin are the Upper and Lower Myakka Lakes. Both lakes occupy shallow depressions and have a total storage of about $1,500 \mathrm{Mgal}$. The two principal springs in the area are Warm Salt and Little Salt Springs. Both discharge highly mineralized water.

The surface water is generally of good quality except in tidally affected and coastal areas where the streams and canals are usually saline. The quality varies seasonally. During the wet season, streamflow is mainly surface runoff; dissolved solids concentrations and hardness are minimum; and the color of the water is maximum. During the dry season, when the base flow of streams is maintained by ground-water discharge, dissolved solids concentrations and hardness increase and color of the water decreases. The chemical type of surface water at low flow ranges from a calcium and magnesium bicarbonate type in the middle and upper reaches of streams to a sodium chloride or calcium and magnesium sulfate type in coastal and low-lying areas.

As of 1978, the Big Slough Canal at North Port, the Manatee River at Lake Manatee Reservoir, the Braden River at Ward Lake, and the Little Manatee River in northern Manatee County were used for water supply. The combined average diversion is estimated to be about $40 \mathrm{Mgal} / \mathrm{d}$. There are additional sites on streams and two lakes that are suitable for impoundment for surface-water supply.

The Manasota Basin is underlain by a thick sequence of sedimentary rocks whose lithology and structure control the occurrence and movement of ground water. The hydrogeologic units are primarily the (1) surficial aquifer, (2) intermediate aquifers and confining beds, (3) Floridan aquifer, and (4) subFloridan confining unit.

The potentiometric surface of the Floridan aquifer varies seasonally. In May 1975, during a period of low water levels, the potentiometric surfaces ranged from about 10 feet below sea level to about 40 feet above sea level. The map of the potentiometric surface in May 1977 shows little change from 1975 and may indicate the aquifer is approaching equilibrium between recharge and pumpage. The decline in the potentiometric surface from May 1969 to May 1975 ranged from less than 5 feet at the coast to about 40 feet in northeastern Manatee County.

In September 1977, during a period of high water levels, the potentiometric surface ranged from about 20 feet above sea level near the coast to about 40 feet above sea level in the east. Seasonal fluctuation (May to September) of the potentiometric surface in 1977 ranged from less than 5 feet to about 30 feet. 
The quality of ground water is generally good except in the western (coastal) and southern parts of the Basin where saltwater intrusion or flushing of residual seawater has been incomplete. The dissolved solids concentration of ground water generally increases with depth and areally from the northeast towards the west and south.

The quality of water in the surficial aquifer and intermediate aquifers is acceptable except near the coast and in tidally affected streams where it approaches that of seawater. The water in the Floridan aquifer is generally more mineralized than water from the surficial aquifer and intermediate aquifers. Water of good quality in the Floridan aquifer is generally limited to the northeast.

Concentrations of dissolved solids in the surficial aquifer and intermediate aquifers are generally less than $500 \mathrm{mg} / \mathrm{L}$ except in coastal areas where concentrations can exceed $5,000 \mathrm{mg} / \mathrm{L}$. In the Floridan aquifer, concentrations of dissolved solids exceed $500 \mathrm{mg} / \mathrm{L}$ in the western and southern parts of the Basin.

In the surficial aquifer and intermediate aquifers, concentrations of sulfate and chloride greater than $250 \mathrm{mg} / \mathrm{L}$ are limited to the coastal and southern areas. In the Floridan aquifer, concentrations of sulfate exceeded $250 \mathrm{mg} / \mathrm{L}$ except in the northeast; concentrations of chloride greater than $250 \mathrm{mg} / \mathrm{L}$ are generally limited to the coastal and extreme southern parts of the Basin.

The intermediate aquifers and Floridan aquifer are highly developed sources of water. The surficial aquifer is undeveloped as a source of water except near the coast and southern parts of the Basin where water from deeper aquifers is not potable. The intermediate aquifers are widely used in the south, where they furnish most of the water used for domestic, home irrigation, and public water supplies, and a minor source of water to most irrigation wells. The Floridan aquifer is a major source of ground water, primarily for agricultural irrigation.

In 1975, total water use in the Manasota Basin was about $118 \mathrm{Mga} / \mathrm{d}$. The major water use is for irrigation, an estimated $44 \mathrm{Mgal} / \mathrm{d}$ in 1975 . More than 90 percent of the irrigation water was from ground-water sources. Projected ground-water withdrawal for irrigation is about $52 \mathrm{Mgal} / \mathrm{d}$ by 2000 . The estimated water use for public supply was $30.3 \mathrm{Mgal} / \mathrm{d}$ in 1975 and is projected to increase to $120 \mathrm{Mgal} / \mathrm{d}$ by 2000 . By 1985, the projected water use for industrial supply (including proposed phosphate mining in Manatee County) is 34.4 Mgal/d.

The existing surface-water network consists of three continuous-record streamflow stations, one continuous-record stage (reservoir) station, and three crest-stage, partial-record stations. Currently, one streamflow station, Myakka River near Sarasota, and one discontinued station, Manatee River near Bradenton, have sufficient length of record (more than 20 years) to adequately define their streamflow characteristics. One additional streamflow station, Little Manatee River near Wimauma, a stream that drains part of the Basin, also has sufficient record.

Major land-use changes, such as phosphate mining, urbanization, stream impoundments, and diversion will change streamflow characteristics. Definition of such changes may require the collection of additional data. 
In 1978, the long-term, ground-water data network consisted of 40 wells equipped with continuous water-level recorders and 4 wells where water levels are measured bimonthly. Under various investigations, water levels in an additional 58 wells penetrating the Floridan aquifer were measured semiannually, and selected wells in the Venice-Englewood area were measured continuously or periodically. Observation wells in the Verna well field penetrate the surficial aquifer, intermediate aquifers, and Floridan aquifer. Wells in the Venice-Englewood area penetrate the surficial aquifer and intermediate aquifers.

The major emphasis of the ground-water network is directed towards the Floridan aquifer; little hydrologic data are collected on the surficial aquifer or intermediate aquifers. Most wells in the network are privately owned and may penetrate one or more aquifers or water-bearing zones. Data obtained from these wells may represent a composite of the various aquifers, and access to these wells may be only temporary.

A ground-water quality network is nonexistent. Current water-quality data are provided as a byproduct of hydrologic investigations by the U.S. Geological Survey, other federal and local governmental agencies, and private industry.

Development of ROMP by the Southwest Florida Water Management District provides detailed hydrologic data on a systematic basis. When completed, the monitoring program could provide most of the data necessary to define the groundwater system.

\section{SELECTED REFERENCES}

B1ack, Crow and Eidsness, Inc., April 1973, Engineering report on artificial recharge at Willow, Manatee County, Florida: Unpublished consultant's report prepared for Florida Power and Light Company, Miami, Florida, in files of the Southwest Florida Water Management District.

Buono, Anthony, Causseaux, K. W., and Moore, J. E., 1978, Summary of U.S. Geological Survey investigations and hydrologic conditions in the Southwest Florida Water Management District for 1977: U.S. Geological Survey Open-File Report 78-331, 88 p.

Buono, Anthony, and Rutledge, A. T., 1978, Configuration of the top of the Floridan aquifer, Southwest Florida Water Management District and adjacent areas: U.S. Geological Survey Water-Resources Investigations OpenFile Report 78-34, map.

Buono, Anthony, Spechler, R. M., Barr, G. L., and Wolansky, R. M., 1979, Generalized thickness of the confining bed overlying the Floridan aquifer, Southwest Florida Water Management District: U.S. Geological Survey Water-Resources Investigations Open-File Report 79-1171, map.

Cathcart, J. B., 1963, Economic Geology of the Chicora Quadrangle, Florida: U.S. Geological Survey Bulletin 1162-A, 66 p.

Cathcart, J. B., and McGreevy, L. J., 1959, Results of geologic exploration by core drilling, 1953, land-pebble phosphate district, Florida: U.S. Geological Survey Bulletin 1046-K, p. 221-298. 
Cherry, R. N., Stewart, J. W., and Mann, J. A., 1968, General hydrology of the middle gulf area, Florida: Florida Geological Survey Report of Investigations 56, $96 \mathrm{p}$.

Clark, W. E., 1964, Possibility of salt-water leakage from proposed Intracoastal Waterway near Venice, Florida, well field: Florida Geological Survey Report of Investigations $38,33 \mathrm{p}$.

Conover, C. S., and Leach, S. D., 1975, Drainage basins in Florida: Florida Bureau of Geology Map Series 72.

Cooke, C. W., 1945, Geology of Florida: Florida Geological Survey Bulletin $29,342 \mathrm{p}$.

Duerr, A. D., 1974, Hydrologic data from wells in southwest Hillsborough County, Florida, 1950-74: U.S. Geological Survey open-file report FL-74031, 53 p.

1975a, The potentiometric surface and water quality of the Floridan aquifer in southwest Hillsborough County, Florida, 1952-74: U.S. Geological Survey Water-Resources Investigations 50-75, map.

1975b, Water levels in wells that tap the Floridan aquifer in southwest Hillsborough County, Florida, May 1974 and May 1975: U.S. Geological Survey open-file report FL-75002, 52 p.

Ferguson, G. E., Lingham, C. W., Love, S. K., and Vernon, R. D., 1947, Springs of Florida: Florida Geological Survey Bulletin 31, 198 p.

Flippo, H. N., Jr., and Joyner, B. F., 1968, Low streamflow in the Myakka River basin area in Florida: Florida Geological Survey Report of Investigations $53,34 \mathrm{p}$.

Geraghty and Miller, Inc., 1977, Hydrologic effects of developing 15 MGD of water from the Floridan aquifer in the Pine Level area, DeSoto and Manatee Counties, Florida: Unpublished consultant's report for Phillips Petroleum Company, in files of the Southwest Florida Water Management District, 73 p.

Gomberg, D. N., 1975, Regional observation and monitor well program (ROMP): Purpose and Plan: Southwest Florida Water Management District, $44 \mathrm{p}$.

Hammett, K. M., Turner, J. F., Jr., and Murphy, W. R., Jr., 1978, Magnitude and frequency of flooding on the Myakka River, southwest Florida: U.S. Geological Survey Water-Resources Investigations 78-65, $40 \mathrm{p}$.

Healy, H. G., 1962, Piezometric surface of the Floridan aquifer in Florida, July 6-17, 1961: Florida Division of Geology Map Series 1.

1977, Public water supplies of selected municipalities in Florida, 1975: U.S. Geological Survey Water-Resources Investigations 77-53, 309 p.

Hem, J. D., 1970, Study and interpretation of the chemical characteristics of natural water: U.S. Geological Survey Water-Supply Paper 1473, 269 p.

Hickey, J. J., 1977, Hydrogeologic data for the McKay Creek waste-injection test site, Pinellas County, Florida: U.S. Geological Survey Open-File Report 77-802, $94 \cdot \mathrm{p}$.

Hughes, G. H., Hampton, E. R., and Tucker, D. F., 1971, Annual and seasonal rainfall in Florida: Florida Bureau of Geology Map Series 40.

Hutchinson, C. B., 1977, Appraisal of shallow ground-water resources and management alternatives in the upper Peace and eastern Alafia River basins, Florida: U.S. Geological Survey Water-Resources Investigations 77-124, $57 \mathrm{p}$. 
Hutchinson, C. B., and Wilson, W. E., 1974, Evaluation of a proposed connector well, northeastern DeSoto County, Florida: U.S. Geological Survey WaterResources Investigations 5-74, $41 \mathrm{p}$.

Irwin, G. A., and Hutchinson, C. B., 1976, Radium-226 reconnaissance water sampling of eight Florida counties, December 1974-January 1975: U.S. Geologica1 Survey Water-Resources Investigations 76-103, $16 \mathrm{p}$.

Joyner, B. F., and Sutcliffe, Horace, Jr., 1976, Water resources of Myakka River basin area, Florida: U.S. Geological Survey Water-Resources Investigations $76-58,87 \mathrm{p}$.

Kaufman, M. I., 1969 (revised 1975), Color of water in Florida streams and canals: Florida Bureau of Geology Map Series 35.

1972 (revised 1975), The chemical type of water in Florida streams: Florida Bureau of Geology Map Series 51 .

Kaufman, M. I., and Dion, N. P., 1967, Chemical character of water in the Floridan aquifer in southern Peace River basin, Florida, 1967: Florida Geological Survey Map Series 27.

1968, Ground-water resources data, Charlotte, DeSoto, and Hardee Counties, Florida: Florida Geological Survey Information Circular 53, 24 p.

Kenner, W. E., 1969 (revised 1975), Seasonal variations of streamflow in Florida, 1969: Florida Geological Survey Map Series 31.

Kenner, W. E., Hampton, E. R., and Conover, C. S., 1969 (revised 1975), Average flow of major streams in Florida: Florida Bureau of Geology Map Series 34.

Klein, Howard, 1971 (revised 1975), Depth to base of potable water in the Floridan aquifer: Florida Bureau of Geology Map Series 42.

Leach, S. D., 1977, Water-use inventory in Florida, 1975: U.S. Geological Survey Open-File Report 77-577, 90 p.

Lohman, S. W., 1972, Ground-water hydraulics: U.S. Geological Survey Professional Paper $708,70 \mathrm{p}$.

Matson, G. C., and Sanford, Samue1, 1913, Geology and ground waters of Florida: U.S. Geologica1 Survey Water-Supply Paper 319, 445 p.

Menke, G. C., Meredith, E. W., and Wetterha11, W. S., 1961, Water resources of Hillsborough County, Florida: Florida Geological Survey Report of Investigations 25, 101 p.

Michael Baker, Jr., Inc., May 1975, Surface water hydrology (DeSoto and Manatee Counties, Florida): Unpublished consultant's report prepared for Phillips Petroleum Company, in files of the Southwest Florida Water Management District.

Mills, L. R., and Laughlin, C. P., 1976, Potentiometric surface of the Floridan aquifer, May 1975, and change of the potentiometric surface, 1969 to 1975, Southwest Florida Water Management District and adjacent areas: U.S. Geological Survey Water-Resources Investigations 76-80, map.

Mills, L. R., Laughlin, C. P., and Parsons, D. C., 1976, Potentiometric surface of the Floridan aquifer, Southwest Florida Water Management District, September 1975: U.S. Geological Survey Open-File Report 76-003, map. 
National Academy of Sciences and National Academy of Engineering, 1973, Waterquality criteria, 1972: U.S. Environmental Protection Agency Report

EPA R3 73 033, 594 p.

P. E. LaMoreaux \& Associates, Inc., May 1974, Analysis of the surface water conditions of the Beker Property, Manatee County, Florida: Unpublished consultant's report prepared for Beker Industries Corporation, Natural Resources Division, Tampa, Fla., in files of the Southwest Florida Water Management District.

Parker, G. G., Ferguson, G. E., Love, S. K., and others, 1955, Water resources of southeastern Florida, with special reference to the geology and ground water of the Miami area: U.S. Geological Survey Water-Supply Paper 1255, 965 p.

Pascale, C. A., 1975, Estimated yield of fresh-water wells in Florida: Florida Bureau of Geology Map Series 70.

Peek, H. M., 1958a, Ground-water resources of Manatee County, Florida: Florida Geological Survey Report of Investigations 18, 99 p.

1958b, Record of wells in Manatee County, Florida: Florida Geological Survey Information Circular 19, 196 p.

1959a, Record of wells in the Ruskin area, Hillsborough County, Florida: Florida Geological Survey Information Circular 22, 85 p.

1959b, The artesian water of the Ruskin area of Hillsborough County, Florida: Florida Geological Survey Report of Investigations 21, $96 \mathrm{p}$.

Peek, H. M., and Anders, R. B., 1955, Interim report on the ground-water resources of Manatee County, Florida: Florida Geological Survey Information Circular 6, $38 \mathrm{p}$.

Phillips Petroleum Company, May, 1975, Development of Regional Impact Application for development approval phosphate mining DeSoto and Manatee Counties, Florida: Development of Regional Impact Statement.

Pride, R. W., 1970 (Second edition 1975), Estimated water use in Florida, 1965: Florida Bureau of Geology Map Series 36.

1973, Estimated water use in Florida, 1970: Florida Bureau of Geology Information Circular 83, $31 \mathrm{p}$.

Rabon, J. W., 1970, Evaluation of streamflow data program in Florida: U.S. Geological Survey open-file report FL-70008, $70 \mathrm{p}$.

Richard C. Fountain and Associates, 1975, An analysis of the hydrologic conditions of surface and ground water resources in the area of Beker Property in eastern Manatee County, Florida: Unpublished consultant's report prepared for Beker Phosphate Corporation, in files of the Southwest Florida Water Management District.

Rosenau, J. C., Faulkner, G. L., Hendry, C. W., and Hu11, R. W., 1977, Springs of Florida: Florida Bureau of Geology Bulletin 31 (revised), 461 p.

Rosenshein, J. S., and Hickey, J. J., 1977, Storage of treated sewage effluent and treated storm water in a saline aquifer: Ground Water Journal, v. 15, no. 4, p. 284-293. 
Ryder, P. D., Laughlin, C. P., and Mills, L. R., 1976, Potentiometric surface of the Floridan aquifer, Southwest Florida Water Management District, September 1976: U.S. Geological Survey Open-File Report 77-353, map.

1977, Potentiometric surface of the Floridan aquifer, Southwest Florida Water Management District, May 1977: U.S. Geological Survey Open-File Report 77-552, map.

Ryder, P. D., and Mills, L. R., 1977a, Water table in the surficial aquifer and potentiometric surface of the Floridan aquifer in selected well fields, May 1976: U.S. Geological Survey Open-File Report 77-257, map.

$1977 \mathrm{~b}$, Water table in the surficial aquifer and potentiometric surface of the Floridan aquifer in selected well fields, September 1976: U.S. Geological Survey Open-File Report 77-551, map.

1977c, Water table in the surficial aquifer and potentiometric surface of the Floridan aquifer in selected well fields, May 1977: U.S. Geological Survey Open-File Report 77-642, map.

1978, Water table in the surficial aquifer and potentiometric surface of the Floridan aquifer in selected well fields, September 1977: U.S. Geological Survey Open-File Report 78-311, map.

Ryder, P. D., Mills, L. R., and Woodham, W. M., 1978, Potentiometric surface of the Floridan aquifer, Southwest Florida Water Management District and adjacent areas, September 1977: U.S. Geological Survey Open-File Report 78-9, map.

Seijo, M. A., Giovannelli, R. F., and Turner, J. F., Jr., 1979, Regional floodfrequency relations for west-central Florida: U.S. Geological Survey WaterResources Investigations Open-File Report 79-1293, 41 p.

Sinclair, W. C., 1974, Hydrogeologic characteristics of the surficial aquifer in northwest Hillsborough County, Florida: Florida Bureau of Geology Information Circular 86, 98 p.

1977, Experimental study of artificial recharge alternatives in northwest Hillsborough County, Florida: U.S. Geological Survey Water-Resources Investigations 77-13, $52 \mathrm{p}$.

Smalley, Wellford and Nalvin, 1977, Manasota Literature Assessment Study: Consultant's report for Board of Sarasota County Commissioners, 120 p.

Smith and Gillespie Engineers, Inc., 1971, Engineers preliminary report on Braden River Water Supply for city of Bradenton, Florida: Consultant's report for city of Bradenton, $97 \mathrm{p}$.

Southwest Florida Water Management District, 1978, Water management plan-78: Southwest Florida Water Management District, Brooksville, Florida, 65 p.

Stewart, H. G., Jr., 1959, Interim report on the geology and ground-water resources of northwestern Polk County, Florida: Florida Geological Survey Information Circular 23, 93 p.

1966, Ground-water resources of Polk County: Florida Geological Survey Report of Investigations 44, $170 \mathrm{p}$.

Stewart, J. W., Laughlin, C. P., and Mil1s, L. R., 1976, Potentiometric surface of the Floridan aquifer, Southwest Florida Water Management District, May 1976: U.S. Geological Survey Open-File Report 76-004, map. 
Stewart, J. W., Mills, L. R., Knochenmus, D. D., and Faulkner, G. L., 1971, Potentiometric surface and areas of artesian flow, May 1969, and change of potentiometric surface, 1964 to 1969, Floridan aquifer, Southwest Florida Water Management District, Florida: U.S. Geological Survey Hydrologic Investigation Atlas $\mathrm{HA}-440$.

Stringfield, V. T., 1933a, Ground-water resources of Sarasota County, Florida, and exploration of artesian wells in Sarasota County, Florida: Florida Geological Survey, in 23rd-24th Annual Report, p. 131-227.

1933b, Ground-water investigation in Florida: Florida Geological Survey Bulletin 11, $33 \mathrm{p}$.

1936, Artesian water in the Florida peninsula: U.S. Geological Survey Water-Supply Paper 773-C, p. 115-195.

1966, Artesian water in Tertiary limestone in the southeastern states: U.S. Geological Survey Professional Paper 517, 226 p.

Sutcliffe, Horace, Jr., 1975, Appraisal of the water resources of Charlotte County, Florida: Florida Bureau of Geology Report of Investigations 78, $53 \mathrm{p}$.

Sutcliffe, Horace, Jr., and Joyner, B. F., 1968, Test well exploration in the Myakka River basin area, Florida: Florida Geological Survey Information Circular 56, 61 p.

Texas Instruments Incorporated, 1977a, Demography, economics, and cultural: U.S. Environmental Protection Agency, Central Florida Phosphate Industry Areawide Impact Assessment Program, v. 3.

1977b, Future 1and use: U.S. Environmental Protection Agency, Central Florida Phosphate Industry Areawide Impact Assessment Program, v. 10.

1978, Water: U.S. Environmental Protection Agency, Central Florida Phosphate Industry Areawide Impact Assessment Program, v. 5.

Toler, L. G., 1967, Fluoride in water in the Alafia and Peace River basins, Florida: Florida Geological Survey Report of Investigations 46,46 p.

U.S. Department of Agriculture, 1965, Water and related land resources, Florida west coast tributaries: U.S. Department of Agriculture unnumbered report, 103 p. with appendix.

U.S. Environmental Protection Agency, 1978, Draft areawide environmental impact statement, central Florida phosphate industry, $179 \mathrm{p}$.

1979, National secondary drinking water regulations: Federal Register, v. 44, no. 140, Thursday, July 19, 1979, p. 42196-42202.

U.S. Geological Survey, Surface water records of Florida, Volume 1, Streams: 1961, 1962, 1963, 1964.

Surface water records of Florida, Volume 2, Lakes: 1961, 1962, 1963, 1964.

Water resources data for Florida, Part 1, Surface water records, Volume 1, Streams: 1965.

Water resources data for Florida, Part 1, Surface water records, Volume 2, Lakes: 1965. 
U.S. Geological Survey, Water resources data for Florida, Part 1, Surface water records, Volume 1, Streams--northern and central Florida: 1966, 1967, 1968, 1969, 1970, 1971, 1972, 1973, 1974.

Water resources data for Florida, Part 1, Surface water records, Volume 2, Streams--southern Florida, Lake Okeechobee and the Everglades: 1966, 1967, 1968, 1969, 1970, 1971, 1972.

Water resources data for Florida, Part 1, Surface water records, Volume 3, Lakes: 1966, 1967, 1968, 1969, 1970, 1971, 1972, 1973, 1974.

Water resources data for Florida, Part 2, Water quality records: 1965, 1966, 1967, 1968, 1969, 1970, 1971, 1972, 1973, 1974.

Water resources data for Florida, Volume 3, west-central Florida, surface water, ground water, quality of water: 1975 .

Water resources data for Florida, Volume 3, southwest Florida, surface water, ground water, quality of water: 1976, 1977.

University of Florida, 1977, Florida statistical abstract, 1977: The University Presses of Florida, College of Business Administration, Bureau of Economics and Business Research, 597 p.

Van Bussum, L. G., 1974, UF's density prediction: The Tampa Tribune, July 12, 1974, p. 13B.

Vernon, R. O., and Puri, H. S., 1965, Geologic map of Florida: Florida Geological Survey Map Series 18.

Visher, F. N., and Hughes, G. H., 1969 (revised 1975), The difference in rainfall and potential evaporation in Florida: Florida Bureau of Geology Map Series 32.

White, W. A., 1970, The geomorphology of the Florida peninsula: Florida Bureau of Geology Bulletin 51, $164 \mathrm{p}$.

William F. Guyton and Associates, 1976a, Test hole geology: Unpublished consultant's report prepared for Swift Agricultural Chemicals Corporation, Manatee mine site, in files of the Southwest Florida Water Management District.

$1976 \mathrm{~b}$, Well inventory, irrigation well logging and well construction: Unpublished consultant's report prepared for Swift Agricultural Chemicals Corporation, Manatee mine site, in files of the Southwest Florida Water Management District.

1976c, Test hole geophysics and bore hole flow: Unpublished consultant's report prepared for Swift Agricultural Chemicals Corporation, Manatee mine site, in files of the Southwest Florida Water Management District.

1976d, Hydraulics and water quality (northeast Manatee County, Florida): Unpublished consultant's report for Swift Agricultural. Chemicals Corporation, Manatee mine site, in files of the Southwest Florida Water Management District.

Wilson, W. E., 1972, Hydrogeology of Florida's largest citrus grove: American Society of Civil Engineers, Irrigation and Drainage Division Speciality Conference proceedings, p. 293-307.

1975, Ground-water resources of DeSoto and Hardee Counties, Florida: Florida Bureau of Geology Report of Investigations 83, 102 p. 
Wilson, W. E., 1977, Simulated changes in ground-water levels resulting from proposed phosphate mining, west-central Florida--preliminary results: U.S. Geological Survey Open-File Report 77-882, 46 p.

Wilson, W. E. and Gerhart, J. M., 1979, Simulated effects of ground-water development on potentiometric surface of the Floridan aquifer, west-central Florida: U.S. Geological Survey Water-Resources Investigations Open-File Report 79-1271, 173 p.

Wolansky, R. M., Mills, L. R., and Woodham, W. M., 1978, Water table in the surficial aquifer and potentiometric surface of the Floridan aquifer in selected well fields, May 1978: U.S. Geological Survey Open-File Report 78-939, map. 



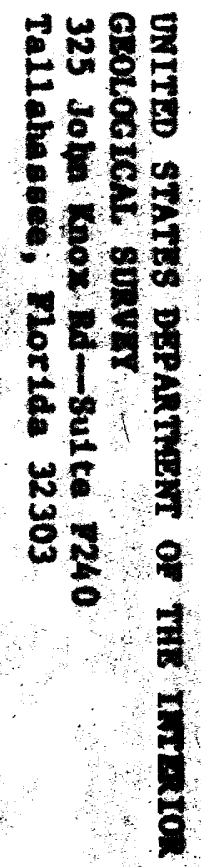

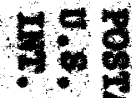

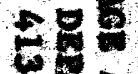

3

b

8

望

홍

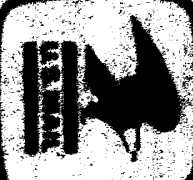

